$$
\begin{gathered}
\text { UNIVERSIDADE DE SÃO PAULO } \\
\text { ESCOLA DE COMUNICAÇÃO E ARTES }
\end{gathered}
$$

MARCELO EDUARDO PEREIRA SGRILLI

\author{
A dimensão sonora da televisão: \\ o percurso do som nas telenovelas da TV Globo
}


MARCELO EDUARDO PEREIRA SGRILLI

\title{
A dimensão sonora da televisão: o percurso do som nas telenovelas da TV Globo
}

\author{
Versão Corrigida \\ (Versão original disponível na Biblioteca da ECA/USP)
}

Dissertação apresentada ao Programa de Pós-graduação em Meios e Processos Audiovisuais para obtenção do título de Mestre em Ciências. Linha de pesquisa: Poéticas e Técnicas, Escola de Comunicação e Artes da Universidade de São Paulo.

Orientador: Prof. Dr. Eduardo Simões dos Santos Mendes

São Paulo

2017 
SGRILLI, M. E. P. A dimensão sonora da televisão: o percurso do som nas telenovelas da TV Globo. Dissertação apresentada ao Programa de Pós-graduação em Meios e Processos Audiovisuais para obtenção do título de Mestre em Ciências. Linha de pesquisa: Poéticas e Técnicas, Escola de Comunicação e Artes da Universidade de São Paulo.

Aprovado em:

Banca examinadora

Prof. Dr.

Instituição:

Julgamento:

Prof. Dr.

Instituição:

Julgamento:

Prof. Dr.

Instituição:

Julgamento: 


\section{AGRADECIMENTOS}

Ao Prof. Dr. Eduardo Simões dos Santos Mendes, por compartilhar o seu conhecimento e pela orientação serena que me guiou ao longo desse processo de formação.

Ao Prof. Dr. Eduardo Vicente e Prof. Dr. Fernando de Jesus Giraldo Salinas, pela participação na qualificação e pelos apontamentos que enriqueceram a pesquisa.

À Globo Universidade, pelo apoio a pesquisa.

Ao Juan Manuel Guadelis Crisafulli, que abriu caminhos para os diálogos com os profissionais da TV Globo e o acesso ao acervo da emissora.

Aos profissionais entrevistados, Aroldo Barros, Carlos Ronconi, Guerra Peixe Filho, Thanus Chalita e Rodrigo Meirelles, pela generosidade de compartilhar suas experiências.

Aos funcionários do Acervo Globo, pela atenção e esforço para atender as demandas dessa pesquisa.

Ao Paulo Roberto Ferreira, que antes mesmo do início dessa pesquisa, dedicou um dia de seu trabalho para me apresentar os processos da produção sonora da TV Globo.

À Haryanna Sgrilli, pela revisão do texto e sugestões que contribuíram para o melhor acabamento desse trabalho.

Aos meus pais, familiares e amigos, por todo apoio e carinho.

Em especial, à Thais, companheira incondicional que segurou as pontas durante todo o percurso. 


\title{
RESUMO
}

A presente dissertação propõe uma abordagem da televisão brasileira através de um diálogo com os estudos do som, tendo como objeto a dimensão sonora das telenovelas. O estudo procura mapear as principais transformações ocorridas no aparato técnico sonoro televisivo, bem como a evolução dos processos da produção do som no período de 1950 até o início do século XXI. Posteriormente, visando investigar as funções desempenhadas pelos elementos sonoros - vozes, ruídos e músicas - na construção da narrativa das telenovelas, este trabalho apresenta uma análise da trilha sonora de cinco telenovelas da TV Globo: Pecado Capital (1975), Roque Santeiro (1985), Renascer (1993), Senhora do Destino (2004) e Avenida Brasil (2012).

Palavras-chave: Som. Trilha sonora. Sonoplastia. Televisão. Telenovela. Teledramaturgia.

\begin{abstract}
This essay proposes an approach on Brazilian television through a dialogue with sound studies, having as object the soap operas' sound aspects. It intends to map the main changes that occurred on television's audio technical apparatus, as well as the evolution on the sound production processes from 1950 until the beginning of the twenty first century. Subsequently, this work aims to investigate the functions performed by the sound elements - dialogues, sound effects, music - on the development of soap opera narratives and presents an analysis of the soundtracks of five soap operas produced by TV Globo: Pecado Capital (1975), Roque Santeiro (1985), Renascer (1993), Senhora do Destino (2004) and Avenida Brasil (2012).
\end{abstract}

Keywords: Sound. Soundtrack. Sound Design. Television. Soap Opera. TV Drama. 


\section{LISTA DE FIGURAS}

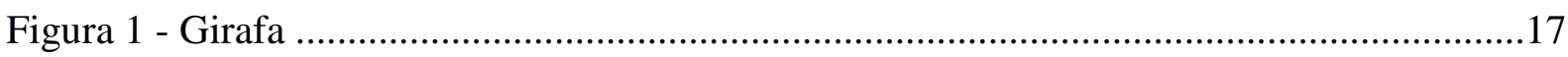

Figura 2 - Realização de cena em estúdio na TV Tupi ........................................................18

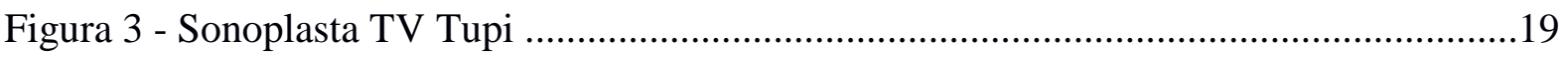

Figura 4 - Diagrama da varredura vertical do Quadruplex ................................................21

Figura 5 - Carretel com fita magnética de 2 polegadas ....................................................21

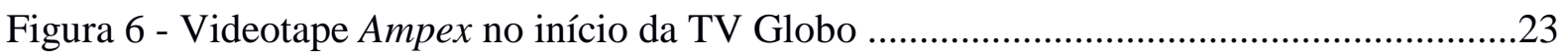

Figura 7 - Ampex VR-3000 durante a gravação da telenovela O Cafona, produzida pela TV Globo em 1971 ...................................................................26

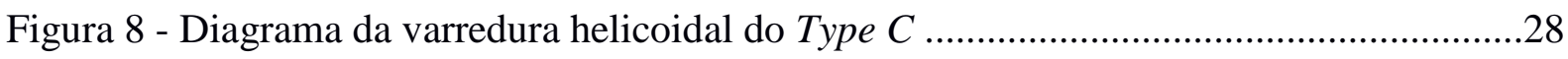

Figura 9 - Videotape Sony BVH-2000 utilizado pela TV Globo ........................................29

Figura 10 - Gravador de som Studer A-80 com oito pistas, similar ao que era utilizado na TV Globo ........................................................30 


\section{SUMÁRIO}

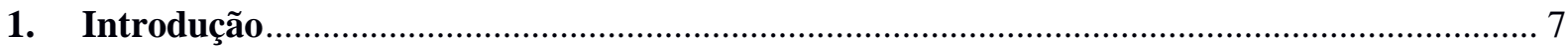

2. A evolução tecnológica e os processos da produção sonora .................................................. 14

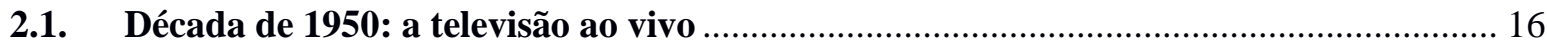

2.2. Década de 1960: a chegada do videotape ao Brasil .................................................... 21

2.3. Década de 1970: os equipamentos portáteis.................................................................. 25

2.4. Década de 1980: o novo formato de videotape e os gravadores de som multipista ....... 28

2.5. Década de 1990: a estereofonia e o início da digitalização ............................................. 33

2.6. Século XXI: a consolidação da digitalização............................................................... 35

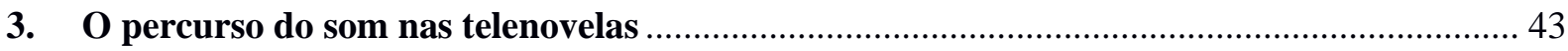

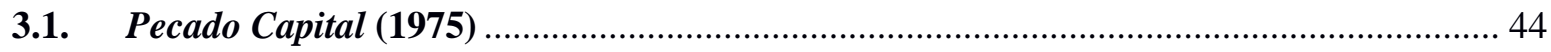

3.1.1. Sinopse

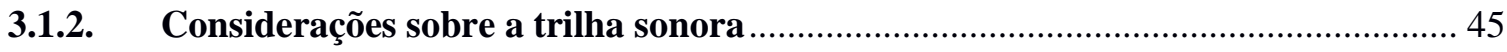

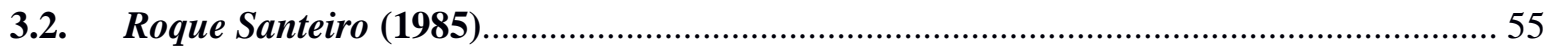

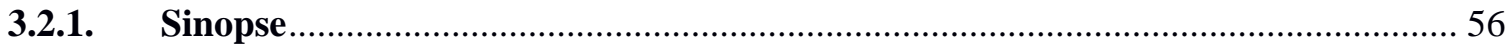

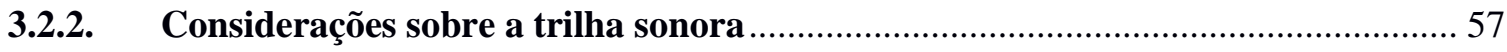

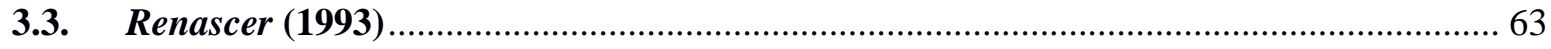

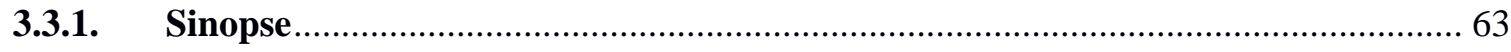

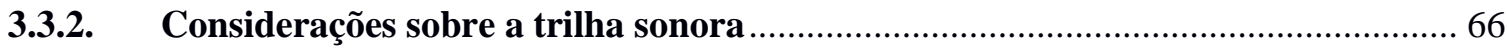

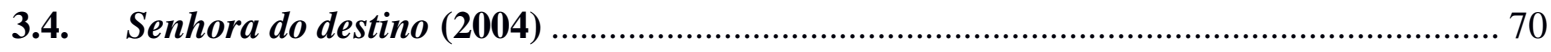

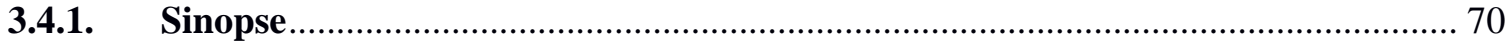

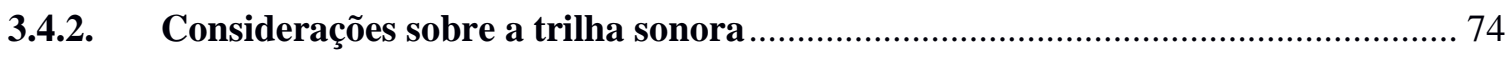

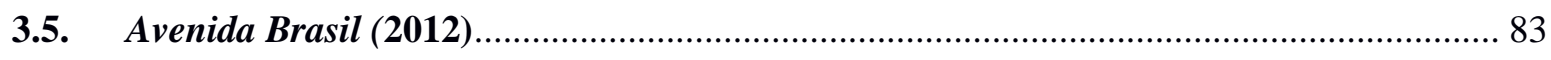

3.5.1. Sinopse

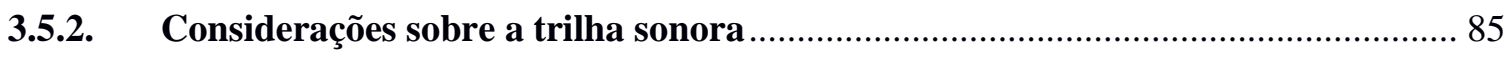

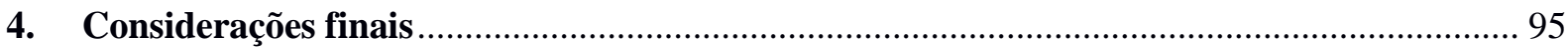

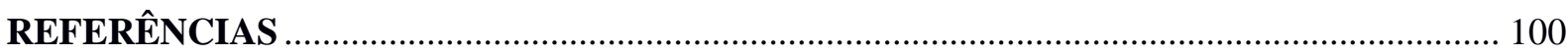

APÊNDICE A - Tabela pesquisas sobre o som na televisão ….............................................. 106

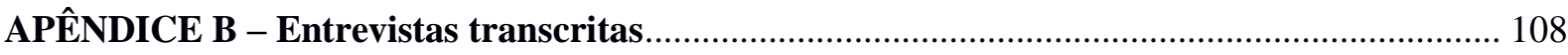




\section{Introdução}

A presente pesquisa propõe uma discussão sobre a televisão brasileira, tendo como eixo central a dimensão sonora das telenovelas. As motivações para a realização desse estudo remontam à própria trajetória deste pesquisador durante a graduação em Rádio e Televisão na Universidade Estadual Paulista (UNESP). Ao longo do processo de formação, a busca por esmiuçar o fazer televisivo, com foco na produção sonora, fez suscitar questões preponderantes sobre o lugar do som nos meios audiovisuais. Tanto no campo teórico quanto no âmbito da realização, a maior atenção dedicada à imagem revelou uma postura que relegava o som a um segundo plano.

De acordo com Ángel Rodríguez, a existência de uma primazia da imagem é uma questão histórica e metodológica. Segundo ele, os seres humanos desenvolveram técnicas de desenhos que permitiram a fixação das sensações visuais desde a pré-história, enquanto a possibilidade de fixar os sons surgiu muito mais tarde, a partir da invenção da escrita. A escrita, no entanto, restringe-se aos sons vinculados à fala e os sistemas confiáveis para fixar e reproduzir os sons surgiram somente no século XX. Dessa forma, os estudos sobre as sensações sonoras são um fato mais recente, ao contrário dos conhecimentos em torno das sensações visuais, que evoluíram com grande intensidade ao longo dos séculos, principalmente, por meio da pintura. (RODRÍGUEZ, 2006)

Nesse sentido, se a atitude perceptiva do espectador diante de uma obra audiovisual é, antes de tudo, uma ação conjunta da visão e da audição, não é pertinente desconsiderar o som como parte fundamental da experiência. Para Rick Altman, a noção de que é possível assistir uma obra sem som, mas não sem imagens, é uma verdadeira falácia (ALTMAN apud SÁ; COSTA, 2011). Esse pensamento está em consonância com o conceito da "audiovisão" proposto por Michel Chion, onde o ver influencia o ouvir e vice-versa. (CHION, 2011)

Dentro dessa perspectiva, o crescimento do campo dos estudos do som (sound studies) tem contribuído significativamente para a mudança de pensamento a respeito do universo sonoro do audiovisual. Atualmente, no Brasil, grande parte dessa discussão está inserida nos estudos sobre o cinema. Nos últimos encontros da Associação Brasileira de Cinematográfica ${ }^{1}$, por exemplo, o som foi levado à discussão em mesas específicas sobre o assunto: $O$ som no

\footnotetext{
${ }^{1}$ As informações completas sobre as mesas realizadas nas edições da Semana ABC estão disponíveis no site da Associação Brasileira de Cinematografia. Disponível em: http://abcine.org.br/site/semana-abc/ Acesso em: 18 Mai. 2017.
} 
cinema contemporâneo: conceitos e novas tecnologias (2012); O pensamento sonoro no cinema brasileiro contemporâneo (2013); A sonoridade dos filmes brasileiros atuais (2014); Introdução ao som no audiovisual (2015); Som (2016); Produtor de som: novos conceitos para a realização sonora no audiovisual (2017).

Recentemente, os encontros anuais da Sociedade Brasileira de Estudos de Cinema e Audiovisual (SOCINE) também passaram a reunir discussões específicas sobre o som no cinema. O marco inaugural foi o $13^{\circ}$ Encontro realizado na Escola de Comunicações e Artes da Universidade de São Paulo (ECA/USP). O evento ocorreu em 2009 e diversos trabalhos sobre o assunto foram apresentados ${ }^{2}$, dentre eles: Som e ritmo interno no plano-sequência, apresentado por Fernando Morais da Costa; Se podes ouvir, escuta: som-imagem em Ensaio Sobre a Cegueira e considerações sobre sua gênese, apresentado por Kira Santos Pereira; $O$ rádio e os silêncios: apontamentos sobre o uso do som em "Cinema, Aspirinas e Urubus", apresentado por Rodrigo Octávio D Azevedo Carreiro; A estética sonora em Lucrecia Martel: os elementos sonoros como constituintes da narrativa, apresentado por Natalia Christofoletti Barrenha; A relação música/cinema e o campo teórico, apresentado por Suzana Reck Miranda; Alan Splet: revisão crítica da obra, apresentado por Eduardo Simões dos Santos Mendes.

Outro evento importante foi o II Seminário Internacional Cultura da Música: som + imagem, realizado no Rio de Janeiro, em 2011. Os artigos apresentados no seminário foram posteriormente publicados no livro Som + Imagem, organizado por Simone Pereira de Sá e Fernando Morais da Costa. Nesse mesmo período foram lançados outros livros brasileiros, dentre eles: Som-imagem no cinema, Luiz Adelmo Manzano (2003); O som no cinema brasileiro, Fernando Morais da Costa (2008); O cinema: uma arte sonora, Virginia Flôres (2013); Introdução ao desenho de som: uma sistematização aplicada na análise do longametragem Ensaio Sobre a Cegueira, Débora Opolski (2013); A experiência do cinema de Lucrecia Martel: resíduos do tempo e sons à beira da piscina, Natalia Christofoletti Barrenha (2014); Som direto no cinema brasileiro: fragmentos de uma história, Márcio Câmara (2016).

Cabe, ainda, mencionar a recente pesquisa de Bernardo Marquez Alves - Os Estudos do Som no Cinema: evolução quantitativa, tendências temáticas e o perfil da pesquisa brasileira contemporânea sobre o som cinematográfico - que procurou mapear as pesquisas

\footnotetext{
${ }^{2}$ Os artigos estão disponíveis no site da SOCINE. Disponível em: <http://www.socine.org/publicacoes/anais/>. Acesso em: 9 jul. 2017.
} 
realizadas no Brasil sobre o som no cinema, a partir do começo do século XXI. De acordo com Alves:

\begin{abstract}
O som cinematográfico não pode ser considerado um tema periférico na bibliografia em língua portuguesa sobre o universo dos estudos de cinema e audiovisual. No Brasil, o hábito e o interesse dos pesquisadores e profissionais do som em estudar teoricamente o seu campo de atuação vêm aumentando e, consequentemente, o surgimento de novos documentos e materiais redigidos - presentes principalmente na área acadêmica -, cresce em fluxo até então inédito. A pesquisa brasileira sobre o assunto, que chegou no final do século passado com pouca representatividade, tem nos primeiros onze anos do século XXI, e nos noventa e dois materiais analisados, a demonstração de que este campo de estudo já é digno de ser reconhecido também no país. (ALVES, 2013, p. 114)
\end{abstract}

Observamos que, nos últimos anos, houve um crescente envolvimento dos profissionais e pesquisadores brasileiros em torno do som no cinema. A centralidade que o assunto tem assumido nas diversas discussões sobre o audiovisual tem contribuído para a consolidação e reconhecimento desse campo de pesquisa no Brasil. Nesse contexto, não é pertinente afirmar que o som no cinema seja pouco discutido ou que exista uma pequena quantidade de material publicado sobre o assunto no país.

Entretanto, no âmbito da televisão a situação é diferente. Por meio de uma pesquisa realizada em importantes encontros nacionais de comunicação e audiovisual ${ }^{3}$, constatamos um pequeno volume de estudos que abordam o som na televisão brasileira. O resultado não foi diferente ao se realizar uma busca nos bancos de teses e dissertações de universidades que oferecem a formação em televisão, ou formações correlatas: Universidade de São Paulo (USP), Universidade Estadual Paulista (UNESP), Universidade Estadual de Campinas (UNICAMP), Universidade Federal de São Carlos (UFSCAR), Universidade Federal de Pernambuco (UFPE), Universidade Federal do Rio Grande do Sul (UFRGS), Universidade Federal do Rio de Janeiro (UFRJ), Universidade Federal de Minas Gerais (UFMG), Fundação Armando Álvares Penteado (FAAP), Pontifícia Universidade Católica (PUC) e Universidade Anhembi Morumbi. Esse levantamento foi realizado em 2015 e as palavras-chaves utilizadas foram: som, sonoro, sonoridade, sonoplastia, sound design, trilha sonora, televisão, TV, teledramaturgia, ficção seriada, seriado, minissérie e telenovela.

Os estudos encontrados são, em sua maioria, análises sobre a música na teledramaturgia brasileira, conforme tabela apresentada no Apêndice A. Parte das discussões

\footnotetext{
${ }^{3}$ Sociedade Brasileira de Estudos Interdiciplinares da Comunicação (Intercom); Associação Nacional dos Programas de Pós-graduação em Comunicação (Compós); Sociedade Brasileira de Estudos de Cinema e Audiovisual (Socine).
} 
se concentra no processo de criação das trilhas musicais e seus desdobramentos dentro das narrativas. A outra parcela se propõe a investigar as relações entre o mercado fonográfico e a televisão, dentro da lógica da indústria cultural. Ambas as abordagens são de extrema relevância, mas a quantidade de estudos é pouco expressiva. Ao contrário do que ocorre com o cinema, as discussões sobre os múltiplos aspectos do som na televisão não apresenta um crescimento significativo nas últimas décadas.

Essa questão aponta para um distanciamento entre o pensar e o fazer televisão. No caso específico do Brasil, essa situação reflete o próprio processo empírico de formação da televisão. Na década de 1950, quando a TV foi implantada no país, não havia mão de obra especializada para lidar com a nova tecnologia. Dessa forma, foram as experimentações dos profissionais do rádio e do teatro que forjaram os parâmetros para as primeiras produções televisivas nacionais. Ao longo das décadas, o conhecimento de produção foi se aprimorando e sendo transmitido dos antigos para os novos profissionais.

\begin{abstract}
Os profissionais da geração seguinte aprenderam com os colegas mais velhos, criando uma cadeia que passava o conhecimento do mestre para o aprendiz, como nas sociedades de tradição oral, pré-escritas. Os saberes eram transmitidos de modo antiquado, incompatível com a alta tecnologia do meio eletrônico. Porém, com o tempo, os profissionais ficaram mais especializados, adquiriram mais informação técnica (desenvolvida com a própria evolução tecnológica) e maior repertório e se tornaram mais preparados para a responsabilidade de entreter milhões de pessoas e de falar para elas. No entanto, houve pouca sistematização dos conhecimentos e procedimentos referentes ao fazer televisivo. (SADEK, 2008, p. 11-12)
\end{abstract}

De modo geral, o conhecimento em torno da produção televisiva se desenvolveu sem que houvesse um grande envolvimento dos pesquisadores no processo. De acordo com Arlindo Machado, o desinteresse dos estudiosos pela televisão pode ser explicado pela existência de uma postura que relega a TV a uma segunda categoria. Esse pensamento tenta se apoiar no caráter industrial e mercadológico da produção, o qual, segundo Machado, é um equívoco, uma vez que essa ideia tende a considerar que as coisas fora da televisão são diferentes, quando na verdade não são. A transformação da cultura em mercadoria pode ser percebida em todas as partes, então "por que deveria a televisão pagar sozinha pela culpa de uma mercantilização generalizada da cultura?”. (MACHADO, 2009, p. 10)

Dessa forma, a televisão pode ser abordada como um espaço criativo, com linguagem e técnicas específicas, as quais possibilitam que os realizadores deem forma às suas aspirações. Nas palavras de Machado, a TV é considerada "um dispositivo audiovisual através do qual uma civilização pode exprimir a seus contemporâneos os seus próprios anseios e 
dúvidas, as suas crenças e descrenças, as suas inquietações, as descobertas e os vôos de sua imaginação". (Ibidem, p. 11)

Seguindo essa linha de pensamento, a presente pesquisa propõe uma abordagem da televisão brasileira por meio de um diálogo com os estudos do som, tendo como eixo central a investigação das formas de utilização dos elementos sonoros na construção das narrativas das telenovelas.

Em busca desse objetivo, apresentaremos inicialmente um panorama histórico da televisão brasileira, com enfoque na evolução do aparato técnico sonoro televisivo. Procuramos mapear as principais transformações que ocorreram nos processos da realização do som nas telenovelas de 1950 até o começo do século XXI. Para construir esse percurso recorremos, sobretudo, aos depoimentos de profissionais que atuam, ou atuaram nas áreas voltadas à produção sonora em televisão: sonoplastia, produção de áudio, supervisão de áudio, entre outras. As informações foram levantadas por meio de visitas técnicas e entrevistas. Os depoimentos coletados foram transcritos e estão disponíveis no Apêndice B.

Posteriormente, apresentaremos um estudo sobre as trilhas sonoras de cinco telenovelas da TV Globo. É importante ressaltar que consideramos a trilha sonora como o conjunto de todos os sons que compõem a telenovela. Dessa forma, nas análises, esses sons foram observados a partir de três categorias principais: vozes, ruídos e músicas.

No caso das músicas e ruídos, eles foram divididos, ainda, em outras categorias. Consideramos as músicas a partir da observação das canções e das músicas instrumentais. A trilha de canções é aquela que possui uma intima relação com o mercado fonográfico, conhecida comercialmente como a "trilha sonora" - nacional e internacional - da telenovela. Essa coletânea é formada por vários artistas que compõe exclusivamente para a trama, ou têm suas canções preexistentes selecionadas para integrar a telenovela. As músicas instrumentais, por sua vez, são variações dos temas das canções, ou temas próprios compostos livremente para momentos específicos da narrativa ${ }^{4}$.

Em relação aos ruídos, eles foram subdivididos em: ruídos de sala, ruídos ambientes e efeitos sonoros. Os ruídos de sala, também chamados de foley, são todos os sons relacionados à ação das personagens em cena: passos, movimentação de roupa e interação com objetos. Os ruídos ambientes, por sua vez, são os sons que remetem ao espaço da cena, aqueles que fazem

\footnotetext{
${ }^{4}$ As músicas instrumentais compostas especificamente para as telenovela também são conhecidas como músicas incidentais. Para maior compreensão sobre o processo de criação da trilha musical da telenovela verificar: RIGHINI, Rafael Roso. A trilha sonora da telenovela brasileira: da criação à finalização. São Paulo: Paulinas, 2004.
} 
parte de um lugar específico e constroem acusticamente o cenário. Por fim, denominamos de efeitos sonoros os sons que não são diretamente produzidos pelo homem, mas são utilizados para pontuar e acrescentar um valor narrativo à ação. Em alguns casos, os efeitos sonoros podem representar sons que não são produzidos por fontes sonoras que pertencem à nossa realidade. Esses, normalmente, são obtidos por meio de sínteses eletrônicas que manipulam as propriedades de um ou mais sons.

No que diz respeito à seleção das cinco telenovelas, a metodologia adotada considerou, em primeiro lugar, o viés histórico proposto pela pesquisa. Inicialmente, o intuito era começar a linha do tempo ainda na primeira década da televisão. No entanto, as produções dos anos 1950 foram majoritariamente realizadas ao vivo, não existindo registros audiovisuais das telenovelas dessa época. Conforme veremos com mais detalhes adiante, as gravações dos programas de televisão começaram a acontecer a partir da década de 1960, com a chegada do videotape ao Brasil. No caso das telenovelas, as gravações desse período não foram sistematicamente preservadas e os poucos registros existentes são insuficientes para compor o estudo proposto por essa pesquisa.

Diante desses fatos, adotamos a década de 1970 como o ponto de partida e a TV Globo como foco do estudo. Levamos em consideração três questões principais: a hegemonia da emissora em relação às telenovelas brasileiras a partir dos anos 1970; o fato da emissora ter mantido a produção das telenovelas ininterrupta desde 1965 até os dias atuais; e a existência de registros das telenovelas produzidas dentro do período analisado.

A partir da definição pela TV Globo, houve a necessidade de criar um recorte diante da grande quantidade de telenovelas produzidas pela emissora. Nesse contexto, delimitamos a análise de uma única telenovela por década, de 1970 até a segunda década do século XXI. Adotamos como critério de escolha as telenovelas exibidas no horário nobre ${ }^{5}$ da emissora, optando pelas seguintes obras: Pecado Capital (1975), Roque Santeiro (1985), Renascer (1993), Senhora do Destino (2004) e Avenida Brasil (2012).

Utilizamos como referência as telenovelas com os maiores índices de audiência de cada década. Porém, como os dados oficiais das medições do Ibope não são públicos, baseamo-nos em valores publicados em sites, revistas e jornais eletrônicos. Em relação à década de 1970, havíamos inicialmente adotado Irmãos Coragem (1970), telenovela de Janete Clair que foi um dos marcos da modernização do gênero na TV Globo. O sucesso da

\footnotetext{
${ }^{5}$ Estamos fazendo referência às telenovelas exibidas após o Jonal Nacional, popularmente conhecidas como "novelas das oito", por serem inicialmente exibidas às 20 horas. Entretanto, é válido ressaltar que ao longo das décadas esse horário sofreu alterações e atualmente está fixado às 21 horas.
} 
telenovela rendeu à TV Globo índices de audiência maiores do que a própria final da Copa do Mundo disputada entre Brasil e Itália (MEMÓRIA GLOBO, 2013). No entanto, devido aos incêndios ocorridos na TV Globo, em 1971 e 1976, a emissora perdeu parte do acervo, e o escasso material preservado de Irmãos Coragem inviabilizou a análise da mesma. Sendo assim, optamos por Pecado Capital (1975), mantendo a escolha por uma obra de Janete Clair e considerando o fato de que essa telenovela foi a primeira transmitida em cores no horário nobre da TV Globo. Em relação às outras telenovelas, consideramos os seguintes valores de médias gerais de audiência: Roque Santeiro 67 pontos; Renascer 60 pontos; Senhora do Destino 50 pontos; Avenida Brasil 45 pontos.

É importante destacar que as telenovelas possuem em média 180 capítulos, que totalizam uma obra com mais de 100 horas de duração. Dessa forma, as análises se desenvolveram por meio de uma amostragem, composta pelo capítulo 1 e um capítulo intermediário de cada telenovela (capítulo 100). Essa definição baseou-se na existência de dois contextos diferentes da produção das telenovelas: no caso do capítulo 1, a produção é realizada com antecedência e normalmente existe um maior tempo para a criação, realização e finalização, ao contrário dos capítulos intermediários, que são produzidos quando a telenovela já está sendo exibida e o processo acontece em ritmo acelerado para dar conta das exibições diárias. O tempo é um fator preponderante para a elaboração dos capítulos, então os capítulos intermediários podem apresentar um acabamento diferente em relação ao capítulo 1, pois são mais suscetíveis à falta de tempo. Dessa forma, o estudo do capítulo 1 e do capítulo 100 de cada telenovela permitiu a observação da influência dos diferentes contextos de produção no resultado sonoro de cada capítulo. 


\title{
2. A evolução tecnológica e os processos da produção sonora
}

O marco inaugural da televisão brasileira foi a primeira transmissão da TV Tupi de São Paulo, em 18 de setembro de 1950. Entre os responsáveis pelo acontecimento, destaca-se a figura do jornalista Assis Chateaubriand, um empreendedor que não mediu esforços para trazer o novo meio de comunicação para o Brasil.

Em países onde o cinema já estava consolidado, como os EUA e a França, o surgimento da televisão provocou uma transformação no cenário audiovisual:

\begin{abstract}
Nos Estados Unidos, o cinema inicialmente entrou em conflito com a TV, mas aos poucos a legislação e as forças econômicas em jogo redesenharam a cadeia audiovisual de forma que TV e cinema passaram a fazer parte de um mesmo complexo, sem que perdessem certo grau de autonomia; na França, por sua vez, onde a TV foi majoritariamente pública até os anos 1980, a forte intermediação do Estado levou os canais a se tornarem os principais meios financiadores do cinema, fato que se intensificou, principalmente, com o surgimento da TV paga (mais especificamente o Canal Plus). (BUTCHER, 2006, p. 19)
\end{abstract}

No Brasil a situação foi diferente. As produções cinematográficas nacionais dos anos 1940 e 1950 estavam praticamente centralizadas no Rio de Janeiro através da Cinédia, Brasil Vita Film e Atlântida. Em São Paulo, apesar de alguns projetos ambiciosos, o número de produções nessa fase foi inexpressivo, resumindo-se a praticamente três filmes no período de 1933 a 1949: A Eterna Esperança de Léo Marten (Companhia Americana de Filmes); uma fita de Gilberto Rossi estrelada pelo palhaço Arrelia; e Quase no Céu de Oduvaldo Viana (Estúdios Tupan, 1948), que se valia do elenco das Rádios Associadas Tupi e Difusora. (GONZAGA; GOMES, 1966, apud SILVA, 1981)

Apesar do filme de Oduvaldo Vianna estabelecer um intercâmbio entre rádio e cinema, esse foi um ato isolado e não havia, nessa época, uma intensa troca entre os meios. Da mesma maneira, não houve no Brasil uma relação direta entre cinema e televisão nos seus primeiros anos de convivência, de tal forma que cada meio traçou seu percurso independentemente. Assim, a televisão brasileira buscou no rádio e no teatro sua principal fonte de referência.

Ao contrário da TV americana, que já encontrara no cinema uma infraestrutura de imagem e som para o fornecimento de recursos humanos, bem como a experiência com produções de Hollywood diretamente para a televisão, a nossa televisão iria abastecer-se no rádio. Como a Vera Cruz encerrava suas produções em 1954 e nas telas predominavam as chanchadas, desprezadas como produtos de ínfima qualidade, 
a televisão encontraria no teatro a sua fonte fornecedora de pessoal e dramaturgia. (BRANDÃO, 2010, p. 40)

No início dos anos 1940, o rádio brasileiro vivia o seu apogeu. As radionovelas eram uma das grandes atrações da época, sendo transmitidas em vários horários do dia. A Rádio São Paulo, especialista no gênero, chegou a transmitir cerca de 20 radionovelas diárias na década de 1950. O teatro, apesar da sua presença majoritária no Rio de Janeiro, já havia concretizado um relacionamento fértil com o rádio nas produções dos radioteatros, considerados pela crítica da época como "a essência da arte radiofônica". (SILVA,1981, p. 11)

A televisão brasileira, por sua vez, aproveitou toda essa experiência para começar a trilhar seu caminho, e as primeiras teledramaturgias foram transposições de obras consagradas no rádio. Nos primeiros meses da TV Tupi, por exemplo, o Teatro Walter Foster transmitiu alguns textos que já haviam sido veiculados na Rádio Difusora. Dentro dessa lógica de buscar nos êxitos radiofônicos uma programação para a televisão, surgiram também as primeiras adaptações dos radioteatros.

Durante a década de 1950, os teleteatros acabaram se firmando como o principal gênero da teledramaturgia brasileira, exibindo principalmente clássicos da dramaturgia e da literatura mundial. Essa referência à chamada "alta cultura" era facilmente absorvida pela pequena audiência da época, formada basicamente por uma elite econômica que detinha os poucos aparelhos de televisão existentes no Brasil. As novas emissoras que surgiram em São Paulo nos anos 1950 também investiram no teleteatro para desenvolver uma teledramaturgia, como foi o caso da TV Paulista e da TV Record. No Rio de Janeiro não foi diferente, e a sucursal carioca da TV Tupi e a TV Rio também investiram no gênero.

Nesses primeiros anos da televisão brasileira, as telenovelas também estavam sendo adaptadas do rádio, utilizando-se dos escritores das radionovelas e de grande parte dos radioatores. A primeira telenovela brasileira, Sua vida me pertence, foi escrita por Walter Foster e transmitida pela TV Tupi em 1951. Nessa época, os capítulos eram exibidos de duas a três vezes por semana e possuíam em média 20 minutos. Além das dificuldades econômicas e estruturais das emissoras, que acabavam concentrando todas as suas forças na realização dos teleteatros, havia também certo preconceito por parte do público que considerava a telenovela como um gênero de valor menor. Dessa forma, as telenovelas estavam presentes em menor número na programação das emissoras nos anos 1950. 


\title{
2.1. Década de 1950: a televisão ao vivo
}

No Brasil, os equipamentos de videotape começaram a ser efetivamente utilizados a partir dos anos 1960, antes disso, a produção televisiva brasileira foi predominantemente realizada ao vivo ${ }^{6}$. Na teledramaturgia, os programas aconteciam dentro dos estúdios, uma vez que os equipamentos eram de grande porte e restringiam a realização de cenas em ambientes externos. De acordo com José Castellar:

\begin{abstract}
Não havia equipamento de televisão para externas, que só surgiu mais tarde, começando a ser usado em futebol. Para sequências externas de duas uma: [...] ou nós as montávamos no estúdio [...], ou fazíamos um filme. E quando se filmava, não havia a possibilidade de usar filme sonoro, pois nós não tínhamos equipamento para isso. De forma que eram somente cenas mudas ou narradas. (CASTELLAR, 1977 apud SILVA, 1981, p. 72)
\end{abstract}

Nesse contexto, as produções precisavam se ajustar ao tamanho dos estúdios e à estrutura das emissoras. Em uma história com muitos cenários, por exemplo, a troca dos mesmos acontecia durante a própria exibição do programa. Em alguns casos, eram utilizados dois estúdios simultâneos, ambos equipados com câmeras, luzes e microfones. Em cada estúdio era montado um cenário diferente e as transmissões eram alternadas diretamente de um para o outro. A TV Paulista, para citar um caso, ficava em um prédio na esquina da Rua da Consolação com a Avenida Paulista. A emissora possuía dois estúdios: o maior montado no andar térreo do prédio, destinado à maior parte da produção da emissora; e o menor localizado no segundo andar, que era utilizado para as transmissões dos comerciais. Quando a história precisava de muitos cenários, a produção recorria aos dois estúdios.

[...] os vários sets necessários eram montados parte no andar debaixo e parte no de cima. E o que acontecia? Muitas vezes, ao terminar uma cena no set construído no andar térreo - estúdio artístico -, o ator saía correndo escada acima para alcançar a tempo o outro estúdio e interpretar a próxima cena, ali desenrolada. Terminada esta, muitas vezes ele tinha de voltar correndo escada abaixo, para atuar no cenário anterior. [...] No caso do Teledrama (teleteatro), para dar-se tempo ao ator de correr de um estúdio para o outro, a câmera deslocava-se por um longo tempo num vaso,

\footnotetext{
${ }^{6}$ Nos anos 1950 as emissoras de televisão podiam recorrer às câmeras cinematográficas para registrar os programas. Posteriormente, o filme era exibido pelo telecine, um equipamento que usava uma câmera de TV para captar as imagens de um projetor. Os telejornais, por exemplo, registravam acontecimentos pela cidade usando filmes de $16 \mathrm{~mm}$, mas as câmeras $16 \mathrm{~mm}$ usadas pelas emissoras de televisão nessa época não registravam sons. Assim, as imagens filmadas eram narradas pelos apresentadores no momento da transmissão do telejornal. O telecine também era usado para exibir filmes e seriados em película, e a maior parte desse conteúdo era de origem estadunidense.
} 
bibelô, floreado da cortina, ou ainda no rosto da atriz com a qual o ator acabara de contracenar. (SILVA, 1981, p. 71)

O som produzido dentro dos estúdios - como a voz dos atores - era captado através de microfones suspensos por estruturas móveis, boom ou girafa. O boom consiste em uma vara de comprimento variável, contendo um suporte onde o microfone é fixado. O operador de boom sustenta a vara com os braços e posiciona manualmente o microfone no ponto da captação. A girafa é uma estrutura mecânica em que o operador movimenta o microfone com o auxílio de alavancas e manivelas. Existem diversos tipos de girafas, mas basicamente ela é composta por uma haste telescópica na qual, de um lado, fica o suporte com o microfone e, do outro, um contrapeso. A haste é sustentada por uma coluna vertical, que atua como eixo de apoio para o movimento. A coluna é fixada a uma plataforma com rodas (Figura 1). Em alguns casos, há também um banco para o operador visualizar a ação acima do nível das câmeras. (ALKIN, 1980)

Figura 1 - Girafa

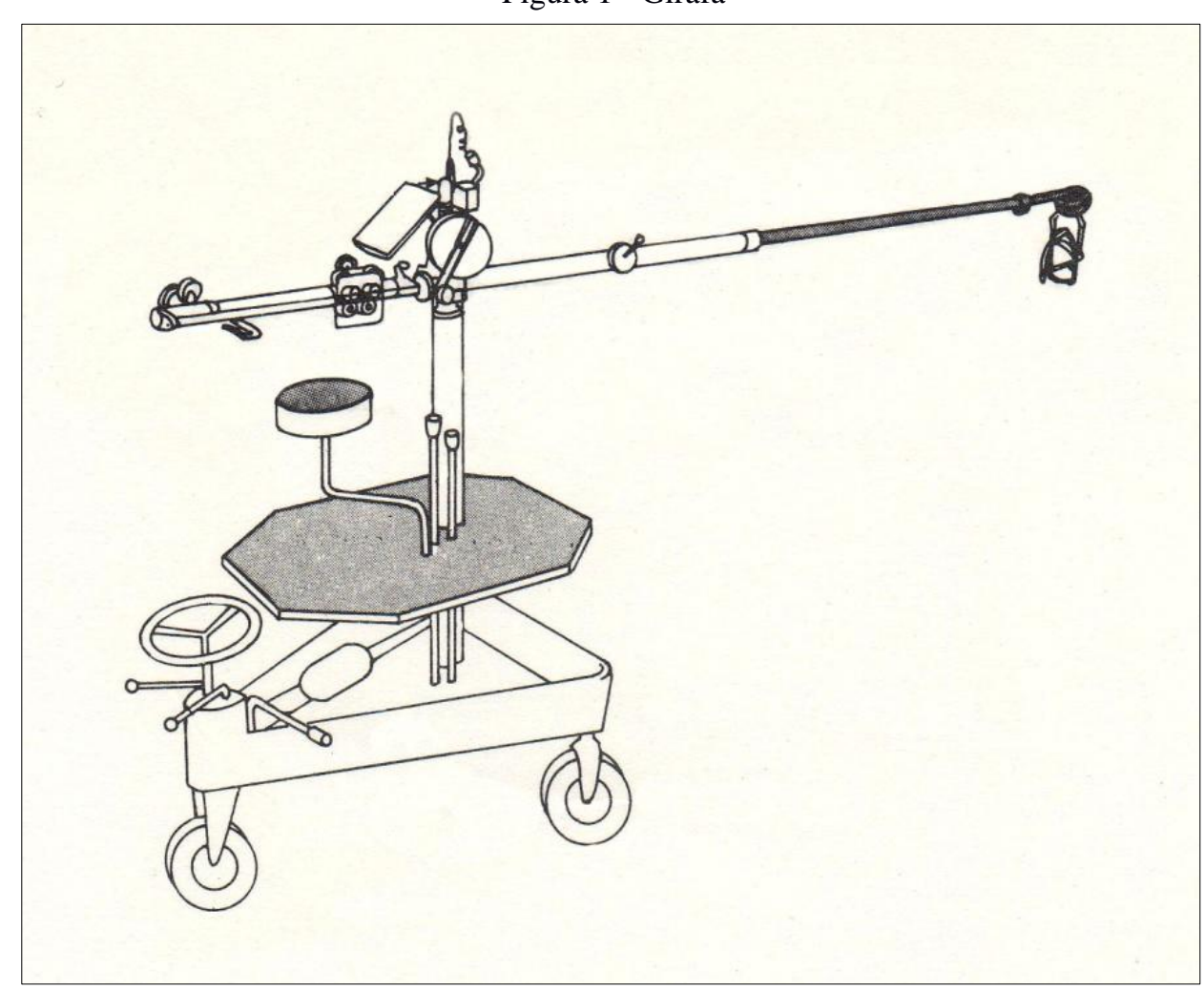

Fonte: ALKIN, 1981, p. 43, modificado pelo autor 
Com a utilização dessas estruturas móveis, o microfone pode percorrer o espaço da cena em busca da melhor posição para a captação do som direto ${ }^{7}$ (Figura 2).

Figura 2 - Realização de cena em estúdio na TV Tupi

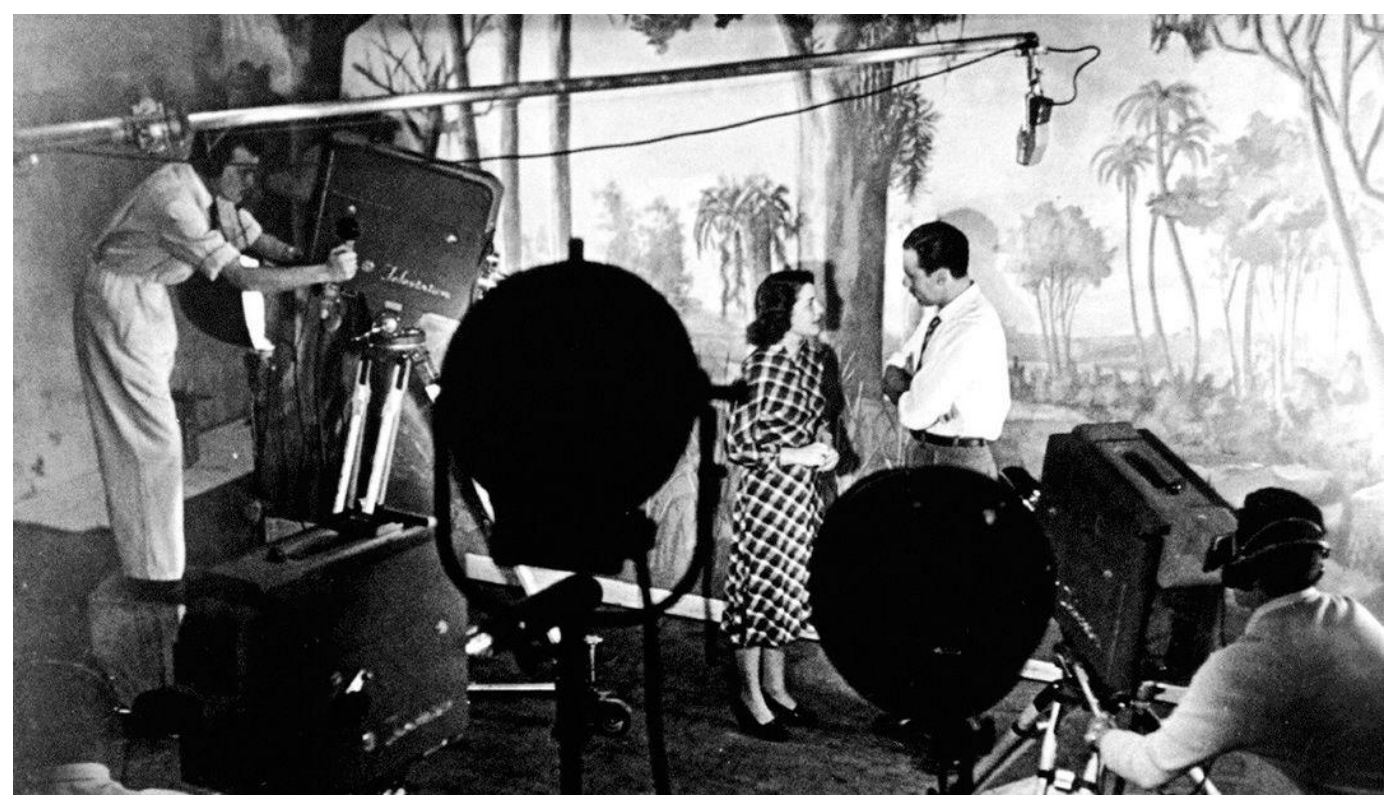

Fonte: Site Band

[...] havia uma exigência com relação aos câmeras muito maior naquela época, antes do video tape, [...] porque não havia gravação. Tudo era feito na hora. [...] Naquele tempo o operador de microfone tinha que atender a vários [...] personagens em cena. $\mathrm{O}$ microfone era pendurado naquela época e se chamava Girafinhas. Havia o Boom, que era um material mais complicado e havia a Girafinha, material mais leve e de transporte mais fácil de um lugar para outro. Usava-se então a tal Girafinha, microfone suspenso. E a grande luta na época era captar a voz dos artistas sem o microfone aparecer. De modo que a derrota do diretor de TV e dos câmeras era quando enquadravam o microfone. Muitas vezes, com o artista falando baixo, era preciso aproximar muito e... então era uma luta para não mostrar o microfone. Eram operadores que tinham que aliar bom gosto e senso artístico com agilidade. (CASTELLAR, 1977 apud SILVA, 1981, p. 73)

Além do som direto, outros elementos sonoros eram acrescentados às narrativas. Esse trabalho era realizado pelo sonoplasta, que, nessa época, tinha como principal função cuidar da trilha musical dos programas. Seguindo as indicações do roteiro e as instruções do diretor, o sonoplasta procurava nos discos as músicas que comporiam as cenas. Salathiel Coelho, um dos principais sonoplastas dessa época, ressalta que as músicas eram fundamentais tanto para as narrativas quanto para a própria dinâmica dentro dos estúdios:

\footnotetext{
${ }^{7}$ Expressão que designa todos os tipos de sons produzidos e captados durante a realização das cenas.
} 
Cada personagem era marcado com um tema. Quando ele surgia, eu soltava a música. E eu sempre fui muito cuidadoso com isso. Era importante para os atores quando eles entravam em cena ao som da música que marcava o personagem deles. (BRYAN; VILLARI, 2014, p. 27)

O sonoplasta inseria as músicas no momento da encenação e era preciso atenção e habilidade para inserir as músicas no ponto correto da cena (Figura 3).

O grande desafio - até porque a tecnologia limitava muito o processo criativo - era conseguir colocar em sincronismo uma música no melhor ponto. Então, o sonoplasta habilidoso e reconhecido artisticamente era aquele que conseguia com aquelas ferramentas do meio analógico colocar uma música para ela caber na cena, conseguir que o final daquela música com o final da cena, e que no início casasse direito. (MEIRELLES, 2016)

Figura 3 - Sonoplasta TV Tupi

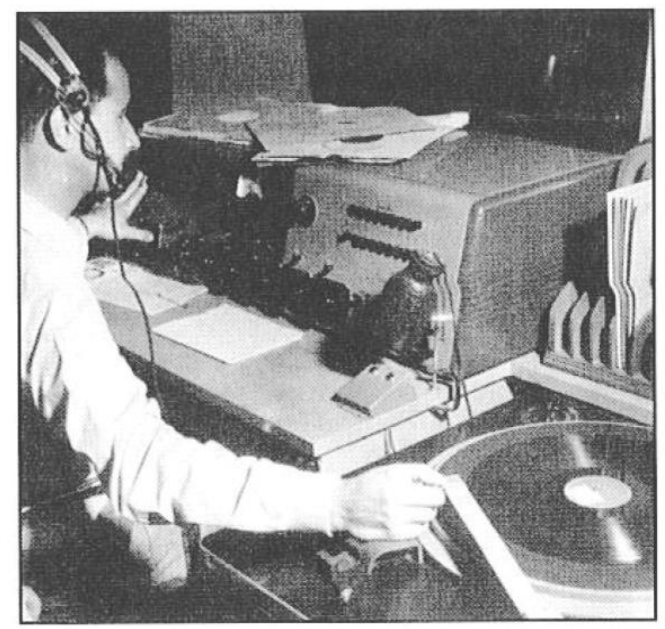

Fonte: SILVA, 2004, p. 21

Além das músicas, o sonoplasta também podia adicionar ruídos pontuais para marcar a ação: tiros de arma de fogo, toques de campainha ou telefone, portas se abrindo ou fechando, entre outros. No entanto, era comum que esses ruídos fossem produzidos dentro do estúdio, em sincronia com as ações dos atores. Essa técnica era muito utilizada no rádio, conhecida como "ruidagem". O contrarregra era o profissional que realizava essa atividade, utilizando diferentes materiais para produzir os mais variados tipos de ruídos. Castellar descreve a importância do contrarregra nas radionovelas:

Quando uma novela era irradiada, só tinha a voz e o "script" sendo criado um clima pelo ator, pelas inflexões, a sonoplastia muito bem cuidada e o contrarregra que era o verdadeiro herói. Este, acompanhando o texto, já devidamente anotado nos ensaios, fazia os ruídos necessários à ambientação. Uma novela sem o contrarregra 
não tinha o mesmo efeito; este emitia os sons como passarinhos utilizando três dedos na boca ou uma rolha de garrafa esfregada em uma superfície lisa, com cocos fazia o galope de cavalo, passos que chegavam ou que se afastavam em uma tábua, ventilador em diferentes velocidades sobre o papel alumínio fazendo brotar o rumor da chuva ou o barulho do vento [...] abria e fechava portas, com as mãos ia amassando um papel celofane para dar ideia de incêndio, com grãos de chumbo movimentados sobre um tamborete ou uma bexiga de borracha na qual introduzia chumbinhos imitava perfeitamente o mar. O contrarregra, o herói anônimo das radionovelas, fazia um trabalho com os sons mais incríveis; tinha papel fundamental, pois sem ele não teria uma verdadeira radionovela. (CASTELLAR, 1978, apud BELLI, 1980, p. 122)

De modo geral, a sonoplastia realizada na televisão nesse período era bem similar à que era feita no rádio. Além da migração dos profissionais de um meio para o outro, a própria estrutura tecnológica de áudio era semelhante.

O áudio na televisão nasceu do rádio, ou seja, o rádio era uma coisa de fato real no Brasil, existia e todo mundo conhecia. A televisão veio para preencher uma coisa de imagem, só que ninguém sabia como seria a imagem. Mas o áudio todo mundo já conhecia, já tinha uma estrutura de áudio que era do rádio. Então, a estrutura de áudio foi adaptada para trabalhar com televisão. Ou seja, até hoje, a gente "sofre" com as funções dos cargos de áudio, são todos cargos que vieram do rádio. Por exemplo, ao invés de engenheiro de mixagem, a gente tem o sonoplasta, que é uma função de rádio. O sonoplasta é aquele profissional que nas radionovelas colocava a trilha sonora, colocavam os efeitos e tal. Fazia a sonoplastia, a "plastia" do som, a modelagem do som. A gente herdou inclusive a nomenclatura, veio tudo do rádio. (RONCONI, 2016)

É válido ressaltar que a dificuldade econômica das emissoras podia ser sentida em sua estrutura técnica. Segundo Geraldo Casé, produtor da TV Rio nesse período, "era impossível fazer uma boa televisão, porque ela funcionava contra qualquer princípio técnico. As câmeras Dumont eram consertadas com arame, barbante e esparadrapo". (COSTA, 1986, apud BRANDÃO, 2005, p. 32) De acordo com João Loredo, na TV Tupi do Rio de Janeiro “os estúdios não tinham tratamento acústico e nem ar-condicionado, por isso deixávamos as janelas abertas por causa do calor. A estação era próxima ao cais do porto e os apitos dos navios eram ouvidos no ar". (LOREDO, 1991, apud BRANDÃO, 2005, p. 32)

Em São Paulo as produções também enfrentavam dificuldades devido às limitações tecnológicas das emissoras. Segundo José Castellar, a TV Paulista e a TV Tupi não tinham o número adequado de microfones:

Tanto uma emissora quanto a outra, não dispunham [...] de dois microfones iguais, de forma que para passar de uma cena para outra, era preciso aumentar o volume da música; enquanto subia a música, o microfone se deslocava de um cenário para o outro. Isso prejudicava evidentemente o rendimento. Mas o público não tinha outra 
coisa para assistir e vibrava inclusive com as soluções que nós procurávamos. (CASTELLAR, 1977 apud SILVA, 1981)

\subsection{Década de 1960: a chegada do videotape ao Brasil}

Na década de 1960, a televisão brasileira começou a tomar novos rumos com a chegada dos equipamentos de videotape. O primeiro sistema que, na prática, viabilizou a gravação eletrônica de sons e imagens em fita magnética foi o Videotape Recorder VRX-1000, lançado pela Ampex em 1956. Em novembro do mesmo ano, a emissora de televisão norteamericana CBS fez o primeiro uso da tecnologia no noticiário The News. O videotape começou a ser testado pelas emissoras brasileiras ainda no final dos anos 1950, mas foi durante a inauguração de Brasília, em 1960, que a TV Record fez o primeiro uso oficial do equipamento em terras brasileiras.

O formato de videotape dessa época era o Quadruplex. Esse nome remete à forma como o equipamento realiza a gravação, ou seja, utilizando quatro cabeças que giram para registrar as informações verticalmente na fita magnética (Figura 4). A banda de vídeo fica na parte central da fita de 2 polegadas, ocupando quase a totalidade da mesma. Nas extremidades, localizam-se outras três bandas de tamanho menores: a pista de áudio do programa; a pista cue que, normalmente era utilizada para gravar informações; e a pista de comando, responsável por sincronizar o movimento da fita com o tambor das cabeças. (ALKIN, 1980) O Quadruplex é um sistema reel to reel e as fitas são acondicionadas em carretéis (Figura 5). O peso médio de cada carretel é de 8 quilos e sua capacidade de armazenamento é de aproximadamente 60 minutos. (BALAN, 2012)

Figura 4 - Diagrama da varredura vertical do Quadruplex

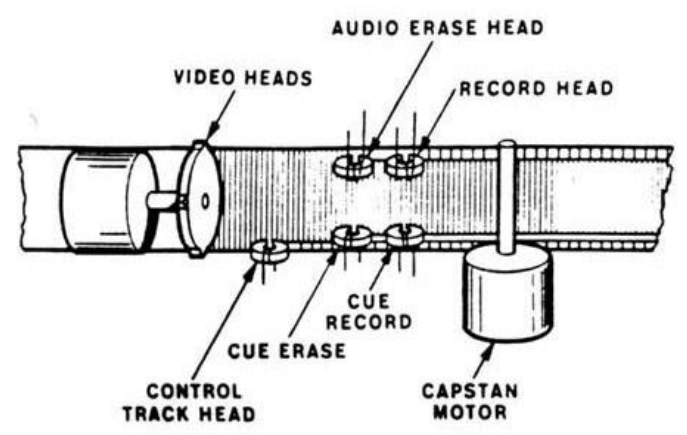

Fonte: Site LabGuy's World
Figura 5 - Carretel com fita magnética de 2 polegadas

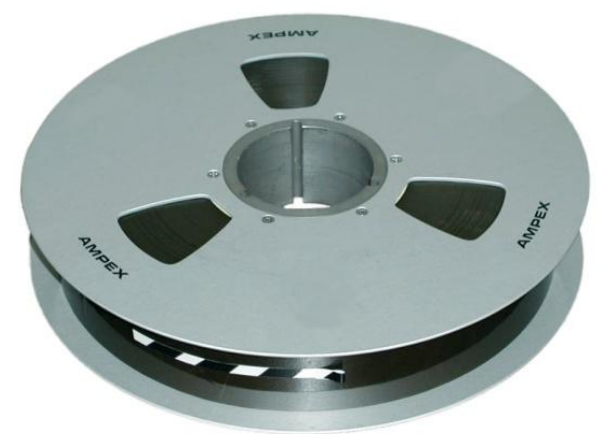

Fonte: Site LabGuy's World, modificado pelo autor 
A introdução do videotape modificou a lógica da televisão brasileira. Com a possibilidade de gravar os programas, as produções ganharam maior agilidade, os erros passaram a ser corrigidos e a linguagem pôde ficar mais elaborada. As gravações permitiram também que os programas fossem ao ar a qualquer momento do dia, o que favoreceu a formação das grades de programação. Aos poucos, as emissoras começaram a aumentar a quantidade dos programas, organizando as exibições tanto horizontalmente (dias da semana), quanto verticalmente (horas do dia).

Entretanto, alguns profissionais da época encararam com pessimismo a chegada da nova tecnologia. A alegação era que a gravação acabaria com o "calor" das transmissões ao vivo, consequentemente os atores diminuiriam seus desempenhos diante da possibilidade de refazer suas falas, gestos e olhares. (SILVA, 1981)

Geraldo Vietri, por exemplo, relata sua experiência ao assistir um dos primeiros testes do videotape na TV Tupi. O fato aconteceu durante a realização da telenovela Esta Noite é Nossa.

\begin{abstract}
Aqui termina a televisão brasileira. Em primeiro lugar o ator não precisa mais ter talento para interpretar, pode ser fabricado... porque errou, apagou, voltou... E mais... Aqui termina o mercado de trabalho da televisão brasileira. O Sul vai acabar, vai acabar o Norte, vai acabar Belo Horizonte, ficarão apenas São Paulo e Rio de Janeiro. (VIETRI, 1977, apud SILVA, 1981, p. 45)
\end{abstract}

Contudo, no caso das telenovelas, o videotape teve um papel fundamental. Foi justamente a tecnologia de gravação que viabilizou a exibição dos capítulos diários. Essa mudança foi imprescindível para que a telenovela viesse a se tornar o principal gênero da teledramaturgia brasileira a partir dos anos $1960^{8}$. A primeira telenovela diária foi 2-5499 Ocupado, exibida pela TV Excelsior, em 1963. Em 1964, a TV Tupi também adotou o formato diário com $O$ Direito de Nascer. Aos poucos, a telenovela começou a ganhar espaço na programação das emissoras ${ }^{9}$.

A inauguração da TV Globo ocorreu em 1965, nesse contexto de transformações. Contando com uma estrutura mais empresarial, a emissora investiu em profissionais e

\footnotetext{
${ }^{8}$ Outro fator importante para a consolidação das telenovelas foi a formação de um novo público de televisão. A partir da década de 1960, o aumento da venda dos aparelhos televisores - que se tornaram mais baratos com a fabricação nacional - permitiu um maior acesso da população à televisão. Esse crescimento foi acompanhado pela sensação de que a TV estaria substituindo o rádio. Os anúncios da época colaboraram com essa ideia, situando a televisão no centro da sala da família brasileira. Dessa forma, os profissionais que migraram do rádio para a TV passaram a legitimar a telenovela apoiados na noção da existência de um público de televisão que remetia aos próprios ouvintes das radionovelas. (BERGAMO, 2010)

9 "De 1963 a 1969, foram produzidas 176 novelas. A TV Excelsior produziu 55, a Tupi, 60, e a TV Globo (criada em 1965) fez 22 novelas”. (BRANDÃO, 2010, p. 54)
} 
tecnologia. Hebert Fiúza, um dos técnicos contratados para colocar a TV Globo em funcionamento, relata que os equipamentos da emissora eram o que havia de melhor naquela época:

Eram quase todos da RCA, à exceção das máquinas de VT, que nós tínhamos exigido que fossem da Ampex. Foi a primeira grande complicação em que nos metemos. Mas, nós já tínhamos uma espécie de receita, sabíamos o que existia de melhor em cada setor. As câmeras tinham de ser RCA, transmissor RCA, antena RCA, mesa de corte, tudo era RCA. Até porque, comprando esse pacote de equipamentos, os custos se tornavam bem menores. Mas, por indicação de um de nossos técnicos, o René (René César Xavier), ficamos sabendo que, em matéria de gravação, não existia nada que superasse a Ampex. (FIÚZA apud SOUZA, C. M., 1984, p. 59)

Figura 6 - Videotape Ampex no início da TV Globo

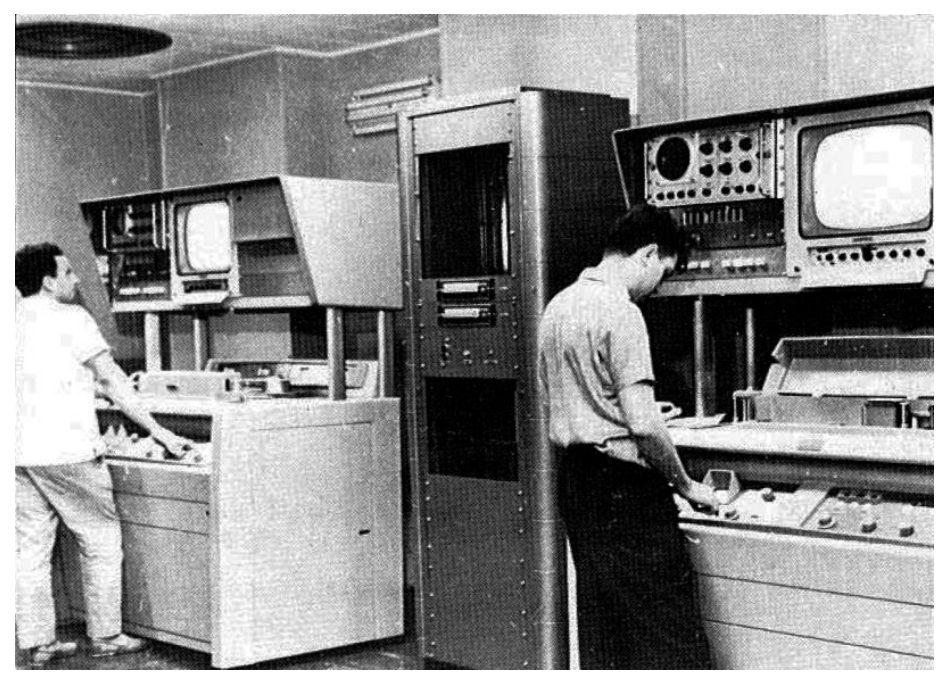

Fonte: SOUZA, C. M., 1984, p.72

A RCA Victor era uma das grandes fabricantes de equipamentos de televisão nesse período. Porém, em relação à tecnologia de gravação, a Ampex foi pioneira ${ }^{10}$. Além do videotape, a empresa lançou o EDITEC em 1963. O equipamento viabilizou as primeiras edições eletrônicas da fita magnética - até então o procedimento era totalmente manual.

A introdução do videotape nas emissoras de televisão foi o primeiro passo para o surgimento da pós-produção. Gravar os programas permitiu que a montagem e finalização dos mesmos acontecessem em uma etapa separada do momento da realização. Com isso, não só

${ }^{10}$ Além do Videotape Recorder VRX-1000, a Ampex lançou em 1964 o VR-2000, equipamento capaz de gravar cores com fidelidade. Dada à relevância das invenções, ambas foram premiadas com Emmy. AMPEX. Disponível em: <http://www.ampex.com/ampex-history/>. Acesso em: 22 nov. 2016. 
os erros podiam ser consertados posteriormente, mas também novos elementos adicionados às narrativas.

Nesse contexto, surgiu a possibilidade de realizar a sonoplastia após a realização das cenas. Assim, a atenção nos estúdios se voltou para o som direto, principalmente no que diz respeito à captação e gravação das vozes dos atores. Os outros elementos sonoros, como as músicas e ruídos, começaram a ser adicionados posteriormente, na etapa da finalização de som.

No caso da TV Globo, a gravação do som direto acontecia no próprio videotape, junto com a imagem. Como o sistema Quadruplex contava com apenas um canal efetivo de áudio na fita magnética para a gravação do som direto, havia uma restrição em relação à quantidade de microfones usados na captação. De acordo com o sonoplasta Guerra Peixe Filho, normalmente se utilizava somente um microfone direcional, que era manipulado pelo operador de boom. No entanto, havia situações em que era necessário recorrer a outras técnicas para se realizar uma boa captação das vozes: "quando tinha um diálogo mais longo, [...] colocava-se um microfone escondido atrás de um abajur, ou algo do tipo e o outro ficava com o boom man." (FILHO, G.P., 2016)

No âmbito da sonoplastia, Guerra Peixe Filho relata que os sons adicionais eram inseridos diretamente no equipamento de videotape. Nessa época, a TV Globo não contava com equipamentos dedicados à finalização de som. Segundo ele, após a montagem das cenas, a fita era encaminhada aos sonoplastas, que acrescentavam as músicas e os ruídos das cenas.

Na década de 1960, quando começou, não tinha gravador (de som separado). A própria fita do VT tinha dois canais. A gente usava o canal um. Então você passava do canal um para a pista de cue, naquele tempo não era canal dois. Cue era onde você marcava para trocar de cena. Então, a gente passava o áudio - que era o principal - do canal um para a pista de cue, acrescentando algumas músicas e ruídos. Depois passava a pista de cue de volta para o canal um - que era o canal que valia acrescentando o resto que ficou faltando quando você passou pela primeira vez. (FILHO, G.P., 2016)

Guerra Peixe Filho enfatiza que as limitações técnicas desse período eram grandes e o processo de sonoplastia demandava tempo e paciência:

Para a gente acertar um tiro levava 2 horas, o tiro estava em uma fita, você ficava apertando o botão e não acertava o tiro de jeito nenhum. Você tinha que fazer isso tudo no dedo. Era fita de áudio com o tiro gravado e para você acertar o tiro na hora certa você ficava até nervoso [...] E quando era tiroteio, era coisa de maluco. (FILHO, G.P., 2016) 
No caso das telenovelas, o tempo era extremamente escasso, uma vez que as produções aconteciam em ritmo acelerado para dar conta dos capítulos diários. No depoimento ${ }^{11}$ do diretor Daniel Filho sobre Irmãos Coragem, podemos ter uma ideia de como era a estrutura de produção das telenovelas da TV Globo desse período:

O ano é de 1970, no dia 8 de junho estreava uma das mais lembradas novelas
brasileiras, Irmãos Coragem [...] Ao rever hoje esta produção, eu lembrei das
condições em que trabalhávamos. Os capítulos tinham perto de 35 minutos e os seis
semanais eram gravados em três dias: dois no estúdio e um na externa. As câmeras
pensavam perto de 60 quilos. Nos pequenos três estúdios, onde os cenários eram
montados e desmontados diariamente, nos outros dias era gravada outra novela. As
cenas eram gravadas diretamente, sem montagem posterior, praticamente sem pós-
produção. As músicas, os ruídos extras, como: tiros, socos... eram feitos na hora.
Apenas nas externas a música era inserida depois. A gravação externa era com duas
enormes câmeras ligadas a um ônibus modificado para receber os equipamentos e
um barulhento gerador que tinha quer ser bem afastado. Em algumas cenas este
roncar, "ronnn!", se faz presente.

\title{
2.3. Década de 1970: os equipamentos portáteis
}

Até o final dos anos 1960, as gravações em ambientes externos ainda eram difíceis de realizar. As produções somente conseguiam sair dos estúdios utilizando unidades móveis, ou câmeras cinematográficas.

\begin{abstract}
Você não tinha uma unidade portátil de gravação, como você tem hoje câmeras portáteis. Você tinha uma unidade móvel, que era um ônibus que se deslocava para os lugares, estacionava, ligava o gerador e tal. Você tinha uma mini central técnica dentro com câmeras tudo cabeado. Como se fosse um estúdio móvel. Então você tinha tudo construído nesse ônibus: áudio, vídeo, as câmeras, todas ligadas nele. As cenas externas eram gravadas assim. Raramente você tinha uma cena gravada em película, que depois era telecinado com a imagem editada junto. Quando você precisava de um sistema extremamente portátil você apelava para isso. (RONCONI, 2016)
\end{abstract}

Com o aprimoramento dos componentes eletrônicos - principalmente com a passagem dos circuitos valvulados para os transistorizados - os equipamentos começaram a ficar cada vez menores. No final da década de 1960, surgiram os primeiros sistemas portáteis para televisão. A empresa Ampex, por exemplo, lançou seu primeiro videotape portátil em 1967, o $V R$-3000. O equipamento era composto por uma espécie de mochila com um pequeno

\footnotetext{
${ }^{11}$ Depoimento retirado do material extra do DVD contendo a versão compacta da telenovela Irmãos Coragem, Globo Marcas, 2011.
} 
gravador Quadruplex, que era conectado por cabos à câmera e ao microfone (Figura 7). O sistema era movido à bateria, o que dava autonomia para a gravação de som e imagem em ambientes externos. O primeiro uso da tecnologia foi nas Olimpíadas de 1968, no México.

Figura 7 - Ampex VR-3000 durante a gravação da telenovela $O$ Cafona, produzida pela TV Globo em 1971.

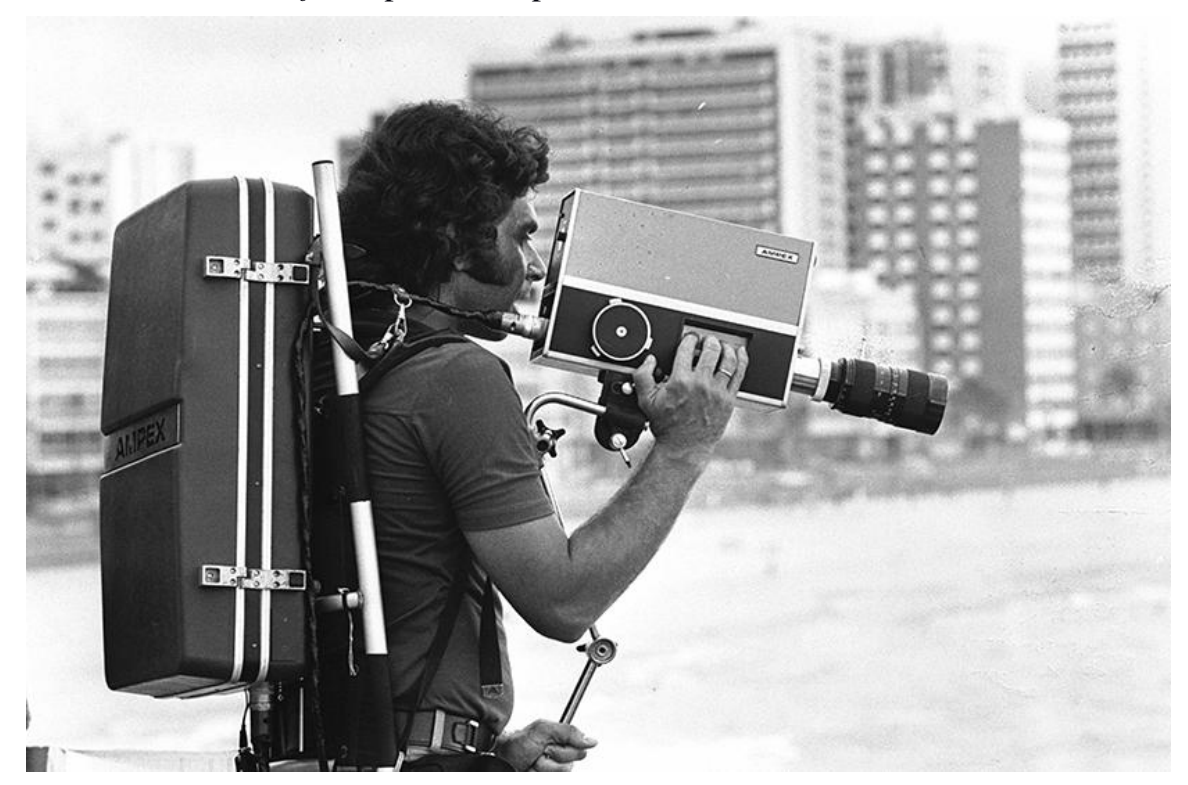

Fonte: Site Memória Roberto Marinho

Em 1969, a empresa japonesa Sony também lançou um equipamento portátil de televisão, o U-matic. A grande inovação foi o uso de fitas magnéticas menores de 3/4 de polegada, que eram acondicionadas em estojos (cassetes). O sistema tinha uma configuração similar ao equipamento portátil Quadruplex, mas o formato da fita reduziu o tamanho dos equipamentos e facilitou a operação. Todavia, o U-matic possuía qualidade de gravação inferior ao sistema Quadruplex. Dessa forma, sua utilização foi mais comum no telejornalismo, substituindo gradativamente as câmeras 16 mm. (BALAN, 2012)

No Brasil, a utilização dos equipamentos portáteis começou a acontecer de forma ampla a partir da década de 1970. Com isso, a captação de som em ambientes externos também se tornou mais viável e frequente. Com a realização de cenas nas chamadas locações - espaços reais que são utilizados como cenários - abriu-se caminho para a incorporação de novas sonoridades à trilha sonora das telenovelas. No âmbito das vozes, por exemplo, as diferentes características acústicas de cada locação proporcionaram ao processo de captação do som direto a possibilidade de registrar as vozes com a reverberação específica de cada espaço. De acordo com Rodrigo Meirelles, supervisor executivo de áudio da TV Globo, na 
emissora a preferência sempre foi pelo emprego de microfones e técnicas de captação que priorizam esse resultado sonoro:

\begin{abstract}
Os microfones aéreos são a prioridade de quem trabalha com áudio, porque a gente sabe da característica do som deles, o quanto a gente consegue, dependendo do posicionamento, a sonoridade mais adequada. A gente tem o controle de acordo com o microfone que a gente escolhe para a cena, o quanto a gente vai captar de "direcionalidade", a gente pode ter um microfone mais direcional ou menos direcional. A gente consegue ter mais daquele ambiente, mais perspectivas sonoras e espacialidades. Então o microfone aéreo é sempre o que a gente prioriza. (MEIRELLES, 2016)
\end{abstract}

Sobre os ruídos, é importante destacar a atuação de Geraldo José na TV Globo, considerado o pioneiro dessa arte no Brasil. Na década de 1940, Geraldo José começou a trabalhar na Rádio Tupi como office boy. Com o auxílio de Orlando Drummond, ele apreendeu o trabalho de contrarregra e começou a desempenhar a função. Em pouco tempo, Geraldo se transformou no principal contrarregra da Rádio Tupi. Nesse período, a convite de Waldemar Noya, o "Didi”, Geraldo José fazia ruídos complementares em alguns filmes da Atlântida Cinematográfica. Em 1962, ele marcou seu início como profissional no cinema com o filme As Sete Evas, de Carlos Manga e Cyll Farney. No ano seguinte, Geraldo José fez Vidas Secas, de Nelson Pereira dos Santos, filme em que os ruídos desempenham papel fundamental. As participações de Geraldo José nos filmes brasileiros ficaram cada vez mais frequentes, ao ponto de ter participado de praticamente todos os filmes do Cinema Novo ${ }^{12}$. Toda essa experiência acumulada por Geraldo José foi levada para a TV Globo, segundo ele:

\footnotetext{
Antes o som ambiente era precário, especialmente nas externas. Passei a reproduzir sons ambientes que eram acrescentados à trilha de áudio depois que o capítulo era editado. Antes, numa cena de luta, por exemplo, os ruídos eram fracos e então o sonoplasta colocava uma música agitada que cobria tudo. Passei a incluir ruídos adicionais que tornavam a cena muito mais realista. (JOSÉ, apud SALVADOR, 2010, p. 97)
}

Ao perguntar o papel de Geraldo José no desenvolvimento do setor de ruídos dentro da TV Globo, o sonoplasta Aroldo Barros definiu sua importância na seguinte frase: "É mais fácil perguntar ao Geraldo José qual o ruído que ele não tem, porque se perguntar qual ele tem, ele tem todos!". Segundo Guerra Peixe Filho, Geraldo José tinha um acervo pessoal de ruídos, que ele mesmo gravava: "ele tinha tudo em fita (de rolo), ele mesmo fazia. Ele tinha um gravador Nagra portátil que ele levava para onde ele queria, ele mesmo gravava os ruídos dele. [...] ele tinha um repertório tremendo de ruídos”. (FILHO, G.P., 2016) O arquivo pessoal

\footnotetext{
${ }^{12}$ GERALDO JOSÉ: O som sem barreiras. 2003. Direção de Severino Dadá.
} 
de Geraldo José chegou a ter entre doze e treze mil tipos de ruídos - na mesma época a BBC de Londres tinha o maior acervo, com vinte mil sons ${ }^{13}$.

Além dessas transformações no âmbito do som, a televisão brasileira passou por uma importante modificação em termos de imagem nos anos 1970. Isso ocorreu oficialmente em fevereiro de 1972, quando a TV Difusora fez a primeira transmissão em cores do Brasil. O evento aconteceu durante a Festa da Uva, em Caxias, no Rio Grande do Sul. Ao longo da década de 1970, as produções em cores começaram a se tornar mais frequentes na programação das emissoras. Em 1973, a TV Globo produziu a primeira telenovela colorida, $O$ Bem-Amado. Dois anos depois, em 1975, Pecado Capital levou as cores também para o horário nobre da emissora.

\subsection{Década de 1980: o novo formato de videotape e os gravadores de som multipista}

Após três décadas em uso, o formato Quadruplex começou a ser substituído por uma nova tecnologia de gravação em fita magnética, o Type C (Tipo C). Projetado pela SMTPE Society of Motion Picture and Television Engineers - os primeiros equipamentos foram desenvolvidos através de uma parceria entre as empresas Sony e Ampex. Lançado em 1976, o Type $C$ utilizava fitas de 1 polegada e operava no sistema helical scan, ou seja, a varredura acontecia no sentido diagonal em relação à fita magnética (Figura 8).

Figura 8 - Diagrama da varredura helicoidal do Type $C$

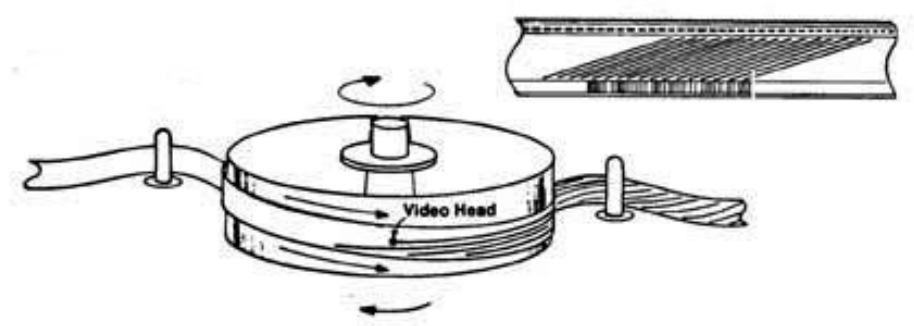

Fonte: Site Experimental Television Center

A qualidade de gravação do Type $C$ era similar ao Quadruplex, mas o sistema helicoidal de varredura reduziu o tamanho dos equipamentos e ampliou as possibilidades para

\footnotetext{
${ }^{13}$ Idem.
} 
as produções em videotape. Em termos de imagem, por exemplo, a tecnologia possibilitava criar efeitos de câmera lenta (slow motion) e congelamento de imagem (still frame). Em relação ao som, as trilhas de áudio na fita magnética ficaram menores, o que permitiu que alguns modelos de Type $C$ tivessem mais canais de áudio, como o Sony BVH-2000 que contava com quatro canais (Figura 9). Inclusive, algumas versões do videotape já utilizavam tecnologia digital de gravação de som em fita magnética, como o Sony BVH-2800 que contava com áudio $P C M^{14}$.

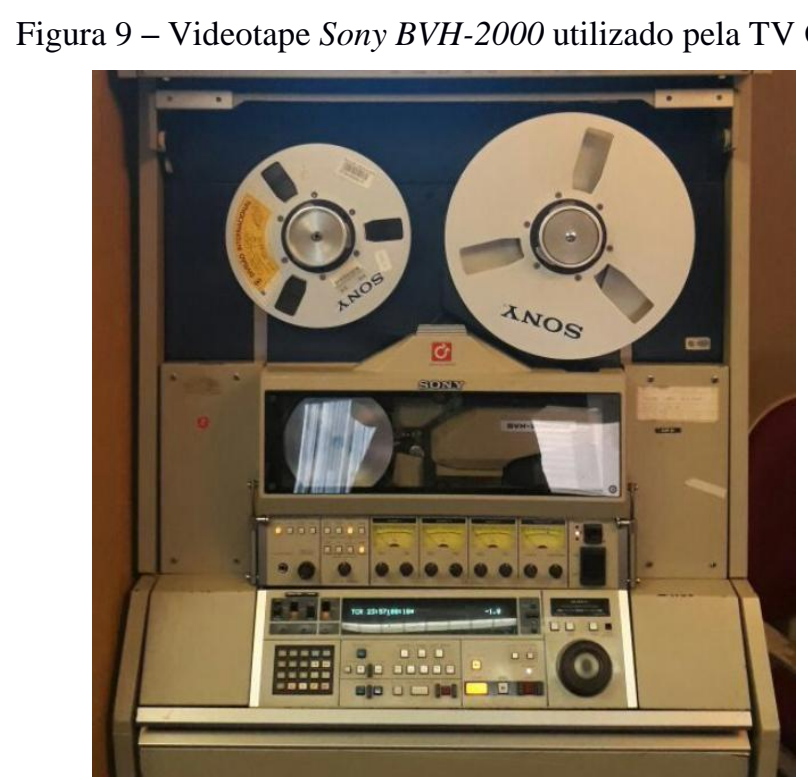

Fonte: Thanus Chalita, acervo pessoal

Na TV Globo, os videotapes Type C começaram a ser implantados na década de 1980. No âmbito da captação de som, a passagem do Quadruplex para o novo formato não gerou grandes impactos. O som direto continuou sendo gravado no videotape junto à imagem. Quando eram utilizados mais de um microfone, os mesmos eram mixados e gravados direto no canal de áudio do videotape.

Quando a gente fala de década de 1970 e 1980 a gente fala em um ou dois canais de som na fita. [...] Se você está falando de estúdio, por exemplo, os seus microfones vinham direto em uma mesa de mixagem e essa mesa de mixagem mandava o áudio

\footnotetext{
${ }^{14} \mathrm{O}$ Pulse-code modulation é um método de digitalizar sinais analógicos por meio de amostragens (sampling). No campo do áudio, os primeiros equipamentos digitais de gravação de som em PCM surgiram a partir de 1970. Em 1971, a empresa Denon fez uma demonstração de uma gravação digital em estéreo com amostragem em 18 bits. A partir de 1975, os gravadores digitais em fita começam a ser utilizados nos estúdios profissionais. AUDIO ENGINEERING SOCIETY, An Audio Timeline. Disponível em: <http://www.aes.org/aeshc/docs/audio.history.timeline.html>. Acesso em: 24 nov. de 2016.
} 
direto para o VT, seja ele Quadruplex, (ou) 1 polegada que veio depois. (RONCONI, 2016)

Em relação à finalização de som, a implantação de gravadores de som multipista ${ }^{15}$ modificou o processo de sonoplastia. O gravador de som (Figura 10) era acoplado ao equipamento de videotape e ambos eram sincronizados através do time code $e^{16}$. Dessa forma, o sonoplasta conseguia manipular o som no gravador em sincronia com a imagem do videotape. O processo acontecia da seguinte forma: após a edição de imagem, a fita do videotape chegava ao setor de sonoplastia contendo o time code e o som direto (diálogos). Primeiramente, o sonoplasta gravava o time code em um dos canais da fita do gravador de som multipista, estabelecendo a sincronia com o equipamento de videotape. Os diálogos também eram gravados em dos canais do gravador de som. Nos canais restantes o sonoplasta adicionava as músicas e os ruídos das cenas. Esses sons eram reproduzidos a partir de discos e fitas magnéticas. Finalizado o processo, tudo era mixado para um único canal e gravado de volta na fita do videotape, junto com a imagem.

Figura 10 - Gravador de som Studer A-80 com oito pistas, similar ao que era utilizado na TV Globo.

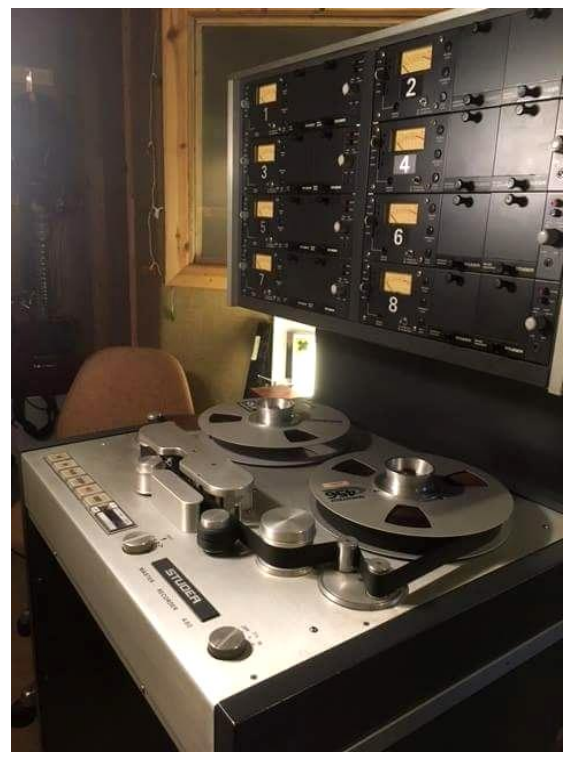

Fonte: Site Gearslutz

\footnotetext{
15 Os equipamentos multipistas são sistemas que contam com múltiplos canais de entradas de som, o que possibilita trabalhar isoladamente cada sinal de áudio. No caso dos gravadores multipistas, os sons são recebidos individualmente pelo equipamento e registrados separadamente no suporte de gravação.

${ }^{16} \mathrm{O}$ time code é um sistema de sincronia que foi desenvolvido originalmente pela EECO, em 1967 . No final da década de 1960, a SMTPE adotou e padronizou o sistema para utilização em produções de áudio e vídeo. Por meio desse padrão, o tempo do vídeo é contabilizado em horas, minutos, segundos e frames. Dessa forma, é possível que dois equipamentos diferentes trabalhem de forma sincronizada a partir de um mesmo time code.
} 
Tínhamos uma máquina de rolo com oito canais que, na verdade, se podia usar seis. Já que no oitavo era gravado o time code para sincronismo da máquina com o VT. Tudo que se gravava no canal sete era inutilizado pelo "zumbido" desse mesmo time code. Portanto, o canal sete não era utilizado. Desses seis canais restantes, dois eram destinados à captura do áudio que vinha do VT. Como era mono, vinha o diálogo principal em um canal e no outro os áudios adicionais, que o editor não pudesse por alguma razão mandar no principal. Sendo assim, sobravam quatro canais pra gente "brincar", como se dizia na época. Colocar ruídos e música, ai entrava em cena a criatividade de cada um. (BARROS, 2016)

De acordo com Aroldo Barros, nessa época, era necessário inventar certos procedimentos para dar forma às construções sonoras mais complexas.

Para sonorizar um tiroteio, por exemplo, era um caos. Imagina uma cena com vinte pessoas numa troca de tiros [...] e a gente ter que sincronizar aquilo. Criávamos mecanismos para fazer esse sincronismo. Exemplo: quando o determinado personagem piscar o olho, soltamos o som do tiro, que vai cair exatamente no tiro. [...] Fazíamos uma base com os principais tiros e quando os canais já estavam esgotados reduzíamos tudo para um determinado canal e liberávamos o que sobrasse pra começar de novo. Depois fazíamos o mesmo processo até ficar pronto. Terminado o ruído tínhamos que colocar as músicas. Havia casos de se passar tudo que estava pronto para o VT e depois voltar pra fita novamente ocupando menos canais, para ter como colocar as músicas. É claro que isso devia perder qualidade, com tantas cópias pra lá e pra cá, mas era o que tínhamos no momento. (BARROS, 2016)

A saída do processo de sonoplastia dos equipamentos de videotape para os gravadores de som multipista representou uma mudança significativa para a pós-produção de som. Principalmente com o aumento do número de canais de áudio - que passaram de dois para seis - viabilizando a criação de trilhas sonoras com uma maior quantidade de elementos.

Por fim, é importante mencionar que, na década de 1980, a TV Globo passou a desenvolver dentro da emissora uma nova atividade relacionada à produção de som. Desde meados dos anos 1970, a TV Globo já estava exportando suas telenovelas para vários outros países, o que gerava a demanda pela criação da chamada banda internacional de som. Também conhecida como $M \& E$ (music and effects), a banda internacional é a trilha sonora composta somente por músicas e ruídos. Os diálogos são dublados posteriormente na língua do país que importa o material. Devido ao aumento das exportações a partir dos anos 1980, a TV Globo criou dentro da emissora um setor dedicado à realização dessa atividade. $\mathrm{O}$ sonoplasta Carlos Pereira foi um dos profissionais que participou desse momento de transição.

Eu comecei a trabalhar na Rede Globo pela "Herbert Richers", pois na época a Rede Globo não tinha divisão internacional nem esse tipo de departamento. A Herbert fazia esse trabalho que, em seguida, era mandado para fora. Foi na época de 
"Dancing Days", "Gabriela". Depois que a TV Globo criou o departamento internacional, em 1984, eu passei a trabalhar aí. A partir dessa data, eles começaram a fazer na própria emissora. (PEREIRA, 2000, apud RIGHINI, 2004, p. 112)

A principal função dessa atividade é a criação do foley. Esses ruídos precisam ser recriados posteriormente, uma vez que são captados e gravados junto com as vozes dos atores.

Nós pegamos uma cena com cavalos, pessoas correndo e criamos o som. Colocamos sapatos adequados, compatíveis com a cena e fazemos os passos em sincronismo. Se errarmos, voltamos a fazer, até sair de acordo. [...] nos filmes, também, quando tem uma guerra, o "cara" está correndo, e a gente ouve os passos dele. Isso não foi captado, o efeito é feito no estúdio. (PEREIRA, 2000 apud RIGHINI, 2004, p. 112)

O desenvolvimento do foley na TV Globo esteve diretamente relacionado à necessidade da emissora de adequar sua produção às exigências do mercado internacional. $\mathrm{O}$ diretor Daniel Filho contribui com esse pensamento no depoimento sobre a banda internacional de Confissões de Adolescente, produzida na década de 1990.

Eu achava que tinha a banda internacional, porque eu tinha o som sala, que era o ruído feito para complementar algum som que não fora bem captado. Pois se o microfone está na boca do ator, os passos não são bem captados, nem a mão que abre a maçaneta, nem o barulho da chave na fechadura. Todos estes ruídos têm que ser um pouco mais destacados. Eu achava que estava com isso tudo colocado quando mandei a banda internacional para o exterior. Não era o suficiente. (FILHO, D., 2005, p. 321)

Confissões de Adolescente é uma produção independente, que Daniel Filho realizou no período em que esteve afastado da TV Globo. Quando o diretor retornou à emissora, levou essa experiência para as novas produções.

A partir de Confissões de adolescente e A vida como ela é começamos a trabalhar seriamente o tratamento de som. Mas foi com A justiceira que demos um salto de qualidade. E aprendemos que o ruído é o verdadeiro trabalho de sonorização. $\mathrm{O}$ ruído também serve de música, é um som chamado de over the top, significando que o barulho usado é sempre um pouco mais alto que o normal. Pode-se destacar, assim, desde um passo até o roçar da meia de uma mulher cruzando a perna, ou o barulho de um sapato sendo tirado do pé. Quando trabalhamos esse tipo de efeito sonoro, chamamos atenção para algumas ações, pontuamos a narrativa. Essa pontuação pode, e deve ser feita também pela imagem. É assim que provocamos reações, sensações, no espectador. (FILHO, D., 2005, p. 322)

Daniel Filho destaca que é mais fácil realizar esse trabalho nas minisséries: "Por serem feitas com mais antecedência, dá para fazer um trabalho mais bem acabado". (FILHO, D., 2005, p. 322) No caso das telenovelas, a questão é sempre a falta de tempo. Segundo Guerra 
Peixe Filho, as versões originais das telenovelas não contam com o mesmo trabalho de foley desenvolvido para as versões internacionais. Segundo ele, grande parte dos ruídos é proveniente do próprio som direto, captados junto com as vozes dos atores.

\title{
2.5. Década de 1990: a estereofonia e o início da digitalização
}

Nos anos 1990 a televisão brasileira começou a transição do sistema monofônico para o estereofônico (em dois canais). Na verdade, os testes de transmissão de som estereofônico no Brasil começaram na década de 1980. Segundo uma matéria publicada na época, pelo Jornal do Brasil ${ }^{17}$, as primeiras experiências aconteceram em 1985:

\begin{abstract}
No dia 10 de abril passado, o Musical "Clip Clip" recebeu uma edição especial e foi transmitido, no início da tarde, sendo recebido por diversos televisores Trendset 20 Stéreo Espacial - o novo modelo de 20 polegadas da Philips, desenvolvido para aplicações com som estéreo - que foram instalados pelo fabricante em Shopping Centers de São Paulo e em gabinetes de autoridades locais. Segundo a Philips, o evento significou a maior inovação tecnológica da televisão brasileira desde a primeira transmissão e recepção em cores, em 1972, e coloca o país na vanguarda da tecnologia, já que a técnica só foi implantada em poucos países de grande desenvolvimento, como Japão, Estados Unidos e Alemanha. Três dias após a transmissão experimental, a Rede Globo apresentou o programa "Cassino do Chacrinha", de grande audiência, com características de som estereofônico durante toda sua duração. A recepção estéreo pôde ser acompanhada pelo público presente nos stands da Philips na Feira de Utilidades Domésticas, que ora se realiza na capital paulista, através dos televisores Trendset 20, que são dotados de seis alto-falantes e tweeters, com potência total de 12 Watts (2 X 6 W) RMS. (TV BAÚ, 2014)
\end{abstract}

Assim como as transmissões em cores, a estereofonia precisou de tempo para se consolidar. As emissoras precisaram adequar suas estruturas tecnológicas e os telespectadores tiveram que adquirir aparelhos televisores com tecnologia de som estereofônico. Nas telenovelas, a transição para a estereofonia começou a acontecer em meados da década de 1990. Segundo o sonoplasta Thanus Chalita, a possibilidade de distribuir o som nos dois canais permitiu uma nova forma de espacialização.

Tomando como referência o plano da imagem, os elementos sonoros podem ser direcionados para o lado direito ou esquerdo, "por exemplo, uma porta que está no lado esquerdo, você "puxa" no estéreo (o som) mais para o lado esquerdo, um carro que passa de

17 TV BAÚ. Disponível em: <http://tvbau.blogspot.com.br/2014/12/1985-chacrinha-inaugura-tv-estereono.html>. Acesso em: 30 nov. de 2016. 
um lado para o outro, você consegue fazer em estéreo". (CHALITA, 2016) De acordo com ele, é possível realizar essa mesma construção sonora também com as vozes:

\begin{abstract}
Quando você está olhando o monitor, se a pessoa der um grito do lado esquerdo, ou um grito do lado direito, você consegue fazer isso. Ou murmuro de vozes, por exemplo, em um bar que tenha uma galera falando do lado esquerdo, ou do lado direito, você faz essa parte em estéreo. Agora, a "coisa" é tão corrida que às vezes a gente nem tem tempo de fazer isso. O normal da voz é central. (CHALITA, 2016)
\end{abstract}

De acordo com Carlos Ronconi, as condições de recepção e exibição da televisão precisam ser levadas em consideração nas construções sonoras estereofônicas.

É muito pouco provável que você "brinque" muito com essa coisa de separação na tela. Porque a perspectiva do ponto de vista do telespectador, ou seja, a distância que ele senta da tela, a abertura do estéreo para ele na televisão, não justifica você "brincar" assim. (RONCONI, 2016)

Outra importante mudança tecnológica ocorrida na década de 1990 foi o início da transição do videotape analógico para o digital. Desde a década de 1980, alguns formatos digitais já estavam sendo testados e lançados no mercado. Em 1986, a Sony, em parceira com a Bosch, lançou o primeiro sistema de vídeo digital, o D-1. Pouco tempo depois, em 1988, a Sony e a Ampex lançaram o $D-2$, que tinha qualidade parecida ao $D$ - 1 . Apesar da excelente resolução de imagem dos dois formatos, ambos os sistemas tinham alto custo e foram mais utilizados nas atividades de finalização. Já no começo da década de 1990, a Panasonic e Matsushita lançaram o $D-3$ e, posteriormente, o $D-5$. Os novos formatos foram grandes concorrentes do $D$-1 e $D$-2, uma vez que a resolução de imagem era similar, mas os equipamentos eram bem mais acessíveis.

Contudo, foi a Sony que deu o passo definitivo para a consolidação do videotape digital. Isso ocorreu em 1993 com o lançamento do Betacam Digital. A qualidade do novo formato era praticamente a mesma dos sistemas anteriores, mas os custos e o tamanho dos equipamentos caíram pela metade ${ }^{18}$. Dessa forma, passou a ser viável que as emissoras de televisão migrassem suas produções para os sistemas digitais.

Em relação ao som, o processo de digitalização foi acompanhado pelo surgimento dos primeiros computadores dedicados a pós-produção, conhecidos como Digital Audio Workstations $(D A W)$. Na TV Globo, a primeira estação digital foi o AudioFrame,

\footnotetext{
${ }^{18}$ SCENE SAVERS. Disponível em: <http://www.scenesavers.com/content/show/tape-format-history>. Acesso em: 30 nov. de 2016.
} 
desenvolvido pela empresa WaveFrame, em meados dos anos 1980. O sistema funcionava em um computador da $I B M$ e oferecia edição, mixagem e processamento digital de som (equalizadores e efeitos). O equipamento era montado em módulos, então havia funções opcionais, como o uso de controladores MIDI (Musical Instrument Digital Interface) destinados à produção musical.

Sobre o processo de sonoplastia, a maior transformação provocada pelo AudioFrame foi o aumento do número de canais de áudio. Chalita relata: "na Studer (gravador de som multipista) a gente só tinha dois canais de música e dois canais de ruído. Com a plataforma de computador você podia fazer mais canais". (CHALITA, 2016)

A utilização dos computadores na pós-produção também foi acompanhada pela substituição dos gravadores de som analógico pelos digitais. Dentre eles, o mais conhecido era o DAT (Digital Audio Tape), lançado pela Sony em 1987. A Philips e Panasonic tentaram fazer frente à tecnologia com o DCC (Digital Compact Cassette), lançado em 1992. Porém, o $D A T$ já estava consolidado em grande parte dos ambientes profissionais.

A década de 1990 foi o início da transição dos equipamentos analógicos para os digitais. As transformações vão ser intensificadas na década seguinte, quando o processo de digitalização começa a atingir todos os âmbitos da produção televisiva.

\subsection{Século XXI: a consolidação da digitalização}

Os sistemas de vídeo Betacam Digital predominaram nas produções televisivas até meados dos anos 2000, quando novos formatos de vídeo digital, inclusive em alta definição, começaram a ganhar espaço no mercado. Dentre eles: o DVCPRO, DVCAM, HDCAM, HDV, DCVPRO HD e o XDCAM.

No caso da TV Globo, a evolução dos formatos de vídeo digital foi acompanhada pela introdução dos gravadores digitais de som multipista no processo de captação do som direto. Vimos até agora que, na produção das telenovelas, o som direto era gravado junto com a imagem, no mesmo equipamento e suporte. Mesmo com a evolução dos formatos ao longo das décadas (Quadruplex, Type C, Betacam Digital), som e imagem nunca haviam se dissociado no momento da realização das cenas. Com a introdução dos gravadores digitais multipistas, o registro do som direto passou a acontecer separadamente da imagem e cada microfone utilizado no set começou a ser gravado de forma isolada. De acordo com Rodrigo 
Meirelles, essa foi uma importante mudança em termos de qualidade:

\begin{abstract}
Com o multicanal, você consegue numa etapa de pós-produção trabalhar isoladamente lapelas, boom, microfones que você usou como escória, que seria o microfone que o pessoal chama "lá fora" de planted mic, que é um microfone plantado em algum ponto do set, um lugar estratégico. Isso ajudou muito na qualidade, porque a mixagem que você faz no set de gravação, por melhor que ela seja, o operador está fazendo de fone de ouvido e numa condição geralmente não muito adequada, pelo ruído externo e todos outros problemas que você têm que resolver ali no set de gravação. Então, aquela mixagem dificilmente vai ser melhor do que receber todos aqueles microfones gravados separadamente e trabalhar numa ilha de pós-produção com calma. (MEIRELLES, 2016)
\end{abstract}

A possibilidade de gravar isoladamente múltiplos canais promoveu o aumento do número de microfones empregados no processo de captação do som direto, em especial, a aplicação combinada de microfones direcionais com microfones de lapela.

Esse procedimento visa criar um recurso de segurança para o processo de captação, permitindo a opção pelo melhor resultado técnico e estético proporcionado por cada microfone. É válido ressaltar que, ao contrário dos microfones direcionais, os microfones de lapela têm como característica a captação da voz com menor espacialidade. Dessa forma, quando a opção é pelos microfones de lapela, há uma redução em potencial da relação entre o som captado e espaço indicado na imagem. Essa falta de espacialidade pode ser compensada posteriormente com a utilização de processadores de efeitos que acrescentam reverberação e equalização ao som captado.

Em relação à separação de som e imagem ocasionada pela introdução dos gravadores digitais no processo de captação do som, Carlos Ronconi afirma que essa modificação trouxe novos desafios para as produções em televisão.

\begin{abstract}
No meio analógico, o sincronismo não era problema porque você gravava tudo na mesma fita, ou seja, áudio e imagem estavam sempre juntos, não havia uma dissociação. No cinema, você tinha áudio gravado num gravador e a imagem gravada numa película, mesmo no meio digital esse processo ainda continua. [...] Então, preocupou-se em fazer alguns procedimentos (no cinema): usar a claquete e bater o "claque" para você marcar um ponto de sincronismo na imagem e no som. [...] No caso da TV Globo, ela se aprimorou com relação às últimas décadas. A gente começou a ter um procedimento mais parecido com o cinema. (RONCONI, 2016)
\end{abstract}

Dentre os novos procedimentos adotados pela TV Globo, Rodrigo Meirelles destaca o surgimento do produtor de áudio. Semelhante ao sound designer, esse profissional é responsável por supervisionar os processos da produção sonora da telenovela, do planejamento à finalização do som: 
Hoje eu "cuido" dos produtores de áudio, que é um cargo meio que exclusivo aqui, que não tem em muitos lugares, que é uma pessoa que acompanha desde a préprodução até o final. Então hoje, você é capaz de pensar não só em captação, mas você consegue pensar no desenho sonoro meses de antecedência ao dia da gravação. Que não adiantaria nada há muito tempo atrás, porque você não ia conseguir inserir isso de forma inteligível para o telespectador. Hoje, a gente planeja, por exemplo: “ah, vai fazer a gravação na Amazônia”, então a gente vai com uma equipe só pra fazer captação de ambientes, para serem aqueles ambientes específicos; (ou) "hoje a gente tem uma cena de computação gráfica", então a gente vê a cena como ela vai ser e planeja as gravações reais que seriam daquele ambiente. A gente faz planejamento de sound designer, então a gente também tem estúdio de foley que a gente pode gravar em sincronismo com a imagem, sons específicos daquela cena, em vários canais para ser mixado depois. A gente pode identificar num processo de gravação que uma cena não valeu e pedir para substituir os sons na pós-produção. $\mathrm{Ou}$, até mesmo, ver o material bruto dessa cena numa mídia que eu possa abrir em qualquer lugar, uma HD, ou um sistema em rede e identificar que naquela cena eu posso usar determinada ferramenta, determinado software, plugins para salvar (o som). (MEIRELLES, 2016)

Essas novas possibilidades de trabalhar o som na pós-produção se tornaram viáveis na TV Globo com a chegada de novas Digital Audio Workstations. O primeiro sistema foi o Sonic Solutions e, posteriormente, o Pro Tools. A história do Sonic Solutions teve início ainda nos anos 1980, quando uma equipe ligada a Lucasfilm's desenvolveu um projeto particular chamado SoundDroid. Em 1987, a mesma equipe iniciou a criação do Sonic Solutions. A primeira ferramenta desenvolvida foi o NoNoise, utilizada em cinema e televisão para corrigir interferências na gravação do som, como alguns tipos de ruídos e chiados (hiss, humming, pop e click). A partir da década de 1990, as funções do Sonic Solutions foram evoluindo e ele se tornou uma sofisticada ferramenta para a pós-produção de som.

Na TV Globo, o Sonic Solutions começou a ser usado no começo dos anos 2000. O primeiro impacto que ele gerou no processo de sonoplastia foi o início da substituição das fitas magnéticas pelo armazenamento em disco rígido. Rodrigo Meirelles considera que o Sonic Solutions foi a primeira grande transformação tecnológica na finalização de som da TV Globo, em seguida o Pro Tools:

A primeira quebra foi o (Sonic) Solutions, que é um software que você tem a
possibilidade de editar não linearmente o áudio, então mudou já. A gente conseguia
nessa época editar diálogos, tirar ruídos. Se tiver um ruído na captação, você
consegue limpar. Então esse tipo de coisa começou a aparecer, um trabalho bem
técnico, muito mais técnico do que artístico. E depois o Pro Tools. O Pro Tools veio
para o mercado de pós-produção como uma virada tecnológica até para Hollywood,
[...] ele ganhou o Oscar técnico por mudar o mercado de som em cinema.
(MEIRELLES, 2016) Os sistemas que deram origem ao Pro Tools já estavam em desenvolvimento desde os anos 1980: o Sound Design e o Sound Tools. Em 1991, a empresa Digidesign assumiu o 
projeto e lançou a primeira versão com o nome Pro Tools. As novas versões foram ficando cada vez mais sofisticadas e o Pro Tools começou a ganhar espaço nos segmentos de áudio profissional, da indústria fonográfica à cinematográfica. Em 2001, a Digidesign ganhou o Technical Grammy Award pelo desenvolvimento do Pro Tools. Em 2004, sob o gerenciamento do grupo Avid Technology, a Digidesign recebeu o Oscar na categoria Scientific and Technical Academy Awards, também em reconhecimento ao projeto, desenvolvimento e implantação do Pro Tools ${ }^{19}$.

Na TV Globo, o Pro Tools substituiu o Sonic Solutions e aprofundou as transformações na finalização de som da emissora. De acordo com Meirelles, uma das principais transformações foi expansão do processo de sonoplastia: O Pro Tools foi capaz de ser uma estação não linear que não só o som fosse
"editável" e reproduzido em disco rígido, mas também que o processamento fosse
em tempo real, ou seja, não era mais preciso você ter mesas de som, ou consoles
digitais caríssimos e milionários para conseguir fazer um som [...] você precisa de
uma placa (interface de áudio) e um bom computador. Então, o Pro Tools foi essa
grande virada tecnológica que na televisão teve um impacto muito grande. Aqui na
TV Globo também. Porque você sai de pouquíssimos canais que você conseguia
trabalhar para vários canais, isso mexeu em processos também. A gente passou de
"2000 e pouco" pra cá a trabalhar com três, quatro pessoas envolvidas num único
projeto de dramaturgia, na pós-produção, ou seja, então não é mais uma pessoa pra
fazer tudo. (MEIRELLES, 2016)

Nas décadas anteriores, geralmente a sonoplastia era realizada por um, ou dois sonoplastas, que eram responsáveis por todo o processo. Atualmente, uma telenovela da TV Globo conta com até quatro tipos de profissionais ${ }^{20}$ : o editor de áudio, que edita e monta o som captado nos estúdios e externas; o sonoplasta de efeitos, que cuida de todos os ruídos ambientes e efeitos sonoros das cenas; o sonoplasta de foley, que cria todos os sons provenientes das interações das personagens com os objetos e espaços cênicos; e o técnico de mixagem, que realiza a mixagem e finalização do som da telenovela, interagindo com todas as outras etapas da produção sonora. De acordo com Meirelles, esse aumento dos processos também está diretamente relacionado com a possibilidade de todos os profissionais trabalharem em rede, simultaneamente em um mesmo projeto.

Normalmente, são quatro pessoas envolvidas num projeto. Por quê? Integração em rede, o mesmo sistema, todo mundo usando o Pro Tools, cada um podendo

\footnotetext{
${ }^{19}$ AVID, 2004. Disponível em: <http://ir.avid.com/releasedetail.cfm?releaseid=357186>. Acesso em: 06 jan. de 2017.

${ }^{20}$ BANCO DE TALENTOS TV GLOBO. Disponível em: <http://talentostvglobo.com.br/area-de-captacao-epos-producao-da-globo-so-tem-profissionais-do-barulho-3/>. Acesso em: 27 jul. de 2016.
} 
compartilhar arquivos. Um sonoplasta faz uma sessão com 32 canais de efeito e manda para a mixagem final, o outro sonoplasta tem os 32 canais de efeito e mais os canais dele de música. Então esse mundo digital de workstation, no caso do Pro Tools, viabilizou processos aumentados. Em cinema já era assim, você tinha que ter um cara dedicado para cada área [...] e aí os fluxos de trabalho ficaram muito próximos, tanto cinema quanto televisão. (MEIRELLES, 2016)

Além dessas transformações ocorridas nos processos de produção, outras mudanças começaram a surgir com o início da digitalização do sistema de transmissão da televisão brasileira. Chamada de TV Digital ${ }^{21}$, a nova forma de transmitir o sinal de televisão foi inaugurada oficialmente no Brasil no dia dois de dezembro de 2007, em uma solenidade realizada na Sala São Paulo.

A TV Digital representou um ganho significativo em termos de qualidade de transmissão e recepção de som e imagem, uma vez que a transmissão digital é menos suscetível às interferências, se comparada com o sistema analógico. Além disso, transmitir o sinal de áudio e vídeo digitalizado permitiu um maior aproveitamento da banda de transmissão de $6 \mathrm{Mhz}$ destinada à cada canal aberto. Assim, as emissoras puderam aumentar a qualidade do sinal de áudio e vídeo e ainda ampliar a quantidade de informações transmitidas.

No âmbito do som, a novidade veio com a possibilidade de transmitir múltiplos canais de áudio. Como vimos anteriormente, a televisão brasileira operou no sistema monofônico até meados da década de 1990, quando as transmissões de som estereofônico (em dois canais) começaram a se consolidar no país. Com a mudança da transmissão analógica para a digital, o som $5.1^{22}$ também passou a ser uma realidade para a televisão. De acordo com Carlos Ronconi, atualmente todas as telenovelas da TV Globo são produzidas em 5.1:

Na Globo, hoje em dia, todas as novelas a gente faz em 5.1, com o ambiente em surround. Então você tem toda essa captação não simultânea, não na mesma hora que eu estou gravando a cena, eu estou gravando ambiente. Porque tem interferência, eu estou falando, tem ruído, tem um monte de coisa ambiente. Normalmente, a gente volta no mesmo lugar e grava o ambiente daquele lugar separado no outro dia, mais ou menos nas mesmas condições, para gente criar aquela atmosfera, o room tone, aquela ambientação toda. (RONCONI, 2016)

\footnotetext{
${ }^{21}$ É importante ressaltar que o uso do termo TV Digital faz menção apenas ao sistema de transmissão digital da televisão. Como vimos, a digitalização da produção televisiva brasileira ocorreu em momento distinto, com início ainda na década de 1990.

${ }^{22} \mathrm{O}$ sistema 5.1 é um padrão de som estereofônico em seis canais, divididos da seguinte forma: canal central; direito e esquerdo frontais; direito e esquerdo traseiros; e o canal destinado às baixas frequências, que é o significado do "ponto um" da nomenclatura 5.1.
} 
Nas telenovelas, o som 5.1 é mais utilizado para dar maior dimensão aos ambientes das cenas. Por meio da mixagem, os ruídos são distribuídos nos diferentes canais, o que possibilita que o telespectador tenha uma sensação sonora tridimensional dos espaços cênicos.

\begin{abstract}
Normalmente, você não tem cenas mirabolantes em novelas, cenas que exista uma "pirueta" de áudio. Então você tem basicamente uma ambientação no 5.1, você tem uma cena gravada numa praça, ou numa floresta, então você tem o ambiente no 5.1 e alguns ruídos pertinentes. Você sabe que têm uma casa, um vozerio atrás, se você está de costas para alguém, então você pode colocar isso atrás (surround). [...] Isso depende muito do sonoplasta e o tempo que o cara tem para fazer. (RONCONI, 2016)
\end{abstract}

Contudo, para o telespectador aproveitar esse tipo de construção sonora, ele precisa ter em sua casa um equipamento que seja capaz de decodificar o sinal de áudio 5.1 e reproduzi-lo em seis caixas acústicas distintas. Como os aparelhos televisores normalmente não cumprem essa função, o usuário precisa comprar um sistema (home theater) à parte para ouvir o som 5.1. A própria TV Digital se encontra em fase de consolidação no país ${ }^{23}$, de modo que é prematuro considerar que grande parte dos telespectadores esteja tecnicamente preparada para receber o som 5.1 em suas casas.

Acho que a porcentagem (de pessoas) que hoje em dia senta na frente da televisão para assistir alguma coisa em 5.1, que não são DVD e tal -, novela ou qualquer outra coisa, é muito pequena. Mas mesmo assim a gente faz, porque a gente acredita que há um mercado bom para isso, fora do Brasil também. E é um exercício para a gente, fazer toda essa dramaturgia complicada em 5.1, é um exercício bom. (RONCONI, 2016)

No caso das telenovelas, de acordo com Thanus Chalita, o desafio ainda continua sendo a falta de tempo.

\begin{abstract}
A novela é muito corrida, a gente tem um capítulo de frente de um dia só, dependendo de como esteja a novela. Não é igual ao cinema, que a gente tem muito tempo para fazer, para revisar, para refazer. [...] É tão corrido que a gente não tem nem tempo de revisar em 5.1. Quando você tem tempo, que a gente começa a sonorizar hoje e vai ao ar daqui duas semanas, ai a coisa é mais bem feita, é mais devagar, você presta mais atenção nos efeitos, nessas coisas todas, você tem um capricho para fazer. (CHALITA, 2016)
\end{abstract}

Assim como todas as mudanças tecnológicas pela qual a televisão brasileira passou, o som 5.1 necessitará de tempo para se consolidar. Na TV Globo, até o presente momento, a

\footnotetext{
${ }^{23}$ O prazo atual para o desligamento integral da televisão analógica no Brasil é 2023. A lista das cidades que terão o desligamento até 2018 estão disponíveis em: <http://redeglobo.globo.com/tv-digital/noticia/tv-globodigital-confira-cronograma-de-desligamento-do-sinal-analogico.ghtml>. Acesso em: 9 jul. de 2017.
} 
emissora ainda está se adequando ao novo sistema e convivendo com a incerteza do acesso dos telespectadores à nova tecnologia.

Por fim, em 2013, a TV Globo foi a primeira emissora brasileira a anunciar publicamente a adequação à Portaria no 354 do Ministério das Comunicações, publicada em 11 de julho de 2012, que regulamenta a padronização do volume de áudio nos intervalos comerciais da programação dos serviços de radiodifusão sonora e de sons e imagens nos termos da Lei $\mathrm{n}^{\mathrm{o}} 10.222$, de nove de maio de $2001^{24}$.

Segundo Paulo Santos, diretor de engenharia de programação e comunicação da TV Globo, atender às exigências da legislação não foi somente uma modificação em termos de exibição, mas também uma alteração em diversos âmbitos da produção da emissora:

\begin{abstract}
Sabemos que não é tecnicamente possível atender à regulamentação através apenas de um processador instalado no centro de exibição, pois isso introduziria distorções na faixa dinâmica que causariam muito mais incômodo para o telespectador que um eventual aumento de volume nos comerciais. Por isso, todo material exibido tem que seguir especificações de Loudness médio e de Loudness range, o que não é uma tarefa simples. Como ponto de partida, todos os centros de produção e pós-produção precisam ter equipamentos para medir os parâmetros de Loudness e permitir os ajustes necessários. Devemos levar em conta que em programas de entretenimento o nível de áudio em cada cena tem um impacto significativo em sua dramaticidade, por isso não usamos sistemas automáticos de processamento para esse tipo de conteúdo. (SANTOS, 2013 apud MOURA, 2013)
\end{abstract}

De acordo com Rodrigo Meirelles, a implantação do controle de Loudness na TV

Globo modificou o processo de finalização do som das telenovelas.

Depois que foi sancionada a lei do Loudness, a gente trabalha olhando mais para o Loudness do que para pico. Isso é uma mudança significativa. Porque ao invés de limitar tecnicamente o trabalho, isso faz com que a gente tenha mais range para trabalhar. [...] A gente pode ter variações que a gente não tinha antes. A gente pode se dar ao luxo de ter uma cena em que vai ter um pico em -3 LFS, muito acima de 23 LFS, um acidente alguma coisa, e depois ter uma cena mais baixinha, só diálogo. Antes não, você só tinha que garantir que não ia passar de $-10 \mathrm{~dB}$, seja a cena alta, ou a cena baixa. Agora não, desde que a média seja -23 LFS e que essa média não varie muito, que é outro parâmetro chamado Loudness Range que não pode passar de 8 , não pode variar muito, não pode ter um dinâmica de cinema. Isso não pode porque senão de noite o "cara" vai estar com a televisão ligada ali numa cena baixa e depois quando tiver um acidente ou uma explosão vai acordar o vizinho, vão reclamar, vão pegar o controle remoto toda hora [...]. Então tem um limite para isso, mas mesmo assim artisticamente você pode brincar com a dinâmica, pode ter uma cena alta e uma cena baixa. Porque com o Loudness você tem um parâmetro que não indica só quantitativamente um som, indica quantitativamente uma percepção de intensidade sonora subjetiva. Então é o volume que você ouve que está sendo

24 Informações retiradas do próprio texto da Portaria $\mathrm{n}^{\mathrm{o}} 354$, de 11 de julho de 2012. Disponível em: <http://www.abert.org.br/web/index.php/legistecnica/item/portaria-n-354-de-11-de-julho-de-2013>. Acesso em: 10 jan. de 2017. 
medido ali. Isso ajuda muito e está em todos os parâmetros de padrões de entrega para exibição da emissora, e artisticamente veio com essa contribuição. (MEIRELLES, 2016)

Na TV Globo, as adequações ao Loudness trouxeram impactos positivos para a produção sonora das telenovelas. Inicialmente, o que poderia representar um limitador para os processos criativos, na verdade, gerou um ganho em termos de range dinâmico e variação de volume. 


\section{O percurso do som nas telenovelas}

O presente capítulo apresenta um estudo sobre a trilha sonora de cinco telenovelas produzidas pela TV Globo: Pecado Capital (1975), Roque Santeiro (1985), Renascer (1993), Senhora do Destino (2004) e Avenida Brasil (2012). A partir da análise do capítulo 1 e o capítulo 100 de cada telenovela, o estudo revelou preliminarmente a existência de uma significativa diferença entre a trilha sonora de ambos os capítulos. Nas cinco telenovelas, observamos que no capítulo 1 as funções narrativas do som acontecem de forma mais equilibrada entre vozes, ruídos e músicas, ao contrário do capítulo 100, que em torno de $95 \%$ do capítulo são as vozes que assumem a centralidade da trilha sonora. Ou seja, se a média aproximada de duração dos capítulos é de 50 minutos, então as vozes protagonizam mais de 47 minutos. Dessa forma, predominam nos capítulos de número 100 as falas das personagens, que são as principais responsáveis por:

1. Levar a história adiante.

2. Comunicar fatos e informações para o público.

3. Revelar a personagem. Uma personagem pode falar de si mesma, e/ou outras pessoas podem falar sobre ela.

4. Estabelecer relações entre as personagens.

5. Comentar a ação.

6. Comentar cenas. (FIELD,1984, apud SALINAS, 1994, p. 107)

Nesse contexto, com as vozes assumindo a centralidade, os ruídos e as músicas passam a ocupar um segundo plano da trilha sonora. $O$ que não significa que ambos os elementos não estejam presentes nos capítulos de número 100. Em Senhora do Destino, por exemplo, há por volta de 30 inserções musicais. Dentre as cinco telenovelas, é a que conta com o maior número de músicas neste capítulo. Sendo que Pecado Capital tem a menor quantidade, com sete inserções musicais. No caso dos ruídos, Roque Santeiro faz um amplo uso dos efeitos sonoros. Nas outras quatro telenovelas, entretanto, os ruídos aparecem de forma mais pontual, em forma de ruídos ambientes e ruídos de sala.

Diante do exposto, visando esmiuçar as funções de cada um desses elementos sonoros nas narrativas, detalharemos individualmente as cinco telenovelas a seguir. Dedicaremos uma 
maior atenção ao capitulo 1 com o intuito de propor uma análise das construções sonoras para além da estrutura "vococêntrica" 25 que permeia o capítulo 100 de cada telenovela.

\title{
3.1. Pecado Capital (1975)
}

\author{
Autoria: Janete Clair \\ Direção: Daniel Filho \\ Sonoplastia: Roberto Rosemberg \\ Produção Musical: Guto Graça Mello \\ Coordenação Musical: João Araújo \\ Período de exibição: 24/11/1975 até 04/06/1976 \\ Horário: 20 horas \\ No de capítulos: 167
}

\subsubsection{Sinopse $^{26}$}

A telenovela Pecado Capital buscou abordar o universo suburbano carioca a partir de um triângulo amoroso formado por um taxista, um viúvo rico e uma jovem operária que sonha melhorar de vida. Carlão (Francisco Cuoco) é um motorista de táxi que vive um drama de consciência depois que assaltantes de banco em fuga esquecem em seu carro uma mala com o dinheiro roubado: não sabe se a entrega à polícia, correndo o risco de ser acusado de cúmplice do roubo, ou se usa o dinheiro para resolver seus problemas.

Carlão é noivo de Lucinha (Betty Faria), com quem tem uma relação apaixonada, mas tumultuada por brigas e ciúmes, por conta do seu machismo. Lucinha é uma jovem sonhadora que trabalha como tecelã em uma fábrica de confecções, de propriedade do industrial Salviano Lisboa (Lima Duarte). Escolhida para estrelar uma campanha publicitária, começa a

\footnotetext{
${ }^{25}$ Termo utilizado por Chion para descrever as construções sonoras centradas no som das vozes. (CHION, 2010, p.13)

26 Retirada do website Memória Globo. MEMÓRIA GLOBO. Disponível em: <http://memoriaglobo.globo.com/programas/entretenimento/novelas/pecado-capital-1-versao/tramaprincipal.htm>. Acesso em: 05 mai. 2017.
} 
fazer sucesso como modelo, com o nome de Luci Jordan. Sua circulação por ambientes mais sofisticados, aliada à rudeza de Carlão, afasta-a da realidade do subúrbio, levando-a a se envolver com Salviano, homem gentil e sensível, cujos modos contrastam com os do exnoivo.

Os dois se apaixonam, e Lucinha é obrigada a enfrentar a desconfiança e a hostilidade dos filhos do empresário para concretizar seu amor: além de não aprovarem a relação do pai com uma mulher mais jovem e de outra classe social, eles estão certos de que a moça está interessada apenas no dinheiro da família.

Carlão não se dá conta de que não é o dinheiro, mas a distância cultural, representada por valores conflitantes, que o separa de seu amor. Para provar à ex-namorada que é capaz de competir com Salviano, ele compra uma frota de táxis com a quantia do assalto e dá início a sua ascensão social como empresário suburbano, ajudando moradores de sua comunidade. Passa a ser chamado de "Rei do Méier". Penalizado, casa-se com Eunice (Rosamaria Murtinho), involuntariamente envolvida no assalto ao banco e que, com o sumiço da mala com o dinheiro, corre o risco de ser presa como cúmplice do roubo. O ex-taxista, porém, começa a gastar muito dinheiro. Para não perder o status, e por conta de sua obsessão por Lucinha, envolve-se em transações ilícitas com Sandoval (Alfredo Murphy), um perigoso marginal, que passa a ameaçá-lo, cobrando a dívida de um empréstimo.

No final da trama, Carlão decide ficar com Eunice. Redimido, vende a frota de táxis para devolver o dinheiro do assalto e, em seguida, entregar-se à polícia. Sandoval (Alfredo Murphy), porém, sequestra e tortura Elisete (Leina Krespi), que acaba revelando os planos do irmão. Carlão deixa a mala com o dinheiro nas obras de implantação do metrô do Largo da Carioca, no Centro do Rio, e avisa à polícia, sem saber que é seguido por Sandoval e seu comparsa. Ao avistar os bandidos, Carlão corre atrás dos dois e consegue recuperar a mala, mas é morto a tiros. Os bandidos são presos. Lucinha e Salviano se casam no mesmo dia.

\subsubsection{Considerações sobre a trilha sonora}

Pecado Capital foi a primeira telenovela em cores exibida pela TV Globo na faixa de horário das 20 horas. A telenovela inovou o horário nobre da emissora, tanto em relação ao novo padrão de imagem, quanto no que diz respeito à temática que procurou dialogar com a vida urbana do Rio de Janeiro, sobretudo nas regiões mais periféricas da cidade. A proposta 
foi buscar uma aproximação com a realidade por meio de construções audiovisuais calcadas na verossimilhança.

\footnotetext{
Segundo Daniel Filho, Boni chegou a pedir que os primeiros capítulos da novela fossem regravados, porque achava que o público se assustaria com as doses maciças de realismo, especialmente na reconstituição do subúrbio carioca. Para a felicidade do diretor - desesperado ante a perspectiva de ter que refazer tudo -, Boni reconsiderou sua opinião e voltou atrás. (MEMÓRIA GLOBO, 2013)
}

No primeiro capítulo da telenovela, a busca por uma maior realidade na tela pode ser percebida na grande quantidade de cenas realizadas fora dos estúdios da emissora. Ao invés das cidades cenográficas, Pecado Capital recorreu à própria cidade do Rio de Janeiro: ruas e avenidas; fachadas da fábrica de tecidos América Fabril, em Deodoro; a Boate 706 e o restaurante Mário, no Leblon; a estação de trens da Central do Brasil; entre outros espaços.

É importante destacar que, conforme vimos no capítulo anterior, os equipamentos portáteis de televisão começaram a ser efetivamente utilizados nas telenovelas a partir da década de 1970. Dessa forma, a produção de Pecado Capital já contava com a tecnologia em 1975, o que viabilizou a realização de uma grande quantidade de cenas em locações espalhadas pela cidade do Rio de Janeiro.

Com as gravações acontecendo fora dos ambientes dos estúdios, novas sonoridades foram incorporadas à trilha sonora da telenovela. A começar pela espacialidade das vozes das personagens, que transmitem as características acústicas dos espaços onde foram captadas. $\mathrm{O}$ exemplo mais emblemático ocorre na cena do refeitório na fábrica Centauro. Lucinha e uma colega de trabalho estão almoçando no refeitório. Nélio passa pelo local acompanhado de um cinegrafista. Lucinha o aborda e questiona sobre os motivos da filmagem que aconteceu há poucos minutos atrás na linha de produção da fábrica. Nélio explica que as imagens são para o filme comercial da loja Centauro e aproveita para elogiar Lucinha e entregar um cartão da agência de publicidade onde ele trabalha. A gravação dessa cena aconteceu nas dependências do magazine Hélio Barki, uma das locações utilizadas pela telenovela (MEMÓRIA GLOBO, 2013). Durante o diálogo das personagens, ouvimos também a reverberação das vozes que se propagam pelo ambiente da locação. Além de comunicar verbalmente a história, as falas das personagens permitem a compreensão do formato, dimensão e materiais que constituem o espaço do refeitório. Assim, a espacialidade presente no som da voz contribui com a sensação de realidade buscada pela telenovela.

A proposta de uma construção audiovisual verossimilhante também pode ser observada na valorização dos ruídos ambientes. Logo na primeira cena da telenovela, por 
exemplo, vemos a fachada da loja Centauro em uma esquina da cidade e uma grande quantidade de pessoas e automóveis transitando pelas ruas. A construção sonora da cena acontece exclusivamente por meio dos ruídos ambientes, que criam um adensamento sonoro a partir do som proveniente dos automóveis. Salviano caminha pela calçada e um movimento de zoom in acompanha a entrada do personagem na loja Centauro. Quando há o corte da imagem externa da cidade para o interior da loja, temos uma transição sonora que alterna dos intensos ruídos da cidade para o silencioso ambiente da loja. Essa oposição sonora marca a troca das cenas, guiando a leitura dos diferentes espaços da narrativa. Assim, os ruídos ambientes criam o que Flôres denomina de "cenografia sonora", auxiliando a "compreensão da espacialidade de um determinado cenário pelo espectador". (FLÔRES, 2013, p.128)

Além de construírem sonoramente os espaços cênicos, os ruídos protagonizam sequências de Pecado Capital. Citamos, anteriormente, o diálogo entre Lucinha e Nélio no refeitório da fábrica Centauro. A cena que precede esse diálogo acontece na linha de montagem da fábrica, quando Nélio e um cinegrafista registram as imagens do processo de produção das roupas. A cena começa com uma sequência de planos de imagem de máquinas de costuras em pleno funcionamento. Não há vozes e músicas, somente os ruídos provenientes da movimentação dos equipamentos trabalhando. À medida que a montagem alterna planos de imagens das máquinas trabalhando, ouvimos ruídos com diferentes texturas e tonalidades. $\mathrm{O}$ arranjo sonoro gerado a partir do encadeamento sucessivo dos ruídos cria uma espécie de "sinfonia" das máquinas de costuras, que rege toda ação que se desenvolve no ambiente industrial.

Ao final da cena, a valorização dos ruídos é levada a cabo. Depois de percorrer o processo de produção, Nélio e o cinegrafista param diante da máquina operada por Lucinha. O cinegrafista começa a filmar Lucinha e ela sorri para a câmera. Nélio gesticula pedindo que Lucinha continue trabalhando. Ela não entende e mantém os olhares para a câmera. Nélio novamente tenta orientá-la, mas dessa vez falando com ela. No entanto, não ouvimos a voz de Nélio, vemos somente os movimentos dos lábios do personagem. A ausência do som da voz intensifica a presença dos ruídos, reforçando a sensação do alto volume sonoro produzido pelo trabalho incessante das máquinas de costuras. A poluição sonora do ambiente fabril impede que Lucinha ouça as palavras ditas por Nélio. A construção sonora da cena proporciona a mesma sensação para o telespectador que, assim como Lucinha, só consegue compreender Nélio por meio da leitura de sua gesticulação.

Em contraposição aos ruídos intensos e incessantes das máquinas de costura, temos a valorização da sensação de silêncio na cena em que Salviano aguarda os filhos para o jantar 
de aniversário. Enquanto Salviano caminha em volta da mesa de jantar, ouvimos os ruídos de sala compostos pelos passos do personagem. Os poucos elementos sonoros criam a sensação de silêncio e reforçam o ambiente vazio da casa de Salviano. A cada passo, temos a sensação de que o vazio também toma conta do personagem, que se demonstra solitário com a ausência dos filhos. Repentinamente, o silêncio é interrompido pelo som do telefone que toca na sala ao lado. A quebra do silêncio simboliza a própria esperança de Salviano de encontrar os filhos. No entanto, a ligação telefônica é de Vitória avisando que não irá comparecer. Salviano volta a caminhar pela casa e o silêncio é retomado. Dessa forma, a presença e ausência dos filhos são polarizadas respectivamente pela maior ou menor quantidade de ruídos na cena. Salviano se dá conta de que ninguém irá comparecer à comemoração do seu aniversário e o personagem decide jantar sozinho. Nesse momento, há a inserção de uma música composta por instrumentos de corda e sopro. O andamento lento do tema orquestral e a melodia executada por um violino reforçam a solidão de Salviano, que tem apenas os funcionários como companhia.

No final da cena, Salviano está sentado à mesa sozinho. Um movimento de zoom in aproxima seu rosto lentamente. Começamos a ouvir o som interno ${ }^{27}$ do personagem, composto por vozes que ecoam suas lembranças. São as falas de seus filhos ainda crianças, conversando em volta da mesa de jantar. O som acessa as memórias afetivas do personagem e passa a transmitir o estado psicológico do mesmo. A nostalgia toma conta de Salviano, que se lembra dos tempos em que a mesa de jantar ficava completa com a presença dos filhos.

No âmbito da trilha musical, Pecado Capital foi a primeira telenovela da TV Globo a utilizar canções prestes a serem lançadas pelas gravadoras. Para uma melhor compreensão da evolução do uso das canções nas telenovelas, precisamos voltar um pouco mais na história. Nas décadas de 1940 e 1950, as radionovelas viviam seu apogeu e, segundo o maestro Júlio Medaglia, elas levavam para a casa dos brasileiros uma "sonoplastia exclusivamente de música clássica e a sua maior parte da música de vanguarda do século 20”. (MEDAGLIA apud RIGHINI, 2004, p. 44) Com a transposição do gênero para a televisão, as telenovelas herdaram a mesma característica, utilizando as discotecas das emissoras de rádio. Assim, ao longo da década de 1950, as músicas instrumentais predominaram nas trilhas musicais das telenovelas. Foi a partir dos anos 1960 que algumas experiências significativas com temas cantados começaram a acontecer.

\footnotetext{
${ }^{27}$ Chion utiliza o termo som interno para designar os sons que correspondem tanto aos aspectos físicos, ou psicológicos de uma personagem, podendo ser: sua respiração, batimentos cardíacos ou vozes de suas recordações. (CHION, 2008, p. 64)
} 
Em dezembro de 1964, a TV Record levou ao ar a novela, Prisioneiro de um sonho, de Roberto Freire, que continha em sua trilha o samba "Tereza tristeza", de um certo Francisco Buarque de Holanda, que viria a se tornar conhecido apenas dois anos mais tarde, ao lançar seu primeiro álbum e vencer o II Festival de Música Popular Brasileira [...] Em, 1965, na TV Excelsior, Agnaldo Rayol gravou a música-tema de uma novela por ele protagonizada, $O$ caminho das estrelas, e a dupla Zaé Júnior e Teotônio Pavão compôs quatro temas com letra, dois para A deusa vencida [...] e dois para A grande viagem. (BRYAN; VILLARI, 2014, p. 28)

No final da década de 1960, Salathiel Coelho também se destacou por ter realizado experiências com canções nas telenovelas da TV Tupi. A primeira delas foi com o samba Nem vem que não tem, de Wilson Simonal, utilizado em Os Rebeldes, em 1967. No ano seguinte, o sonoplasta repetiu a dose na telenovela Antonio Maria, priorizando temas portugueses. As canções foram compiladas em um álbum idealizado e produzido pelo próprio Salathiel Coelho, obtendo uma vendagem expressiva. Foi o primeiro disco em formato long-play contendo a trilha musical de uma telenovela específica. (BRYAN; VILLARI, 2014, p. 41)

Contudo, a presença das canções nas telenovelas foram exceções ao longo de quase toda a década de 1960. Somente a partir de Beto Rockfeller ${ }^{28}$, exibida em 1968 pela TV Tupi, que essa história começou a mudar definitivamente. Com a proposta da telenovela de se aproximar do cotidiano do telespectador, o produtor musical Cayon Gadia abriu mão dos temas orquestrais para compor uma trilha musical com sucessos do pop e do rock. Dessa forma, foram as composições do Beatles, Bee Gees, Roberto Carlos, entre outros, que desencadearam uma nova relação entre canção e telenovela.

Era comum as músicas tocarem inteiras enquanto os personagens caminhavam ou
pensavam, tornando a cena praticamente um videoclipe, e o apelo popular dessas
cenas era tamanho que a forma como a música as apoiava tornou-se modelo para as
novelas seguintes. Curiosamente, além dos compactos simples com as músicas-
tema, a Philips lançou um com Luis Gustavo falando textos escritos por Bráulio
Pedroso, ao som de duas músicas gravadas com arranjo e regência do maestro José
Briamonte: "F... comme femme", de Adamo, na qual Beto se despede da mulher
amada, e "Beto Rockfeller", de Briamonte, na qual Beto paquera uma garota.
(BRYAN; VILLARI, 2014, p. 52)

Impulsionada pelo sucesso alcançado por Beto Rockfeller, a TV Globo passou a investir nas trilhas musicais. Em 1969, Véu de Noiva foi a primeira telenovela da emissora a apresentar músicas exclusivamente compostas para sua trama. O produtor musical Nelson

\footnotetext{
${ }^{28}$ A telenovela Beto Rockfeller é considerada um marco da modernização do gênero. Criada por Cassiano Gabus Mendes e escrita por Bráulio Pedroso, Beto Rockfeller rompeu com os melodramas "capa e espada" que, até então, predominavam nas telenovelas. Ao invés das ambientações em épocas e países distantes, a história acontecia no presente, em meio à cidade de São Paulo. Os personagens falavam tal como as conversas cotidianas, utilizando uma fala coloquial e gírias, em detrimento da impostação vocal herdada do rádio e, principalmente, do teatro.
} 
Motta, em parceria com a Philips, utilizou os artistas da gravadora para criar a trilha musical da telenovela. As canções foram compostas por Vinicius de Moraes, Chico Buarque, Caetano Veloso, Antônio Adolfo e Tibério Gaspar; e as músicas instrumentais por César Camargo Mariano, Roberto Menescal e Dori Caymmi.

Em 1970, a TV Globo repetiu o formato em Irmãos Coragem. Nelson Motta foi novamente o responsável por montar a trilha musical da telenovela, que contou com nomes como Jair Rodrigues, Tim Maia, Denise Emmer e Maysa. A própria atriz Regina Duarte - que vivia a personagem Rita na telenovela - interpretou uma composição de Paulino Machado, Minhas tardes de sol. O tema de Irmãos Coragem foi composto por Nonato Buzar e Paulinho Tapajós, e interpretado por Jair Rodrigues.

Esse sistema perdurou nas telenovelas da TV Globo até Pecado Capital, quando Guto Graça Mello - com a coordenação musical de João Araújo - colocou em prática na emissora um novo ${ }^{29}$ padrão de montagem das trilhas musicais. De acordo com Mello:

Eu tinha a intuição de que, se tivesse acesso ao enredo, à dramaturgia, ao que iria acontecer na novela, e tendo acesso ao que todas as gravadoras estavam produzindo, os resultados finais seriam muito melhores, inclusive comercialmente. Com a sinopse, o produtor iria procurar as gravadoras e pesquisar o que elas estavam produzindo. Escolheria músicas inéditas, ou não, e faria a adequação. Com isso, a emissora ficaria por dentro do que acontecia no cenário musical brasileiro. (FILHO, 2001, p. 331)

Salvo a canção Pecado Capital (tema de abertura composto por Paulinho da Viola), a trilha musical da telenovela foi toda "garimpada" nas gravadoras. De acordo com o diretor Daniel Filho, o processo de seleção das canções levou em consideração à própria proposta da telenovela:

$\mathrm{Eu}$ queria que a novela fosse malandra, suburbana e, ao mesmo tempo, profundamente romântica. A partir desse briefing, Guto foi me trazendo músicas fantásticas, como por exemplo, aquela do Martinho da Vila que diz "Você não passa de uma mulher", que eu imediatamente dei para Lucinha, personagem da Betty Faria, e que era praticamente o ponto de vista do Carlão sobre a namorada [...] Para Francisco Cuoco (Carlão), precisava de uma música que as pessoas cantassem na

\footnotetext{
${ }^{29}$ Segundo Bryan e Villari: “o método de seleção musical adotado por Guto Graça Mello remete ao de Cayon Gadia a partir de Beto Rockfeller - tanto que as trilhas de novelas da TV Tupi passaram, desde então, a conter faixas de diversos intérpretes, em sua maior parte preexistentes e escolhidas por combinarem com os personagens em letras e melodias. A diferença era que as trilhas nacionais da TV Globo passaram, então, a reunir fonogramas de várias gravadoras - o que não era o caso das trilhas da TV Tupi, que continham apenas fonogramas da gravadora que as lançava - e com vocação comercial predeterminada - o que a princípio, não era prioridade para os executivos da TV Tupi, e, quando passou a ser, era tarde, pois, mesmo sendo a única emissora a competir na década de 1970 com a TV Globo no gênero, sua crescente crise administrativa e financeira entibiou a parte artística”. (BRYAN; VILLARI, 2014, p. 182)
} 
rua, nos botequins. A música veio pronta para minha mão, "Juventude transviada", do Luiz Melodia. (FILHO, 2000, p. 330)

Os temas de personagens são uma das características marcantes da utilização das canções nas telenovelas. No primeiro capítulo de Pecado Capital, por exemplo, o tema de Lucinha conduz o percurso da personagem do trabalho até casa dela. A sequência começa na saída da fábrica Centauro. Lucinha está acompanhada de uma colega de trabalho, ambas saem do prédio da empresa ao lado de várias outras funcionárias. O vozerio proveniente das conversas constrói a movimentação do horário da saída no entorno da fábrica. Além dos ruídos ambientes, ouvimos o tema de Lucinha, Você não passa de uma mulher, que nesse trecho é executado de forma instrumental. Lucinha aguarda uma carona de Carlão, que não aparece para buscá-la. Ela decide ir embora junto com uma colega de trabalho. A partir desse ponto, ouvimos os versos cantados por Martinho da Vila:

\footnotetext{
Mulher preguiçosa, mulher tão dengosa, mulher

Você não passa de uma mulher (ah, mulher)

Mulher tão bacana e cheia de grana, mulher

Você não passa de uma mulher (ah, mulher)

Você não passa de uma mulher (ah, mulher)

Você não passa de uma mulher

Olha que moça bonita

Olhando pra moça mimosa e faceira

Olhar dispersivo, anquinhas maneiras

Um prato feitinho pra garfo e colher

Eu lhe entendo, menina

Buscando o carinho de um modo qualquer

Porém lhe afirmo, que apesar de tudo

Você não passa de uma mulher (ah, mulher)

Você não passa de uma mulher

Olha a moça inteligente

Que tem no batente o trabalho mental

Q.I. elevado e pós-graduada

Psicanalizada, intelectual

Vive à procura de um mito
}

A sequência tem aproximadamente 2 minutos. Lucinha e a colega percorrem um longo trajeto pela cidade do Rio de Janeiro: interior do vagão do trem, plataforma da estação, saída da estação, ruas da cidade e fachada do prédio onde ela mora. A presença dos ruídos ambientes orienta a troca dos diferentes espaços, transmitindo a movimentação do ambiente urbano por onde elas caminham. A canção fornece a unidade e o ritmo narrativo, conduzindo as ações das personagens, ao passo que a letra cantada por Martinho da Vila introduz a temática do machismo, abordada na telenovela por meio do relacionamento entre Lucinha e Carlão. 
Além das canções, foram selecionadas três músicas instrumentais para compor a trilha musical de Pecado Capital: Makaha, de Márcio Montarroyos; Melô da cuíca, composta por José Roberto Bertami e Alexandre Malheiros, gravada pelo grupo Azimuth; e $O$ boêmio, composta por Anacleto de Medeiros e Catulo da Paixão Cearense, gravada pelo conjunto de choro Época de Ouro.

A música $O$ boêmio é um dos temas do núcleo narrativo de Carlão. No primeiro capítulo a música rege a introdução do personagem na história. A sequência começa com imagens aéreas de ruas e avenidas do Rio de Janeiro. Os ruídos provenientes do vai e vem dos automóveis constrói a movimentação intensa do ambiente urbano. Ouvimos as primeiras notas da música $O$ Boêmio, executadas por um cavaquinho e violão. O agogô e o chocalho marcam o ritmo do samba. Vemos o táxi de Carlão trafegando no trânsito intenso da cidade. No interior do veículo a foto de Lucinha está fixada logo acima do rádio. Carlão dirige em meio ao congestionamento. Uma pessoa faz um sinal, ele encosta próximo à calçada e o passageiro embarca no táxi. A intensidade da música diminui, criando uma passagem para o início do diálogo. Após Carlão reclamar do trânsito e do forte calor, a música assume novamente a centralidade da trilha sonora, conduzindo o movimento do táxi pelas ruas da cidade.

O táxi chega ao destino, o passageiro desembarca do veículo e Carlão segue em frente. Um corte seco de imagem alterna do exterior da cidade para o interior de uma loja, onde vemos o personagem caminhando em meio aos cabides de roupas. Nessa transição de cena, existe uma elipse temporal que suprime trechos do percurso de Carlão até loja. Mas a permanência da música conecta a ação do personagem, estabelecendo a continuidade da narrativa. No interior da loja, Carlão conversa com uma vendedora e a música é atenuada até cessar por completo. Carlão flerta com a vendedora enquanto compra um vestido para a própria namorada, Lucinha. Após realizar a compra, o personagem deixa a loja. Novamente, um corte seco alterna do interior da loja para o táxi de Carlão trafegando por uma rua da cidade. A conexão entre as duas cenas é realizada por meio da retomada da música $O$ Boêmio, que mantém o foco narrativo em torno de Carlão.

Carlão encosta o táxi próximo à calçada e um passageiro desembarca. Ele coloca uma placa escrita "almoço" no painel do veículo. A partir desse ponto, uma montagem paralela passa a intercalar a narrativa de Carlão com a cena de um assalto a banco. A transição ocorre logo após Carlão colocar a placa no interior do táxi, quando vemos uma mulher no interior de um veículo, que aparenta estar impaciente à espera de alguém. A transição entre as duas cenas é conduzida por uma troca de músicas, que introduz na narrativa um arranjo composto 
predominantemente por notas musicais graves. A tensão proveniente da harmonia dissonante da música anuncia a entrada do assaltante em cena, que sai às pressas do banco e entra no veículo onde está a mulher. $\mathrm{O}$ assaltante aponta uma arma para a mulher e a obriga a iniciar uma fuga junto com ele. No momento em que ela arranca com o veículo, o ruído proveniente do atrito do pneu derrapando no asfalto cria o ponto de transição para o início de uma nova música. $\mathrm{O}$ andamento mais acelerado da música passa a conduzir o ritmo da montagem, que intercala uma grande quantidade de planos de imagem do veículo em alta velocidade pelas ruas da cidade.

Após o início da fuga, o foco narrativo retorna à Carlão. A música $O$ Boêmio é retomada e o foco da ação volta para o personagem. O andamento mais lento da música desacelera o ritmo das imagens. Carlão circula por uma rua da cidade e se recusa a pegar um passageiro devido ao horário de almoço. Uma troca de música faz novamente a transição para cena da fuga. O clima fica mais tenso com a presença da polícia, que é acentuada pelo ruído agudo da sirene da viatura. A música gera a tensão e conduz o ritmo narrativo, que acelera com a montagem rápida dos planos de imagem. O assaltante e a mulher tentam despistar a viatura da polícia e entram em um táxi. Coincidentemente, o táxi é do próprio Carlão, que é obrigado pelo assaltante a dirigir o veículo. A ausência da música $O$ Boêmio no momento em que Carlão aparece na cena rompe com o padrão desenvolvido ao longo da sequência. E a continuidade da música que vinha conduzindo a fuga reforça a passagem do personagem para o plot do roubo ao banco.

Na última cena do primeiro capítulo, Carlão se recupera do susto vivido durante a fuga com o assaltante. Do lado de fora de casa, enquanto o personagem averigua os danos no táxi, ouvimos um samba marcado por um arranjo de cuíca. Carlão entra no automóvel para limpálo e, ao se virar para trás, vê uma mala preta em cima do banco do passageiro. Nesse instante, o samba cessa abruptamente, criando um silêncio repentino na cena. Essa transição sonora cria uma interrupção na leitura da cena, chamando a atenção para a imagem da mala. Carlão pega a mala e a coloca no banco da frente. Ele abre a mala, olha o seu interior e a câmera aproxima do seu rosto com um zoom in. A sensação de silêncio colabora com o suspense da cena por alguns instantes, mas logo é interrompido por um arranjo de cuíca que atua como anunciador do conteúdo da mala. Finalmente, vemos uma grande quantidade de dinheiro no interior da mala. O arranjo de cuíca faz a transição para a música Melô da Cuíca. Os acordes dissonantes da música sustentam o suspense da cena final do capítulo: afinal, Carlão ficará com o dinheiro do assalto ou entregará à polícia? 
No capítulo 100, observamos uma estrutura musical semelhante ao capítulo 1. As músicas são utilizadas principalmente como condutoras psicológicas, indicando, a partir de códigos preestabelecidos, as intenções dramáticas das cenas. Assim, as inserções musicais atuam no âmbito das emoções, colaborando com a alegria, tristeza, suspense e romance da história. Tal como Gorbman aponta ao descrever o modelo clássico do uso das músicas no cinema hollywoodiano dos anos 1950, em que a "trilha musical pode definir sentimentos específicos e enfatizar emoções particulares sugeridas na narrativa, mas em primeiro lugar e, acima de tudo, é um significante da própria emoção”. (GORBMAN, 1987, p. 73, tradução nossa)

Dentre outras funções discutidas por Gorbman, destacamos também a capacidade da música de estabelecer a continuidade narrativa, fornecendo o ritmo e criando as transições entre as cenas. (GORBMAN, 1987) Essa é uma função presente no capítulo 1 que também ecoa no capítulo 100. Nos trechos em que não há vozes, por exemplo, as músicas assumem o primeiro plano sonoro e passam a conduzir as imagens. Isso ocorre principalmente nas mudanças de cenas, quando a música faz a passagem do final de uma ação para o início de outra que, na maioria das vezes, ocorre em outro tempo e espaço narrativo. Dessa forma, a música é por excelência o que Chion denomina de "placa giratória espaço-temporal":

\footnotetext{
Isto significa que a posição particular da música consiste em não estar submetida a barreiras de tempo e de espaço, contrariamente aos outros elementos visuais e sonoro, que devem estar situados relativamente à realidade diegética e a uma noção de tempo linear e cronológico. [...] Este privilégio não lhe pode ser disputado por nenhum outro elemento sonoro do filme. Fora do tempo e fora do espaço, a música comunica com todos os tempos e com todos os espaços do filme, mas deixa-os existirem separada e distintamente. (CHION, 2011, p. 68)
}

Em relação aos ruídos, no capítulo 100 eles participam com menor intensidade da narrativa. Isso se deve, em grande parte, à ausência de cenas realizadas no espaço urbano do Rio de Janeiro, que no capítulo 1 são as grandes responsáveis pelo protagonismo dos ruídos ambientes.

Por fim, é importante destacar que Pecado Capital emplacou sete canções no rádio, dentre elas: Moça, de Wando, que foi a mais tocada em 1975, e Juventude transviada, de Luiz Melodia, que foi a mais tocada em 1976. (BRYAN; VILLARI, 2014, p. 177) De acordo com Bryan e Villari:

O sucesso da novela colaborou para o interesse em torno das músicas e vice-versa. Assim se entre 1971 e 1974 os temas nacionais de novelas quase inexistiam entre as cem músicas mais tocadas anualmente nas rádios, em 1975 eles não apenas 
dispararam, como suplantaram os temas internacionais. E o excelente resultado da música nacional levou o movimento brazilian singers a decrescer até quase se extinguir na década seguinte, possibilitando que seus intérpretes pudessem enfim cantar e se apresentarem em português. [...] Guto tornou-se, então, o diretor musical da teledramaturgia da TV Globo e um novo padrão foi estabelecido: as músicas até então compotas para novelas, que pouco interessavam às rádios e que mesmo nas novelas não tinham muito relevo, davam lugar a faixas extraídas dos lançamentos dos músicos de maior expressão do momento - faixas que interessariam por si só às rádios, e que, ao serem associadas a tramas de sucesso, tornavam ainda maior o interesse do grande público. (BRYAN; VILLARI, 2014, p. 177-178)

A partir de Pecado Capital, o sistema de selecionar músicas nos catálogos das gravadoras se consolidou na TV Globo. Com isso as canções nacionais passaram a ter cada vez mais espaço nas trilhas musicais das telenovelas e a TV Globo passou a atuar mais intensamente na indústria fonográfica, tanto por meio da articulação com o rádio para a circulação das canções no território brasileiro, quanto a partir da venda de discos por meio do selo Som Livre criado pela emissora.

\title{
3.2. Roque Santeiro (1985)
}

\author{
Autoria: Dias Gomes \\ Coautoria: Aguinaldo Silva \\ Direção-geral: Paulo Ubiratan \\ Sonoplastia: Aroldo Barros \\ Efeitos Sonoros: Jair Pereira \\ Produção musical: Mariozinho Rocha \\ Trilha incidental: Waltel Branco, Radamés Gnatalli e Marcio Pereira \\ Período de exibição: 24/06/1985 até 22/02/1986 \\ Horário: 20 horas \\ No de capítulos: 209
}




\subsubsection{Sinopse $\mathrm{S}^{30}$}

Roque Santeiro apresenta uma sátira da exploração política e comercial da fé popular. A história acontece na cidade fictícia de Asa Branca, onde os moradores vivem em função dos supostos milagres de Roque Santeiro (José Wilker), um coroinha e artesão de santos de barro que teria morrido como mártir ao defender a cidade do bandido Navalhada (Oswaldo Loureiro). O falso santo, porém, reaparece em carne e osso 17 anos depois, ameaçando o poder e a riqueza das autoridades locais.

No dia em que o bando de Navalhada invadiu Asa Branca, todos os habitantes fugiram apavorados, enquanto Roque Santeiro desapareceu, sendo dado como morto. Logo após o incidente, uma menina que conseguiu sobreviver disse ter visto o rapaz em uma visão. A notícia se espalhou, e Roque, tido como salvador da garota, foi santificado. Uma estátua em homenagem ao herói foi erguida em praça pública, e a população logo passou a lhe atribuir curas e milagres.

A volta de Roque Santeiro e o reconhecimento de que tudo não passou de uma farsa significaria o fim do mito, prejudicando os interesses de todos os beneficiários da mentira, e também colocando em risco a sustentação da cidade.

Os representantes das forças políticas, religiosas e econômicas de Asa Branca se dividem entre os que defendem que a verdade deve ser revelada e os que querem manter o falso milagre porque precisam dele para sobreviver. Entre os que se sentem ameaçados com a volta de Roque estão o conservador padre Hipólito (Paulo Gracindo), o prefeito Florindo Abelha (Ary Fontoura), o comerciante Zé das Medalhas (Armando Bógus) - principal explorador da imagem do santo - e o temido fazendeiro Sinhozinho Malta (Lima Duarte), amante da pretensa viúva do santo, a fogosa Porcina (Regina Duarte). Incentivada por Sinhozinho, Porcina - que sequer conhecia Roque - espalhou a mentira de que havia se casado com o santeiro, e acabou se transformando em patrimônio da cidade. Quando conhece Roque, apaixona-se de fato por ele, formando com Sinhozinho e o santo o principal triângulo amoroso da trama.

A chegada de Roque Santeiro também atinge a vida de outra moradora de Asa Branca: Mocinha (Lucinha Lins), a verdadeira noiva de Roque. Mocinha nunca se conformou com o

\footnotetext{
30 Retirada do website Memória Globo. MEMÓRIA GLOBO. Disponível em: <http://memoriaglobo.globo.com/programas/entretenimento/novelas/roque-santeiro/trama-principal.htm>. Acesso em: 05 mai. 2017.
} 
desaparecimento do noivo e esperou anos por seu amor, mantendo-se casta. Ao revê-lo, sua paixão reacende e ela se enche de esperança. Filha do prefeito e da beata Dona Pombinha (Eloísa Mafalda), ela é cortejada pelo soturno professor Astromar Junqueira (Rui Resende). Com o retorno do amado, Mocinha finalmente se entrega a ele, liberando sua sexualidade reprimida. Mas a personagem enlouquece ao término da história, perambulando pela cidade vestida de noiva.

No capítulo final da novela, após muitas tensões e reviravoltas, Roque Santeiro concorda em deixar a cidade. O mito não é desfeito, e o povo de Asa Branca segue acreditando em seu santo. A dúvida sobre com quem Porcina vai ficar perdura até a última cena, que lembra o clássico Casablanca (1942), de Michael Curtiz. A viúva não sabe se embarca com Roque num avião ou continua na cidade ao lado de Sinhozinho Malta. Diferentemente da personagem de Ingrid Bergman no filme, porém, ela decide ficar com o coronel.

\subsubsection{Considerações sobre a trilha sonora}

Roque Santeiro foi a estreia de Dias Gomes no horário nobre da TV Globo. Até então, o autor costumava escrever para a faixa de horário das 22 horas, que normalmente a emissora destina as telenovelas com caráter mais experimental. Dentre algumas experiências bem-sucedidas de Dias Gomes podemos citar: O Bem-Amado (1973) e Saramandaia (1976) telenovela que autor utilizou o realismo fantástico para driblar a censura da ditadura militar. Mesmo diante das ações dos censores, que lhe custavam dezenas de páginas cortadas, Dias Gomes não abriu mão de colocar nas telenovelas críticas à sociedade brasileira. Foi justamente por esse motivo que a primeira versão de Roque Santeiro - que seria exibida em 1975 - foi proibida pelos militares. Os censores descobriram que a telenovela era uma adaptação da peça teatral $O$ Berço do Herói, que já havia sido censurada anteriormente. Dez anos depois, com o processo de abertura política, a TV Globo conseguiu exibir Roque Santeiro.

Ao contrário de Pecado Capital, que propõe uma aproximação com a realidade, a trama de Roque Santeiro se desenvolve por meio da paródia. A cidade fictícia de Asa Branca funciona como um microcosmo do Brasil, onde vivem personagens caricatos que fornecem o tom de cômico da telenovela. Nas narrativas realistas, a tendência é que os personagens falem 
de forma mais verossímil, adotando como referência a própria linguagem coloquial da vida cotidiana. No caso de Roque Santeiro, as vozes criam uma espécie de "caricatura sonora", que atuam como elemento de reforço para os personagens. Sinhozinho Malta, por exemplo, articula as falas acentuando os fonemas em tons graves. No código audiovisual, os sons graves são amplamente utilizados para promover tensão, medo e suspense. No gênero terror, por exemplo, as baixas frequências reforçam a presença do malfeitor na narrativa. No caso de Sinhozinho Malta, o som vocal grave colabora com a construção do personagem como o vilão da história.

Ao lado de Sinhozinho Malta, a Viúva Porcina também integra o núcleo dos vilões. No entanto, criando um contraponto com Sinhozinho Malta, a personagem possui uma voz predominantemente aguda. Em alguns momentos, Porcina modula a emissão vocal até produzir um timbre áspero e estridente. A voz passa a atuar como reforço para a personalidade forte da personagem, que resulta em ações desmedidas. Na primeira cena de Viúva Porcina na telenovela, por exemplo, a personagem reclama com o funcionário, Sr. Rodézio, por ele ter colocado patos ao invés de cisnes no lago da fazenda. Transtornada com a confusão do funcionário, Porcina o empurra dentro do lago e começa a gargalhar descontroladamente. O timbre áspero da risada realça a atitude perversa da personagem, associando a mesma à figura de uma bruxa. Durante a gargalhada há a inserção da canção Dona, interpretada pelo grupo Roupa Nova. Ouvimos os dois primeiros versos: "Dona desses traiçoeiros / Sonhos sempre verdadeiros". O estilo romântico da canção se contrapõe à agressividade de Porcina, salientando seu lado mais sensível, e a letra reforça a personalidade dominadora da personagem. Dessa forma, a canção articula características opostas e complementares de Porcina.

Outra forma de utilizar a voz para caracterizar os personagens ocorre através da utilização de bordões. No primeiro capítulo, por exemplo, parte da apresentação de Sinhozinho Malta acontece por meio de uma entrevista que o personagem concede a uma equipe de reportagem. Ao final da cena, Sinhozinho encerra a entrevista com a frase: "Tô certo ou tô errado?”. A entonação usada pelo personagem faz do questionamento uma pergunta retórica, que não tem como objetivo a obtenção de uma resposta. Ao longo do capítulo, o bordão é repetido para encerrar as falas de Sinhozinho Malta e reafirmar, autoritariamente, os posicionamentos do personagem.

Além das vozes, os ruídos também acentuam de forma caricata as características das personagens. Sinhozinho Malta é o caso mais emblemático da telenovela, marcado por um efeito sonoro de chocalho, que remete ao guizo de uma cobra. Retomando o exemplo anterior, 
no momento em que Sinhozinho Malta encerra a entrevista falando seu bordão, ouvimos o efeito sonoro do chocalho. O acento produzido pelo efeito sonoro associa Sinhozinho Malta à figura da cobra, reforçando de forma caricata o comportamento astuto e traiçoeiro demonstrado pelo personagem. Assim como o bordão, o efeito sonoro é retomado em diversos outros momentos da narrativa, reiterando por meio do som a maldade presente nas ações de Sinhozinho Malta.

Os ruídos também são utilizados para fazer transições de cenas e pontuar momentoschave da narrativa. No exemplo que citamos anteriormente - cena em que Sinhozinho Malta concede entrevista à equipe de reportagem - a ação se desenvolve em um único plano de imagem de Sinhozinho Malta sentado no banco de trás do automóvel. A equipe de reportagem não é visualizada. Dessa forma, a fala de Sinhozinho Malta é montada por meio de cortes do mesmo plano de imagem (jump cut). Esse tipo de montagem cria os chamados "saltos" de imagem, devido às elipses temporais longas que não promovem a sensação de continuidade. Na cena de Roque Santeiro, porém, a relação estabelecida entre som e imagem promove outra percepção. Em cada corte, o último quadro (frame) foi prolongado para durar aproximadamente 1 segundo, criando um breve congelamento de imagem. Nesses pontos foram inseridos ruídos de um obturador de câmera fotográfica e a impressão é que vemos Sinhozinho Malta através dos olhos do fotógrafo da equipe de reportagem, aos moldes de uma câmera subjetiva. Dessa forma, o fotógrafo passa a existir na cena a partir do ruído do obturador, ou seja, temos o que Chion denomina de personagem "acusmático", aquele que não é visualizado na imagem, mas se faz presente na narrativa por meio do som. (CHION, 2011)

Os ruídos também auxiliam a montagem da sequência em que o Prefeito de Asa Branca, Florindo Abelha, faz a mediação entre Gerson e Viúva Porcina, durante a troca de informações sobre o filme de Roque Santeiro. Essa sequência se desenvolve através do encadeamento de três cenas: primeiro, na praça de Asa Branca, Gerson pede ao Prefeito que o ajude a conseguir que Porcina abra mão da participação nos lucros do filme; em seguida, na casa de Porcina, o Prefeito repassa a solicitação a ela, que imediatamente não atende o pedido e exige ver o roteiro do filme antes que ele seja realizado; por fim, na Pousada do Sossego, o Prefeito dá a notícia a Gerson, que fica desestabilizado e diz que não permitirá que Porcina participe do roteiro.

A sequência se desenvolve em três espaços distintos: praça de Asa Branca, casa de Porcina e Pousada do Sossego. O encadeamento das cenas cria uma elipse temporal que subtrai da narrativa o percurso do Prefeito entre os três espaços. Assim, o tempo narrativo é 
acelerado com a presença instantânea do Prefeito nos três lugares subsequentes. Nesse caso, os efeitos sonoros fazem a transição das cenas, criando a ponte entre as trocas de espaço. Além disso, eles introduzem os diálogos, colaborando com a intenção e o ritmo das falas. $\mathrm{Na}$ primeira transição, da praça de Asa Branca para a casa da viúva Porcina, o efeito sonoro é criado a partir de instrumentos percussivos: bloco sonoro e pandeirola. O ritmo dos instrumentos acentua a reação inconformada de Porcina ao ouvir a solicitação feita pelo Prefeito. Já na transição seguinte, da casa de Viúva Porcina para a Pousada do Sossego, o efeito sonoro utilizado possui uma variação de frequência. A modulação cria uma cadência sonora decrescente, que colabora com o tom de humor da reação de Gerson ao ouvir as notícias trazidas pelo Prefeito.

No capítulo 100, os efeitos sonoros também são amplamente utilizados para criar acentos e sublinhados nos diálogos das personagens. Assim, eles guiam a leitura das falas destacando determinadas informações fornecidas pelas personagens. Com a repetição dessa estrutura ao longo da telenovela, os efeitos sonoros atuam como "ruído-sinal", termo utilizado por Florês para denominar esse tipo de som que "pode ser explorado como identificador de situações, faz reconhecer-se e torna-se significativo em uma segunda ocorrência". (FLÔRES, 2013, p. 132)

Em relação às músicas, Roque Santeiro foi a primeira telenovela da TV Globo, desde o padrão introduzido por Pecado Capital, a contar com canções exclusivamente nacionais. $\mathrm{O}$ produtor musical Mariozinho Rocha foi o responsável pela seleção das canções, priorizando temas populares interpretados por Dominguinhos, Zé Ramalho, Elba Ramalho, Fafá de Belém, Alceu Valença, entre outros. Sá e Guarabyra compuseram uma canção inspirada na história de Roque Santeiro, contando a trajetória do santo milagreiro. Luiz Carlos Sá explica como surgiu a ideia:

\footnotetext{
O Guarabyra trouxe uma forte contribuição folclórica ao nosso trabalho, então, nós já tínhamos feito um ABC chamado "Incelença", que a gente apresentava em show e fazia muito sucesso. Aí, quando o Mariozinho pediu a música, encontramos o Dias Gomes e sugerimos: "Por que não um ABC para o Roque Santeiro?". O Dias se empolgou e a gente fez. Primeiro o pessoal da Globo não queria, achava muito folclórico, muito regional. A gente insistiu, o Mariozinho também, acabou rolando e fez o maior sucesso. Naquela época, as pessoas tinham pouca noção do que era o interior do Brasil, então a música causou impacto pela sua característica regional. Além de ser também muito dramática, que casava tão bem com a proposta do Dias: misturar humor com drama. (BRYAN; VILLARI, 2014, p. 430-431)
}

A canção é usada logo no começo do primeiro capítulo para introduzir a história de Roque Santeiro e a cidade de Asa Branca. A cena sucede a colocação da estátua de Roque na 
praça em frente à igreja. Inicialmente, vemos a estátua de Roque e, em seguida, uma fusão de imagem faz a transição para o Cego Jeremias sentado nos degraus da igreja. Ele toca violão e canta a primeira estrofe da canção:

\author{
Dizem que Roque Santeiro, \\ Um homem debaixo de um santo, \\ Ficou defendendo o seu canto e morreu. \\ Mas sei que é ainda vivente, \\ Na lama do rio corrente, \\ $\mathrm{Na}$ terra onde ele nasceu.
}

Nesse trecho, a canção é usada de forma diegética ${ }^{31}$ e desempenha duas funções: introduz musicalmente a história de Roque Santeiro e apresenta Jeremias, o menestrel de Asa Branca que canta os acontecimentos da cidade e dos habitantes.

Após a primeira estrofe, há uma transição que alterna da versão cantada pelo Cego Jeremias para a canção original gravada por Sá e Guarabyra. A canção transita do espaço diegético para o não-diegético e, desse ponto em diante, os versos passam a apresentar Asa Branca. Enquanto vemos a rotina da cidade - as ruas movimentadas com os romeiros e as várias barracas que vendem lembranças de Roque Santeiro - ouvimos a última estrofe da canção:

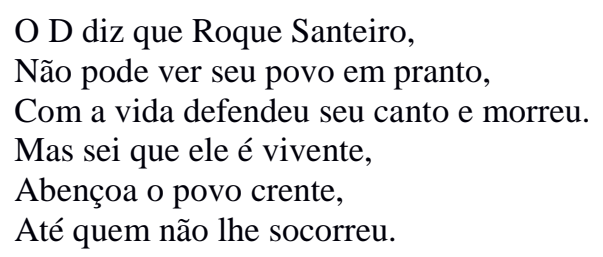

Enquanto a letra da canção ressalta o lado misericordioso de Roque Santeiro, vemos uma grande movimentação de dinheiro. São os fiéis que compram as mais variadas lembranças em torno da figura do santo. $\mathrm{O}$ contraponto criado entre a imagem e a canção passa a articular um dos temas centrais da telenovela: a exploração da fé.

Salvo as canções $A B C$ do Santeiro, Verdades e Mentiras e Santa fé (tema da abertura da telenovela), todas as outras canções da trilha musical são temas associados aos personagens. Dentre elas: o tema de Sinhozinho Malta, Isso aqui está muito bom, de Dominguinhos com a participação de Chico Buarque; o tema de Linda Bastos e Gerson, Sem pecado e sem juízo, composta por Baby Consuelo e Pepeu Gomes; o tema de Mocinha, Chora

\footnotetext{
${ }^{31}$ A música diegética é aquela que provem de uma fonte sonora presente no mundo da narrativa, ao contrário da música não-diegética que não pertence ao tempo e espaço indicado na imagem.
} 
coração, interpretada por Wando; o tema de Matilde, Indecente, de Anne Duá; e o tema de Porcina, Dona, citado anteriormente.

No primeiro capítulo de Roque Santeiro, observamos que os temas dos personagens são amplamente utilizados. Enquanto em Pecado Capital somente Lucinha é introduzida na telenovela ao som da sua canção tema, em Roque Santeiro, Sinhozinho Malta, Viúva Porcina, Matilde, Linda Bastos e Gerson, são todos apresentados por meio de seus temas. No caso de Sinhozinho Malta, por exemplo, enquanto o personagem sobrevoa sua fazenda em seu avião particular, ouvimos o refrão da sua canção tema: “Olha isso aqui tá muito bom, isso aqui tá bom demais / Olha quem tá fora quer entrar, mas quem tá dentro não sai”. Dialogando com as imagens, a letra da canção ressalta o estilo de vida de Sinhozinho Malta, que ostenta dinheiro e poder na cidade de Asa Branca.

A introdução de Matilde na história é a sequência mais longa, com 1 minuto de duração. A construção sonora da cena é realizada exclusivamente pelo tema da personagem, Indecente - não há vozes e ruídos. A relação som e imagem cria uma espécie de videoclipe para a apresentação da personagem na telenovela. Matilde e duas outras garotas saem da Pousada do Sossego e vão em direção à prefeitura para conversar com Florindo Abelha. Enquanto os planos de imagem mostram Matilde e as garotas percorrendo as ruas de Asa Branca de carro, ouvimos a letra cantada por Anne Duá:

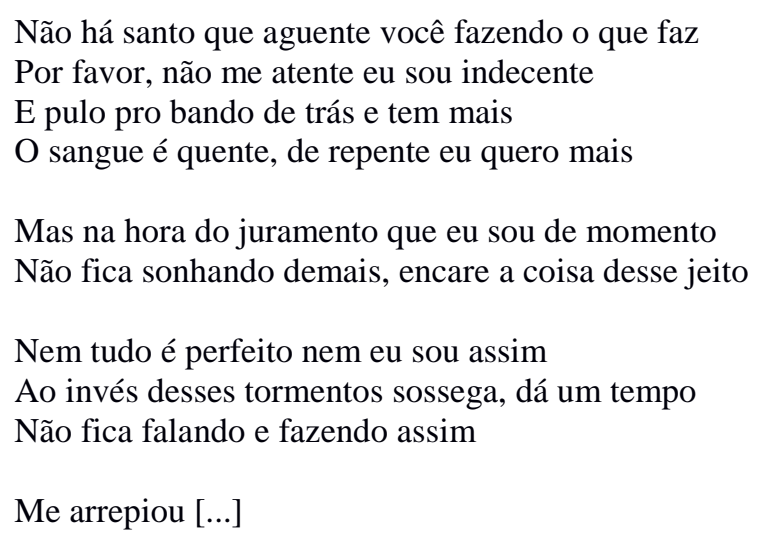

$\mathrm{Na}$ verdade, as duas garotas que acompanham Matilde são dançarinas recémcontratadas para trabalharem na boate de strip-tease, que está prestes a abrir na cidade. Assim, enquanto a canção fornece o ritmo e a continuidade espaço-temporal para a montagem das imagens, a letra intensifica o tom "provocante" das personagens, que "desfilam" pelas ruas de Asa Branca com roupas coloridas em cima de um automóvel vermelho e conversível. 
De acordo com Bryan e Villari, a relação entre as canções e as personagens foi tão significativa em Roque Santeiro que o sucesso da telenovela colocou as canções entre as mais ouvidas da época. Das 24 canções da trilha musical, "treze figuraram entre as cem mais ouvidas nas rádios em 1985 e o total de temas de novelas nessa listagem anual alcançou um número nunca antes visto ou repetido: 67 músicas, 31 delas nacionais”. (BRYAN, VILLARI, 2014, p. 414)

\title{
3.3. Renascer (1993)
}

\author{
Autoria: Benedito Ruy Barbosa \\ Direção-geral: Luiz Fernando Carvalho \\ Sonoplastia: Haroldo Barros \\ Produtor musical: André Sperling \\ Diretor musical: Mariozinho Rocha \\ Período de exibição: 08/03/1993 até 14/11/1993 \\ Horário: 20h30min \\ No de capítulos: 213
}

\subsubsection{Sinopse $\mathrm{e}^{32}$}

A novela é dividida em duas fases. Na primeira (os quatro capítulos iniciais), José Inocêncio (Leonardo Vieira) chega às roças de cacau de Ilhéus, na Bahia, e finca seu facão ao pé de um jequitibá, fazendo uma promessa: não morrer. A árvore passa a representar sua sorte, força e existência, acompanhando a trajetória do personagem ao longo de toda a narrativa. Enquanto o facão estiver fincado na terra, ele terá o corpo fechado e não morrerá, nem de "morte matada" nem de "morte morrida".

\footnotetext{
32 Retirada do website Memória Globo. MEMÓRIA GLOBO. Disponível em: <http://memoriaglobo.globo.com/programas/entretenimento/novelas/renascer/trama-principal.htm>. Acesso em: 05 mai. 2017.
} 
Com o passar dos anos, valente, trabalhador e obstinado, José Inocêncio constrói um verdadeiro império do cacau, e se casa com a doce e ingênua Maria Santa (Patrícia França), por quem devota um amor incondicional. Ela lhe dá quatro filhos, mas morre ao dar à luz João Pedro, rejeitado desde então pelo pai, que o culpa pela morte de seu grande amor.

Na segunda fase da novela, o coronel José Inocêncio (Antônio Fagundes) é um contador de histórias, que mantém uma aura mística ao seu redor. Um dos episódios que não cansa de contar é que seu amigo, o turco Rachid (Luiz Carlos Arutin), costurou sua pele com linha e agulha depois de ela ter sido arrancada por um bando de jagunços, assim que chegou à região. José Inocêncio é um homem reconhecido pelo senso de justiça, e querido pelos empregados, que lhe são inteiramente fiéis. Um exemplo é Deocleciano (Leonardo Brício na primeira fase e Roberto Bomfim na segunda), amigo e companheiro inseparável, casado com Morena (Regina Dourado): ambos trabalham e vivem na fazenda de cacau, e são adorados por João Pedro (Marcos Palmeira), de quem cuidaram desde criança. Outro, é a fiel Inácia (Chica Xavier), empregada da fazenda, que ajudou na criação dos meninos e tem grande devoção ao patrão. Inácia é uma mulher simples e sensível, que costuma ter visões e prever o destino das pessoas.

Os filhos José Augusto (Marco Ricca), José Bento (Tarcísio Filho) e José Venâncio (Taumaturgo Ferreira) moram e trabalham na cidade grande. Já o caçula João Pedro (Marcos Palmeira), que nunca deixou a fazenda, mantém-se ao lado do pai, mesmo sofrendo com sua indiferença. A desavença do fazendeiro com o filho mais novo rege diversas tramas paralelas da história. A relação dos dois piora com a chegada de Mariana (Adriana Esteves), por quem João Pedro se apaixona. Ele a leva para trabalhar na fazenda do pai sem saber que a jovem é neta de Belarmino (José Wilker), inimigo de José Inocêncio, morto na primeira fase da novela, e que sua intenção é se aproximar da família somente para se vingar. Ela não contava, entretanto, que se apaixonaria pelo coronel, a quem chama carinhosamente de "painho".

Depois de anos viúvo e sofrendo com a perda de Maria Santa, José Inocêncio se apaixona por Mariana e decide se casar com a moça, num duro golpe para João Pedro, que se vê obrigado a sufocar o amor que sente pela jovem. A notícia do casamento faz com que José Augusto, José Bento e José Venâncio exijam que o pai divida seus bens entre os filhos. Interessados na herança, os três, liderados por José Bento, acham que Mariana é uma aproveitadora, que está de olho apenas na fortuna do coronel. Eles chegam à fazenda do pai dispostos a enfrentá-lo e diversas tramas se desenrolam a partir daí.

O primogênito, José Augusto, escolheu a profissão de médico para agradar ao pai, mas não tem nenhuma vocação para a medicina. Solteiro, ele é simpático, porém mentiroso, e tem 
dificuldade em gerir a própria vida. José Bento é formado em direito, e é tão mimado quanto seus irmãos, acostumados desde pequenos a receber tudo "de mão beijada". Ele vive com Valquíria (Cláudia Lira) no Rio de Janeiro, mas os dois mantêm uma relação sem amor. O terceiro filho de José Inocêncio, José Venâncio, trabalha como engenheiro, mas também é sustentado pelo pai. No início da história, ele está casado com Eliana (Patrícia Pillar), com quem não é feliz. Fria e oportunista, Eliana não quer ter filhos - a principal desavença do casal - temendo que a gravidez estrague seu corpo. Desiludido com seu casamento, José Venâncio conhece a doce e feminina Buba (Maria Luisa Mendonça), que o leva a romper o relacionamento com Eliana. José Venâncio sabe que Buba é hermafrodita, só não tem coragem de revelar à família. O rapaz vai para a fazenda do pai na Bahia, mas acaba morto em uma tocaia preparada para atingir José Inocêncio. Posteriormente, Buba se envolve com José Augusto e, incentivada por ele, faz uma cirurgia e deixa de ser hermafrodita.

Outro personagem importante na trajetória de José Inocêncio é Teodoro (Herson Capri), vizinho de sua propriedade, o qual vive de olho em suas terras. Autoritário e maucaráter, Teodoro é casado com Yolanda (Eliane Giardini), a quem chama de Dona Patroa, uma mulher submissa que finge não saber das traições do marido. Os dois têm uma filha, Sandra (Luciana Braga). A certa altura, Yolanda dá uma reviravolta em sua vida e abandona Teodoro em busca de sua felicidade. Ele, por sua vez, casa-se com a interesseira Eliana (Patrícia Pillar). O inescrupuloso fazendeiro foi o responsável pela morte de José Venâncio, e é assassinado durante a trama. $\mathrm{O}$ crime levanta suspeitas sobre alguns personagens da novela, dentre eles, José Inocêncio, João Pedro (Marcos Palmeira) e o matador Damião (Jackson Antunes). Damião havia sido contratado por Teodoro para acabar com a vida de José Inocêncio, mas acaba virando empregado e fiel seguidor do homem que deveria matar. No fim, descobre-se que Teodoro foi morto por Mariana.

A mágoa de José Inocêncio com João Pedro só é superada no leito de morte, no capítulo final da trama. José Inocêncio, cansado e com a saúde debilitada, vai à cidade sozinho e sofre um acidente na volta para a fazenda. Com muita dificuldade, consegue voltar para casa, mas se recusa a receber medicação e agoniza. João Pedro, não querendo ver o pai sofrer, desenterra o facão para libertá-lo, ajudando-o a morrer. João retira o facão do pai dos pés do jequitibá e põe o seu no mesmo lugar, repetindo o gesto de José Inocêncio de anos atrás. João entrega o facão ao pai. José Inocêncio, então, pede um abraço ao filho como perdão por tantos anos de indiferença. A cena é uma das mais emocionantes da novela. Após a reconciliação, José Inocêncio morre e é recebido por Maria Santa. João Pedro consegue 
finalmente esquecer Mariana e termina a novela ao lado de Sandra, com quem tem uma filha. Mariana, sozinha, deixa a fazenda de cacau.

\subsubsection{Considerações sobre a trilha sonora}

Renascer foi a primeira telenovela "das oito" de Benedito Ruy Barbosa. Anteriormente, o autor escrevia para a faixa de horário das 18 horas, que tradicionalmente a TV Globo destina às histórias de época. A estreia de Benedito Ruy Barbosa no horário nobre da emissora teve relação direta com o sucesso obtido pelo autor com a telenovela Pantanal. Exibida pela TV Manchete em 1990, Pantanal foi responsável por criar uma concorrência direta com TV Globo, a qual se mantinha inabalável na liderança das telenovelas brasileiras desde a década de 1970. O êxito de Pantanal abriu caminhos para Benedito Ruy Barbosa levar para o horário nobre da TV Globo uma telenovela que tivesse a cultura popular como fio condutor. Assim, Renascer é inspirada no folclore, nas pessoas e nos costumes do sertão baiano.

No âmbito da trilha sonora, observamos que a música é uma das marcas do primeiro capítulo, fazendo-se presente em mais de $2 / 3$ da duração total do capítulo. Logo na primeira sequência da telenovela, as músicas predominam na narrativa, conduzindo a chegada de José Inocêncio em Ilhéus. A sequência começa com uma visão aérea de uma mata fechada. Ouvimos assobios de pássaros e uma música instrumental composta por viola, piano e cordas. A música sustenta a tensão da cena através da repetição cíclica de uma frase melódica de viola, que é acompanhada pela harmonia predominantemente dissonante do piano e das cordas. Uma fusão de imagens faz a transição da vista de cima da mata encoberta por neblina para o interior da floresta, onde vemos a silhueta de José Inocêncio. Nessa transição de cena há um efeito sonoro, remetendo à batida de um gongo, que chama a atenção para a aparição de José Inocêncio. Há também a inserção de outros ruídos ambientes, como o som da água corrente e mais assobios de pássaros. O aumento da presença dos ruídos ambientes conduz o movimento da narrativa de adentrar a mata. A partir desse ponto, há uma troca de músicas que introduz uma nova construção musical marcada por uma percussão de tambores. As batidas fornecem o ritmo para a montagem, que acelera os planos de imagem. Vemos José Inocêncio atravessando a vegetação e transpondo os cursos d'água. Enquanto o foley reforça cada 
movimento do personagem, os tambores criam uma cadência para a ação. A harmonia e a melodia mantém o clima de tensão da cena.

José Inocêncio se depara com um gigante jequitibá em meio à floresta. Novamente, o efeito sonoro que remete ao som de um gongo é utilizado para destacar uma informação importante da narrativa, dessa vez a figura do Jequitibá. A anunciação da árvore ganha um maior impacto com a introdução de uma terceira música. Os ataques dos acordes de piano e cordas são embalados por uma percussão de caixa e tímpano. O arranjo orquestral cria um tema épico para o encontro de José Inocêncio com o Jequitibá. Nesse ponto, a música desacelera o ritmo das imagens, promovendo a contemplação da gigante árvore. Ouvimos a voz de José Inocêncio, que após as primeiras palavras de admiração, grita o nome do Jequitibá. Nesse momento, a música cessa por completo e o grito de Inocêncio ecoa pela floresta. Com o encerramento da música, ouvimos somente os ruídos provenientes da natureza (pássaros, água, vento), gerando o que Gorbman denomina de "silêncio musical diegético", quando a ausência da música privilegia o som diegético e torna o "espaço diegético mais imediato, mais palpável"33. (GORBMAN, 1987, p. 18, tradução nossa)

O término da música cria uma transição para o início de um monólogo de José Inocêncio. Em seguida, capatazes adentram a mata e surpreendem o personagem, que é pendurado de ponta cabeça e torturado. Temos a retomada da segunda música e, novamente, as batidas dos tambores aceleram o ritmo das imagens. A montagem intercala planos rápidos da tortura de José Inocêncio, e o último plano é uma câmera subjetiva do personagem. Um dos capatazes joga um líquido no rosto de José Inocêncio e a imagem fica embaçada, o que cria uma fusão para a imagem da mata encoberta por neblina. A música cessa bruscamente e a sensação de silêncio marca novamente a transição de cena, criando um suspense em torno do destino de José Inocêncio.

$\mathrm{O}$ encerramento dessa longa sequência de aproximadamente 10 minutos acontece quando um viajante, Rachid, encontra José Inocêncio ainda vivo pendurado em uma árvore e o salva. Não detalharemos o desfecho, uma vez que as funções desempenhadas pelas músicas são semelhantes às que já foram descritas.

\footnotetext{
33 Gorbman descreve outros dois tipos de silêncio: o "silêncio não diegético" e o "o silêncio estrutural". O "silêncio não diegético" ocorre quando a trilha sonora está completamente sem som, quando não há conteúdo gravado na pista de áudio. O "silêncio estrutural" ocorre quando um som é previamente apresentado na narrativa e se faz ausente em outros momentos estruturalmente correspondentes. Nesse caso, somos encorajados a esperar um som apresentado anteriormente, mas quando não há, tomamos consciência de sua ausência. (GORBMAN, 1987, p. 18-9, tradução nossa)
} 
As músicas instrumentais também atuam como elementos de caracterização dos personagens. Por exemplo, na cena em que a procissão do Bumba Meu Boi se prepara em frente à casa de Venâncio, um grupo de pessoas dança e canta o tema folclórico do Bumba Meu Boi. No interior da casa de Venâncio, Maria Santa olha pela janela admirada com a roda de pessoas em volta do Bumba. No entanto, a personagem está proibida pelo pai de participar da brincadeira. Dessa forma, Maria Santa permanece dentro do quarto, dançando sozinha com uma boneca em mãos. Enquanto a personagem brinca com a boneca, a inserção do som de uma caixinha de música realça o lado infantil de Maria Santa. Assim, a música associa a personagem às características típicas de uma criança, tais como: inocência, pureza e ingenuidade.

A paixão de José Inocêncio por Maria Santa também é relavada com o auxílio de uma música instrumental. A cena começa com a procissão do Bumba Meu Boi chegando à fazenda de José Inocêncio. O grupo de pessoas canta o tema folclórico. Maria Santa está dançando em volta da roda e José Inocêncio se aproxima da brincadeira. A troca de olhares entre os personagens é acompanhada por um tema orquestral, marcado por uma melodia executada por um violino. A sobreposição do tema orquestral em relação à canção diegética do Bumba Meu Boi cria um desdobramento do tempo narrativo. A sensação é que o encontro entre Maria Santa e José Inocêncio acontece em um tempo particular e exclusivo aos dois personagens, regido pela melodia do violino. A atenuação da intensidade da canção do Bumba Meu Boi transporta para um segundo plano os acontecimentos em volta das personagens. Dessa forma, temos o que Gorbman classifica como "música meta-diegética", aquela que se refere ao que se passa no pensamento ou nas emoções de uma personagem. Nessa cena, o tema orquestral está tanto no nível não-digético, uma vez que não há fonte sonora indicada na imagem; quanto meta-diegético, pois acessa os sentimentos das personagens. (GORBMAN, 1987)

É válido ressaltar que a canção do Bumba Meu Boi dialoga diretamente com a proposta de Renascer em retratar a cultura popular brasileira. A partir do uso diegético da canção, a telenovela dá voz ao folclore brasileiro e o integra na narrativa. Isso também ocorre na última cena do capítulo, quando uma lavadeira canta uma canção para Maria Santa. Além de conduzir as imagens de Maria Santa tomando banho de rio, a voz da lavadeira transmite a identidade cultural daquele lugar.

Renascer segue a linha de Roque Santeiro com canções exclusivamente nacionais, dentre elas: o tema de Maria Santa, Lindeza, composto por Caetano Veloso; o tema de Dona Patroa, Dito e feito, interpretado por Roberto Carlos; o tema de Buba, Só pra te mostrar, de Daniela Mercury e participação de Herbet Vianna; o tema de Damião e Ritinha, Ai que 
saudade de ocê, interpretado por Fábio Jr; e o tema de Mariana, Mentira, de Adriana Calcanhoto.

No primeiro capítulo da telenovela a canção Lua Soberana, composta por Ivan Lins e Vitor Martins e interpretada por Sérgio Mendes, é utilizada na sequência que apresenta a fazenda de cacau de José Inocêncio. Salvo Lua soberana e as duas canções diegéticas citadas anteriormente - tema folclórico do Bumba Meu Boi e o canto da lavadeira - não há outras inserções de canções. Dessa forma, no primeiro capítulo de Renascer predominam as músicas instrumentais em detrimento dos temas cantados. Essa estrutura musical também se faz presente no capítulo 100, que contém 21 inserções musicais, sendo que desse total somente 5 são canções: Palavra acesa, interpretada por Quinteto Violado; Joaninha, interpretada por Itamara Koorax; Ai que saudade de ocê, interpretada por Fábio Jr.; Lua soberana, interpretada por Sérgio Mendes; e Dois corações, interpretada por Nana Caymmi. A canção Confins, interpretada pelo grupo Batacotô, utilizada na abertura e nas vinhetas do capítulo não foi considerada nesse cálculo.

No que diz respeito aos ruídos, como todas as cenas do primeiro capítulo acontecem em meio ao contexto rural, os ruídos ambientes são compostos principalmente por sons da natureza. Por exemplo, na cena em que José Inocêncio e Deocleciano nadam no rio e conversam sobre o Bumba Meu Boi - uma das cenas do primeiro capítulo que não há nenhum tipo inserção musical - a construção sonora do espaço ocorre por meio do som da água corrente e dos assobios de pássaros. Semelhante à cena em que Quitéria conversa com Venâncio sobre Maria Santa, o ambiente da casa da família é construído por meio de ruídos de grilos e mugidos de vacas.

Os sons da natureza também compõem os ambientes do capítulo 100. Como, por exemplo, na cena em que Noberto acorda de ressaca após a festa de casamento de Sandra e João Pedro. O personagem desperta com o cacarejar de um galo. O ruído cria sonoramente o movimento do amanhecer na cena, ampliando a narrativa para além dos limites do quadro da imagem. O cacarejar também colabora com a construção do ambiente rural que cerca a casa de Noberto. Essa sensação se intensifica com a inserção de assobios de pássaros. Há também, no capítulo 100, os ruídos de grilos e cigarras, que são utilizados principalmente na construção sonora dos espaços externos da narrativa.

No capítulo 1, o foley também transmite as sonoridades do campo, principalmente em torno das atividades do plantio de cacau. Na primeira cena de Belarmino no capítulo, por exemplo, enquanto um plano-sequência percorre o processo de estocagem do cacau até chegar ao cômodo onde o personagem se encontra, ouvimos o som proveniente da movimentação dos 
trabalhadores manipulando o cacau. A duração longa dos ásperos ruídos gerados pelo atrito das pás que raspam o chão reforça o caráter árduo e incessante das atividades executadas pelos trabalhadores do campo.

\subsection{Senhora do destino (2004)}

Autoria: Aguinaldo Silva

Direção-geral: Wolf Maya

Sonoplastia: Thanus Chalita e Haroldo de Sá

Produção musical: Edom Oliveira

Direção musical: Mariozinho Rocha

Período de exibição: 28/06/2004 até 12/03/2005

Horário: 20 horas

No de capítulos: 220

\subsubsection{Sinopse $^{34}$}

A trama de Senhora do Destino é dividida em duas fases. A primeira - exibida em quatro capítulos - se passa em dezembro de 1968, quando a nordestina Maria do Carmo Ferreira da Silva (Carolina Dieckmann), abandonada pelo marido Josivaldo (Manoel Candeias), parte com seus cinco filhos de Belém do São Francisco, no interior de Pernambuco, rumo ao Rio de Janeiro. Desesperada, ela escreve ao irmão, Sebastião (Luiz Carlos Vasconcelos), pedindo que ele os receba. Sebastião trabalha como motorista para Josefa Magalhães Duarte Pinto (Marília Gabriela), por quem é apaixonado. Ela é filha de família tradicional e dona do jornal carioca Diário de Notícias, herdado após a morte do segundo marido.

\footnotetext{
34 Retirada do website Memória Globo. MEMÓRIA GLOBO. Disponível em: <http://memoriaglobo.globo.com/programas/entretenimento/novelas/senhora-do-destino/trama-principal.htm>. Acesso em: 05 mai. 2017.
} 
Após uma série de contratempos na viagem, Maria do Carmo e os filhos chegam ao Rio de Janeiro no dia da decretação do Ato Institucional no 5 (AI-5), 13 de dezembro de 1968. Há um grande tumulto nas ruas do Centro, tomadas por manifestantes e policiais. O Diário de Notícias, opositor do regime militar, é invadido pela polícia, e Sebastião não consegue buscar Maria do Carmo na rodoviária. Como perdeu o papel onde havia anotado o endereço do irmão, ela segue com os filhos à procura do jornal, onde espera encontrar Sebastião. No meio da confusão em que se transformou a cidade, Reginaldo (Miguel Rômulo), um de seus filhos, é ferido por uma pedrada. Maria do Carmo consegue se refugiar com as crianças em uma casa abandonada. Nazaré (Adriana Esteves), após uma discussão com o amante Luís Carlos (Tarcísio Filho), também se abriga no local. Vestida como uma enfermeira e com uma falsa barriga de grávida, Nazaré diz se chamar Lourdes e promete tomar conta das crianças enquanto Maria do Carmo leva Reginaldo ao hospital. Na volta, porém, Maria do Carmo descobre que a mulher desapareceu com sua filha recém-nascida, Lindalva.

Nazaré, na realidade, é uma prostituta do bordel de Madame Berthe (Tônia Carrero) que deseja se casar com o amante e mudar de vida. Ela acredita que a gravidez é a única maneira de separá-lo da esposa e da filha. Como é estéril, inventou que estava grávida para forçar Luís Carlos a assumir a criança. Ao ficar sozinha com Lindalva em seus braços, Nazaré vislumbra a chance de concretizar seu plano e sequestra a menina. Após chantagear Madame Berthe para que confirme sua história, ela arma uma farsa e finge que deu à luz a criança, sensibilizando o amante, que larga a família para ficar com ela. A luta de Maria do Carmo para reencontrar a filha roubada é o fio condutor da novela.

Desolada com o sequestro de Lindalva, Maria do Carmo se perde nas ruas do Rio, é confundida com os manifestantes e levada presa, assim como Dirceu de Castro (Gabriel Braga Nunes), repórter do Diário de Notícias, que se recusa a abandonar a redação do jornal. Josefa também é presa, tem o jornal fechado e é aconselhada a deixar o país, o que a leva para um luxuoso exílio em Paris.

Maria do Carmo e Dirceu ficam em celas vizinhas no presídio da Ilha das Flores, e o jornalista toma conhecimento da história da nordestina. Dirceu chama a atenção do comandante da prisão para o equívoco, e a jovem é solta. Ela encontra Sebastião por acaso, e os dois conseguem impedir que as crianças, que haviam sido levadas para o Juizado de Menores, sejam enviadas para um orfanato. Maria do Carmo decide se instalar no mesmo lugar onde o irmão vive, em Vila São Miguel, na Baixada Fluminense, e jura que dedicará sua vida a localizar a filha Lindalva. 
Na segunda fase da novela, Maria do Carmo (Susana Vieira) é uma mulher forte e bem-sucedida, mãe dedicada de Reginaldo (Eduardo Moscovis), Leandro (Leonardo Vieira), Viriato (Marcello Antony) e Plínio (Dado Dolabella), e dona da loja de material de construções Do Carmo. É querida e respeitada em Vila São Miguel por sua ética e generosidade. Ela mantém um antigo relacionamento amoroso com Dirceu (José Mayer), agora editor e colunista político de um grande jornal carioca. Os dois moram em casas separadas e vivem uma relação tranquila. Mas a nordestina tem outro admirador: o exbicheiro Giovanni Improtta (José Wilker). Giovanni é presidente da escola de samba Unidos de Vila São Miguel. Uma de suas características é a inseparável gravata borboleta, além do esforço em falar de forma culta, que o leva a cometer vários erros de português. Seu modo de falar caiu nas graças do público, que reproduzia nas ruas expressões como "felomenal" (em vez de “fenomenal”). Giovanni é pai de João Manoel (Heitor Martinez) e Jennifer (Bárbara Borges). Viúvo, mora com os filhos e a sogra, Flaviana (Yoná Magalhães). Tem como namorada a aspirante a celebridade Danielle (Ludmila Dayer), a quem chama de "Ninfa Bebê". Mas o ex-bicheiro, que vive repetindo não dever nada à polícia nem ao fisco, é apaixonado mesmo por Maria do Carmo, tendo que disputar o seu amor com o rival Dirceu, a quem se refere como "Troca Letras".

Sebastião (Nelson Xavier), o irmão de Maria do Carmo, casou-se com Janice (Mara Manzan) e tem três filhos: Eleonora (Mylla Christie), Venâncio (André Gonçalves) e Regininha (Maria Maya). É motorista do refinado Pedro Correia de Andrade e Couto (Raul Cortez), o barão de Bonsucesso, e de sua esposa, a baronesa Laura (Glória Menezes). Ao longo da história, Regininha engravida do namorado João Manoel, e, no fim da trama, os dois apressam o casamento. Danielle e Venâncio, casados, descobrem que vão ser pais.

Lindalva, a caçula roubada de Maria do Carmo e batizada como Isabel (Carolina Dieckmann), transformou-se em uma jovem doce e bonita, que tem uma relação de cumplicidade com a perturbada e perigosa Nazaré (Renata Sorrah), que ela pensa ser sua mãe. Nazaré ainda vive com Luís Carlos (Tarcísio Meira) e está sempre em guerra com a enteada Cláudia (Leandra Leal), que foi morar com o pai após sua mãe, abandonada pelo marido, sucumbir à depressão e morrer.

A farsa de Nazaré começa a vir à tona quando o fotógrafo Rodolfo (Reinaldo Gonzaga) entrega a Dirceu a foto de uma enfermeira grávida com um bebê no colo, tirada por ele durante o tumulto no centro do Rio, em dezembro de 1968. Maria do Carmo e Leandro reconhecem a sequestradora. Dirceu pede a Rodolfo que use programas de computador para "envelhecer" a foto e chegar ao rosto atual da mulher. Depois, consegue que a história de 
Maria do Carmo seja tema de um programa investigativo na TV. Luís Carlos assiste ao programa e diz à Nazaré que vai denunciá-la. Os dois discutem, e ele cai da escada de casa. No chão, com fortes dores no peito, pede à Nazaré que pegue o seu remédio, mas ela não o socorre.

Com a morte do pai, Isabel começa a trabalhar no restaurante Monsieur Vatel, de propriedade de Edgard (Dan Stulbach). Os dois se apaixonam. O maître Viriato (Marcello Antony) nem imagina que a namorada do patrão é sua irmã desaparecida. O namoro de Isabel e Edgard deixa Nazaré desesperada, pois o rapaz é neto de Madame Berthe. No final da trama, o receio de Nazaré se justifica: é o diário da cafetina que confirma a história do sequestro. Antes disso, a vilã "apronta" bastante ao longo da trama. Ela passa a ter como amante e aliado o inescrupuloso Josivaldo (José de Abreu), o marido desaparecido de Maria do Carmo que volta para a família pedindo pensão alimentícia à mulher.

Enquanto Maria do Carmo continua a busca pela filha, Dirceu e Giovanni tentam a todo custo localizar a menina. Em uma dessas tentativas, aparece Angélica (Carol Castro), que foi encontrada ainda bebê no mesmo dia do desaparecimento de Lindalva. Mas a alegria de Maria do Carmo dura pouco: Angélica tem uma pinta de nascença na perna e, portanto, não pode ser a filha sequestrada. Mesmo assim, Maria do Carmo a acolhe em casa e faz dela sua secretária na loja. Angélica se envolve com Plínio.

O cerco contra Nazaré vai se fechando, com a colaboração de vários amigos de Maria do Carmo, inclusive Cláudia, a enteada da vilã. Ela também se torna aliada da nordestina, pois sempre odiou a madrasta.

Mesmo após descobrir que foi roubada de sua mãe verdadeira, Isabel ainda leva um tempo até aceitar Maria do Carmo como mãe. Nazaré pede desculpas à jovem, diz que agiu em um momento de desespero. Dividida e sensibilizada, Isabel decide ficar a seu lado, até se dar conta de seu verdadeiro caráter.

Uma das surpresas preparadas pelo autor foi a volta à trama da atriz Marília Gabriela. Ela retorna à novela no papel de Guilhermina, a filha de Josefa, que se torna um obstáculo na realização de um antigo sonho de Sebastião e Dirceu: reabrir o Diário de Notícias. Guilhermina tenta impedir o leilão de um original do pintor Cézanne, que Josefa havia deixado para Sebastião, e cuja renda seria usada para a reabertura do jornal. A tela permaneceu vários anos escondida no Galaxie, que Sebastião herdou de sua ex-patroa e mantém guardado em sua garagem. Apesar dos entraves, o jornal é reaberto, e nele passam a trabalhar Cláudia, Alberto e Rodolfo. Guilhermina e Dirceu se estranham em um primeiro momento, e seus encontros sempre terminam em troca de acusações. A hostilidade mútua dá 
lugar à paixão, e os dois ficam juntos no fim da história, depois que Maria do Carmo aceita se casar com Giovanni. A torcida do público pelo ex-bicheiro era grande, e o autor só mostrou esse desfecho no último capítulo, para manter o suspense.

Nazaré morre, após se atirar de uma ponte na cachoeira de Paulo Afonso, na Bahia. Ela se suicida após sequestrar Linda, a filha de Isabel e Edgard. Diante de Isabel, porém, ela se redime e lhe entrega o bebê antes de saltar para a morte. Josivaldo acaba nas ruas, como um mendigo maltrapilho e enlouquecido.

\subsubsection{Considerações sobre a trilha sonora}

Em Senhora do Destino, Aguinaldo Silva abriu mão do realismo fantástico - uma das marcas das telenovelas anteriores do autor - para criar uma história que dialogasse com a realidade. O drama vivido por Maria do Carmo, que tem sua filha recém-nascida sequestrada por Nazaré, foi inspirado no caso real de Pedrinho. O menino foi sequestrado na maternidade por Vilma Martins Costa, em 1986. A sequestradora foi descoberta somente em 2002, quando Pedrinho já estava com 16 anos de idade. Vilma também havia sequestrado outra criança em Goiânia e foi condenada a 13 anos de reclusão pelos dois crimes. (MEMÓRIA GLOBO, 2013)

Além de reviver o caso de Pedrinho, Aguinaldo Silva também utilizou referências autobiográficas para desenvolver outras temáticas em Senhora do Destino, tais como: a migração, o pano de fundo da história de Maria do Carmo, que remonta o percurso de Aguinaldo Silva que migrou da região nordeste para o sudeste do país; a ditadura militar, abordada nos primeiros capítulos, reconstituindo os tempos que o autor ficou preso em Ilha das Flores por ter escrito o prefácio dos Diários de Che Guevara; o jornalismo, ofício anterior de Aguinaldo Silva, que na telenovela é desenvolvido através do jornal Diário de Notícias e do jornalista Dirceu, um dos personagens centrais da história; e a homossexualidade, orientação sexual do autor, que foi abordada na telenovela por meio do casal de lésbicas Jennifer e Eleonora.

O primeiro capítulo da telenovela começa em Pernambuco. Maria do Carmo e seus filhos estão em uma feira ao ar livre, nos arredores de Belém do São Francisco. Inicialmente, vemos um gavião sobrevoando o local e ouvimos o som proveniente do crocitar da ave. $\mathrm{O}$ ruído agudo e estridente acompanha a trajetória do gavião até o pouso da ave em um telhado. 
Em seguida, um plano-sequência introduz o ambiente da feira. Vemos carroças e bicicletas transitando pelo local, algumas pessoas andando com cestas nas mãos e outras carregando animais e palha nos ombros. Ouvimos as vozes em off ${ }^{35}$ dos feirantes, que anunciam suas mercadorias aos compradores. Há também os berros de cabras e bodes que estão à venda na feira. Os ruídos ambientes ampliam o espaço para além dos limites do quadro da imagem, transmitindo a regionalidade do sertão nordestino, principalmente por meio dos sons dos animais típicos do local: gavião, bodes e cabras. Além disso, os ruídos promovem a sensação da movimentação e aglomeração no entorno da feira. No alto de uma edificação, o gavião observa o vai e vem das pessoas e, novamente, ouvimos o crocitar da ave. O ruído cria a transição sonora para uma música diegética, que é executada por um grupo de músicos que caminha pela rua. Eles tocam uma versão instrumental de Asa Branca. Enquanto a melodia é executada pelo sanfoneiro, os outros três músicos fazem a percussão com bandeiro, triângulo e zabumba. A partir desse ponto, a música passa a conduzir os planos de imagem das várias bancas e barracas dispostas ao longo da feira.

Após essa apresentação do espaço da feira, vemos Maria do Carmo acompanhada dos cinco filhos. Enquanto ela observa alguns itens dispostos em uma das bancas, Reginaldo, um de seus filhos, se distancia da família. O garoto caminha sozinho pela feira e uma banca de doces lhe chama a atenção. Nesse instante, a inserção de uma música instrumental marca os olhares de Reginaldo em direção aos doces. Paralelamente, vemos a imagem do gavião no alto da edificação. A ave passa a observar as ações de Reginaldo, que corre em direção à banca de doces e olha de perto uma cesta cheia de broas. Os acordes dissonantes sustentam o suspense em torno da ação do garoto. Ele está prestes a furtar uma das broas e sua intenção é anunciada pelo crocitar do gavião. Reginaldo rouba uma broa e a coloca no bolso. O aumento da quantidade dos ruídos emanados pelo gavião gera um tom de violência, que acentua a ação transgressora realizada pelo personagem.

Maria do Carmo observava Reginaldo de longe e, ao perceber que o garoto furtou a broa, aproxima-se e o obriga a devolvê-la. No momento em que Reginaldo coloca a broa de volta na cesta, o gavião fica em silêncio e voa para longe. A presença e a ausência do gavião na cena polariza o comportamento de Reginaldo. A ave acompanha a ação do personagem durante a prática do furto. O ruído emitido por ela cria um símbolo sonoro para o desvio de

\footnotetext{
${ }^{35}$ De acordo com a definição proposta por Bordwell e Thompson, o som onscreen é aquele que se origina de uma fonte sonora visível no quadro da imagem, ou seja, quando ouvimos uma pessoa falando vemos a pessoa falando. Por outro lado, o som offscreen provem de uma fonte sonora que também pertence ao mundo da narrativa, mas não está visível no quadro da imagem. (BORDWELL; THOMPSON, 1986, p. 367)
} 
conduta do garoto. Quando Maria do Carmo obriga Reginaldo a devolver a broa roubada, o silenciar da ave marca o momento em que a atitude do garoto é corrigida pela honestidade da mãe.

Ao longo do primeiro capítulo, observamos que há uma associação direta entre o gavião e Reginaldo. A presença da ave em algumas cenas ressalta momentos-chave do personagem na história. Por exemplo, na cena em que Maria do Carmo se prepara para partir de Belém do São Francisco. Ela pede a Reginaldo que ele leve Baleia, a cachorra da família, para a casa de dona Bil. O garoto insiste para que Baleia vá com eles na viagem, mas Maria do Carmo diz que não será possível levá-la no ônibus. Reginaldo vai embora decepcionado e Baleia corre na direção dele. Os irmãos de Reginaldo perseguem a cachorra na tentativa de prendê-la. A inserção de uma música instrumental reforça a tristeza de Reginaldo diante da separação da cachorra. O caminhar lento de Reginaldo em meio aos terrenos áridos do agreste pernambucano é conduzido pela melodia executada por uma rabeca. $\mathrm{O}$ instrumento típico da música nordestina também atua na composição do espaço da cena, transmitindo dados culturais daquela localidade.

Em seguida, os quatro irmãos chegam a um cemitério. Reginaldo fica para trás e os três irmãos continuam perseguindo Baleia. Próximo a Reginaldo, vemos um gavião pousado em um galho de árvore e o ruído emitido pela ave predomina em meio ao ambiente desértico. O gavião voa em direção a um lagarto que está em uma pedra e Reginaldo corre na mesma direção. O lagarto é capturado e levado para o galho de uma árvore, onde é morto e comido pela ave. Reginaldo observa tudo de perto e, após presenciar a ação predatória do gavião, segue caminhando.

A partir desse ponto, o ruído emitido pela ave passa a acompanhar o percurso de Reginaldo. Ao ver os irmãos voltando com Baleia presa em uma coleira, Reginaldo diz que preferia que a cachorra estivesse morta. Inicialmente, o personagem estava triste por ter que se separar da cachorra e a música reforçava esse sentimento. Com o surgimento do gavião na cena, os ruídos da ave assumem o primeiro plano sonoro, conduzindo a transferência do comportamento predatório da ave de rapina - que há poucos instantes matou a presa a sangue frio - para Reginaldo, que passa a desejar a morte de Baleia. Assim, o som cria um símbolo para a mudança de comportamento do personagem.

Mais adiante no capítulo - após a partida de Maria do Carmo e os filhos de Belém do São Francisco - Baleia foge novamente e tenta alcançá-los. A família viaja na carroceria de um caminhão, a cachorra se aproxima, mas é atropelada por outro automóvel que vinha na direção contrária. Maria do Carmo e os filhos descem do caminhão e vão em direção à Baleia. 
Mas a cachorra não resiste e agoniza até morrer. Diversos gaviões voam ao redor da família e a grande quantidade de ruídos emitidos pelas aves cria o tema para a morte da cachorra. Os ruídos das aves também promovem a conexão com o momento em que Reginaldo desejou a morte de Baleia, retomando a ruptura na afetividade do personagem. Essa transformação é significativa para Reginaldo, que mais adiante na história se transforma em um dos vilões da telenovela.

Os ruídos também desempenham um importante papel na cena em que as manifestações tomam conta das ruas do Rio de Janeiro. A sequência começa no momento em que Flávio entra na sala de Josefa para informá-la que a situação política do Brasil está crítica. O Ministro da Justiça está prestes a decretar um ato para intervir no país, o Ato Institucional $\mathrm{n}^{\circ}$ 5. Durante o diálogo dos personagens, ouvimos o ruído off de uma sirene de polícia. O som agudo e contínuo da sirene cria a tensão da cena e amplia o espaço da imagem, anunciando as manifestações que estão ocorrendo do lado de fora do jornal.

$\mathrm{Na}$ cena subsequente, os protestos tomam conta das ruas e os manifestantes carregam faixas e gritam: "O povo unido jamais será vencido!". Um homem faz um discurso no megafone em prol da justiça social. Durante a fala do personagem, uma construção gráfica composta por recortes de jornais o apresenta como Vladimir Palmeira ${ }^{36}$. A voz do personagem e os ruídos ambientes continuam articulando a narrativa das manifestações nas ruas do Rio de Janeiro, enquanto a imagem faz um deslocamento do espaço-tempo diegético para fornecer as informações sobre Vladimir Palmeira. Nesse trecho, a inserção de ruídos de máquina de escrever preserva a relação entre som e imagem. As batidas da máquina de escrever acompanham o movimento das páginas de jornal e pontuam o aparecimento das letras que formam o nome Vladimir Palmeira.

Após a apresentação do personagem, a narrativa se concentra novamente nos protestos em frente à sede do jornal. A polícia chega ao local. Além do discurso de Vladimir Palmeira e os gritos dos manifestantes, há a inserção de uma música instrumental. A percussão de caixa e tímpano cria um tema marcial para a presença dos militares. Dirceu se aproxima dos policias e questiona de quem é a ordem para reprimir o protesto, mas é empurrado por um deles. Os militares marcham em direção aos manifestantes. A pulsação gerada pelo ruído dos passos cadencia o avanço da tropa. Os dois grupos se encontram e os ruídos provenientes do atrito dos escudos e cacetes marcam sonoramente o início do confronto.

\footnotetext{
${ }^{36}$ Vladimir Palmeira foi membro do movimento estudantil e liderou diversas manifestações contra a ditadura militar.
} 
Paralelamente, vemos Sebastião, o motorista de Josefa, caminhando em direção a uma loja. Ele adentra o local para retirar o vestido da patroa, mas é obrigado a sair às pressas devido aos ataques dos manifestantes. O confronto nas ruas se intensifica e a montagem acelera com o aumento da quantidade dos planos de imagens. As transições rápidas são acentuadas pela inserção de mais ruídos ambientes: sirenes, latidos dos cães policiais, bomba de gás lacrimogêneo, entre outros. Em meio à situação caótica, Sebastião caminha em direção ao seu veículo, mas é interceptado por dois agentes do DOPS.

A partir desse momento, há uma troca de músicas. O tema marcial, que regia o movimento da tropa, é substituído por uma música com a predominância de baixas frequências. A harmonia grave e dissonante executada pelo piano e cordas aumenta ainda mais a tensão da cena. Os agentes abordam Sebastião e o interrogam. Um deles perde o controle e coloca uma arma na boca de Sebastião. A ameaça de morte imposta pelo agente é intercalada com as imagens do confronto nas ruas. À medida que os militares reprimem os manifestantes, a expectativa em torno do destino de Sebastião aumenta. O clima de suspense é interrompido pelo "clique" do revólver do agente que não realiza o disparo. Diante da falha ocorrida na arma, o agente desiste e vai embora. Sebastião, por sua vez, volta ao jornal carregando o vestido de Josefa. Ao entrar na redação, o personagem lembra imediatamente do ocorrido, mas em suas lembranças o disparo da arma de fogo acontece. O ruído do tiro é um som interno que transmite um dado psicológico do personagem, ou seja, ele ainda está tomado pelo medo devido à situação de perigo vivida momentos antes.

É válido ressaltar que na transição da cena externa da rua para o interior da sede do jornal, o som orienta a troca dos espaços. Quando os agentes do DOPS vão embora, Sebastião permanece imóvel, encostado no veículo. Ouvimos os ruídos provenientes dos conflitos espalhados pelas ruas e a música que sustenta a tensão da cena. Quando há o corte seco para o interior da sede do jornal, o primeiro plano de imagem é uma porta abrindo. O ruído proveniente do movimento da fechadura cria o ponto de transição entre os espaços. A intensidade e a tensão sonora, que construíam a cena do conflito, são substituídas pelos ruídos ambientes da redação do jornal, compostos basicamente pelas vozes das pessoas que conversam no local. Essa transição sonora altera a leitura da cena, desacelerando o ritmo narrativo.

A mesma construção sonora ocorre na transição entre a cena na casa de Josefa para a cena subsequente em Belém do São Francisco. No interior da casa, Josefa fala ao telefone e a ausência de outros elementos sonoros promove a sensação de ambiente silencioso. A transição para a cena seguinte acontece no momento em que Josefa coloca o telefone no gancho, 
criando o ponto de corte para a imagem do cajado de Matusalém, tocando o chão em Belém do São Francisco. O ruído do telefone sendo colocado no gancho culmina no som breve e grave do cajado atingindo o chão. Então, o espaço silencioso da casa de Josefa é contraposto com os ruídos ambientes provenientes da paisagem natural de Belém do São Francisco. Ouvimos o movimento das águas do rio, os pássaros cantando e o vento tocando a vegetação. Além disso, a inserção de uma versão instrumental da canção Encontros e despedidas retoma o contexto da partida de Maria do Carmo e os filhos. O tema já havia sido apresentado anteriormente, na cena em que Maria do Carmo lê a carta em que Sebastião afirma que irá recebê-la no Rio de Janeiro.

Em Senhora do destino, observamos que as músicas também orientam a mudanças dos espaços, e são elementos importantes para a condução da narrativa. No início do capítulo, por exemplo, após a apresentação de Maria do Carmo e os filhos, a história se desloca para a cidade do Rio de Janeiro. A transição entre os diferentes espaços geográficos acontece através da inserção de um tema de bossa nova. O estilo musical tipicamente carioca contextualiza as imagens da cidade. A partir desse ponto, a narrativa passa a desenvolver o personagem Dirceu.

A sequência começa com Dirceu andando de bicicleta em meio à paisagem montanhosa. Enquanto a música conduz os diferentes planos de imagem do personagem, os ruídos provenientes do movimento da bicicleta reforçam o seu deslocamento. Uma mudança repentina de música altera abruptamente a leitura da cena. Mantendo o estilo bossa nova, a segunda música apresenta uma harmonia marcada por acordes dissonantes, que anunciam que algo está prestes a acontecer. Descobrimos que Dirceu está sendo seguido por agentes do DOPS (Departamento de Ordem Política e Social) e a tensão criada pela música passa a conduzir a fuga do personagem. Na tentativa de despistar os agentes Dirceu para em uma bica d'água e os agentes passam por ele. A utilização de ataques rápidos de instrumentos musicais revela o estado psicológico de Dirceu, que está assustado com a perseguição. Com a saída dos agentes de cena, há uma nova troca de música, que faz a transição para uma construção gráfica criada a partir de fotos. Essa terceira música também preserva as características do estilo bossa nova, mas repousa a tensão da música anterior com a predominância de acordes consonantes executados em um andamento mais lento. As fotos apresentam o personagem Dirceu e mostram o seu envelhecimento até a idade que ele assumirá na segunda fase da telenovela.

Após o flashfoward, voltamos ao ano de 1968. A música permanece na cena ligando os dois pontos da narrativa. Dirceu sai de casa e entra em um bonde. Ao embarcar, o 
personagem olha para fora do vagão e visualiza a viatura da polícia. Novamente, há a inserção dos ataques rápidos de instrumentos musicais, que retomam o sentimento de Dirceu em relação aos militares. Dirceu segue viagem e não vemos mais a viatura da polícia. O bonde percorre o Arco da Lapa e, a partir desse ponto, temos a inserção de uma quarta música. $\mathrm{O}$ estilo bossa nova é mantido, mas a música apresenta uma nova melodia executada por um saxofone. O andamento lento, marcado pelos acordes de piano e pelo ritmo da bateria, preserva o repouso iniciado pela música anterior. Voltamos ao interior do bonde, Dirceu lê a manchete no jornal Diário de Notícias sobre a chegada da rainha Elizabeth II ao Rio de Janeiro. Um corte seco faz a transição da imagem da capa do jornal para Dirceu caminhando por uma rua da cidade. Nesse trecho, há uma longa elipse temporal que suprime parte do deslocamento de Dirceu, mas a permanência da música unifica a montagem e fornece a continuidade para a ação do personagem. Dirceu caminha por uma rua, Sebastião passa de carro ao seu lado e vemos Josefa no banco de trás do automóvel.

Desse ponto em diante, o foco narrativo passa a ser Josefa e a música começa a articular as ações da personagem. Josefa passa de carro por Dirceu e chega à sede do jornal Diário de Notícias. A melodia lenta e suave, executada por um saxofone, acompanha o movimento de Josefa, que entra na sede do jornal. Os ruídos constroem o ambiente movimentado do jornal: vozerio, telefone, máquina de escrever, manuseio de papéis e ventiladores. Dirceu também entra na sede do jornal. A música diminui de intensidade até cessar por completo, criando a transição para o início do diálogo. Por meio das falas de Josefa, descobrimos que ela é a proprietária do Diário de Notícias e Dirceu é um jornalista associado. A conversa também informa o contexto da repressão dos militares e explica a perseguição vivida por Dirceu momentos antes. Da aparição de Dirceu na narrativa até aqui, temos uma longa sequência de aproximadamente 3 minutos e, em 2/3 desse tempo, a música é o elemento central da trilha sonora.

Ao longo do capítulo, a repetição da quarta música da sequência anterior caracterizada pelo som do saxofone - cria um tema para a presença de Josefa na narrativa. A primeira repetição acontece na cena em que Josefa está sozinha em uma sala, na sede do jornal. Ela prova joias para a cerimônia de recepção da rainha Elizabeth II. A melodia do saxofone, executada em um andamento lento, cria um tom romântico para a cena. As imagens de Josefa experimentando os colares em frente ao espelho revelam um aspecto mais sensível de sua personalidade, contrapondo-se ao comportamento incisivo da personagem diante dos funcionários. Quando Flávio entra na sala, a revelação do íntimo da personagem é interrompida. A música cessa e temos a passagem para o início de um diálogo. Mais adiante 
no capítulo, a mesma versão do tema é utilizada durante a cena em que Sebastião aguarda Josefa no interior do veículo. O vestido de Josefa está sobre o banco do passageiro e Sebastião se aproxima dele. No momento em que Sebastião toca o vestido, a inserção da melodia do saxofone retoma a figura de Josefa na cena. A presença da personagem por meio da música revela a paixão de Sebastião por ela.

A última utilização do tema ocorre ao final da sequência da recepção da rainha Elizabeth II. A sequência começa do lado de fora da cerimônia. O carro de Josefa se aproxima e ela desembarca no tapete vermelho. Ouvimos uma música orquestral de fundo e ruídos de máquinas fotográficas. No caminho até a entrada, Josefa olha para trás e vê o General Arthur Costa e Silva. No interior do salão, a música orquestral continua e Josefa dialoga com os outros convidados. Uma troca de música dá inicio a uma sinfonia marcada pelas vozes de um coral. A potência do canto anuncia a chegada da rainha e gera um impacto para a sua entrada no salão. Elizabeth II percorre o longo corredor formado pelos convidados, a música diminui de intensidade e temos o início de um diálogo entre a rainha e Josefa.

Do lado de fora, Dirceu conversa com Sebastião e a presença do som atenuado da música em off mantém a relação com o espaço-tempo da cerimônia. Após o diálogo entre os dois personagens, voltamos ao interior do salão, onde Josefa conversa com o General Bandeira. A sequência termina com Josefa saindo da cerimônia. Do lado de fora, os fogos de artifício encerram a homenagem à rainha Elizabeth II. Sebastião recebe Josefa em frente ao carro e os dois vão embora. Nesse instante, temos a inserção do tema de Josefa, que faz a transição da sequência da cerimônia para a cena no interior da casa da personagem. Dessa vez, o tema da personagem apresenta uma variação de arranjo, sendo executado por instrumentos orquestrais. Assim a transferência do foco narrativo para Josefa acontece em consonância com o estilo musical utilizado ao longo de toda a cerimônia da Rainha Elizabeth II.

As variações de arranjo também acontecem no âmbito das canções da trilha musical. Cordeiro de Nanã, interpretada por Thalma de Freitas, é o tema de Maria do Carmo e os filhos. Ao longo do primeiro capítulo a canção é inserida uma vez na versão original e outras quatro vezes com variações de arranjo. A inserção da primeira variação ocorre logo no início do capítulo, quando Maria do Carmo e os filhos retornam de barco à Belém do São Francisco. O tema é composto por voz, violão e violino. Apesar da presença do canto, a voz não articula palavras, atuando na canção aos moldes de um instrumento melódico. Nesse primeiro momento, o arranjo cria uma introdução para o desenvolvimento do tema e para o núcleo narrativo de Maria do Carmo. 
A segunda aparição de Maria do Carmo na narrativa ocorre às margens de um rio, quando a personagem lava roupa em cima de uma pedra. Nessa cena, a canção é executada na versão original, que começa apenas com a melodia do canto. O ruído proveniente da movimentação das águas do rio acompanha a voz de Thalma de Freitas. A suavidade criada a partir da junção dos dois elementos sonoros contribui com o clima contemplativo da paisagem natural. Maria do Carmo observa os filhos brincando e nadando no rio, e a canção ganha corpo com a inserção da harmonia de piano. Ao final da cena, Maria do Carmo segue em direção à casa de Dona Bil. O canto cessa e cria a passagem para o início do diálogo. Os acordes de piano permanecem durante a fala das personagens. A mudança do arranjo da canção ocorre de acordo com as ações da imagem e estabelece um equilíbrio entre os elementos da trilha sonora. Durante a melodia do canto, os ruídos ambientes são valorizados e integrados harmonicamente à canção. Quando o canto encerra, as vozes das personagens assumem a centralidade da trilha sonora e a harmonia do piano passa a acompanhar o diálogo.

Uma segunda variação da canção é apresentada na cena em que Maria do Carmo cuida de Lindalva. A reiteração do tema de Cordeiro de Nanã retoma o contexto narrativo de Maria do Carmo. Ao invés do canto, a melodia da canção é executada por uma sanfona. Por ser um instrumento tipicamente utilizado na música nordestina, o som da sanfona passa a também compor o espaço da cena.

A terceira variação da canção se faz presente no momento em que Maria do Carmo e os filhos estão de partida para o Rio de Janeiro. Após a morte da cachorra Baleia, a família segue a pé pelo sertão. Cansados da caminhada, Maria do Carmo e os filhos param para descansar e acabam avistando a estrada ao longe. A inserção do tema de Cordeiro de Nanã enfatiza a euforia da família e a esperança de chegar ao Rio de Janeiro. A melodia do violino e flauta é acompanhada por um violão e banjo. A execução da música em um andamento mais rápido colabora com clima alegre da cena. Maria do Carmo e os filhos esperam conseguir uma carona.

Ao final do capítulo, a família já está no ônibus a caminho do Rio de Janeiro. Maria do Carmo dialoga com outra passageira a respeito da sua viagem, conta sua história de vida e fala da expectativa de chegar ao Rio de Janeiro. A passageira diz para ela não se preocupar e afirma que vai dar tudo certo. Após o diálogo, temos a quarta variação da canção, a última inserção do tema no capítulo. Nesse trecho, a melodia é executada por uma flauta, que é acompanhada por um violão. A quantidade menor de instrumentos e o andamento mais lento geram um repouso para cena. A expectativa criada no momento em que Maria do Carmo 
tentava uma carona é concluída com a imagem do ônibus seguindo viagem por uma longa estrada.

A utilização de variações instrumentais dos temas das canções é uma das marcas do capítulo 1 de Senhora do Destino. Essa característica, entretanto, não se faz presente no capítulo 100 da telenovela. Apesar de contar com aproximadamente 30 inserções musicais sendo mais de 2/3 músicas instrumentais - predominam em todo o capítulo os temas livres, ou seja, arranjos que não possuem relação com as canções da trilha musical.

\title{
3.5. Avenida Brasil (2012)
}

\author{
Autoria: João Emanuel Carneiro \\ Direção-geral: Amora Mautner e José Luiz Villamarim \\ Sonoplastia: Nelson Zeitoune, Marcelo Arruda, Pedro Belo e Franklin Araújo \\ Direção Musical: Mariozinho Rocha \\ Produção Musical: Eduardo Queiroz \\ Período de exibição: 26/03/2012 até 19/10/2012 \\ Horário: 21 horas \\ $\mathrm{N}^{\circ}$ de capítulos: 179
}

\subsubsection{Sinopse $^{37}$}

Avenida Brasil conta a história de uma jovem que, desde os 11 anos, planeja um acerto de contas com a madrasta. Rita (Mel Maia), órfã de mãe, era criada, com muito amor, pelo pai Genésio (Tony Ramos). Tudo muda quando ele se casa com Carmen Lúcia, a Carminha (Adriana Esteves), uma mulher ambiciosa e dissimulada. Com Genésio, ela finge ser uma esposa doce e dedicada, mas para Rita ela é uma madrasta má.

\footnotetext{
37 Retirada do website Memória Globo. MEMÓRIA GLOBO. Disponível em: <http://memoriaglobo.globo.com/programas/entretenimento/novelas/avenida-brasil/trama-principal.htm>. Acesso em: 05 Mai. 2017.
} 
A menina entra em desespero ao descobrir, após ouvir uma conversa da madrasta ao telefone, que Carminha está armando um golpe contra seu pai: ele será abordado na saída do banco, logo após receber o pagamento pela venda da casa onde mora com a filha e a nova esposa. A transação é ideia de Carminha. Genésio titubeia, afinal a casa é herança da falecida esposa, mas decide vender o patrimônio para comprar outra casa. Carminha não arquitetou o plano sozinha. Cada passo foi acompanhado por Max (Marcello Novaes), seu amante e parceiro em golpes. Tendo ouvido o plano, Rita corre para alertar o pai, mas ele acha que a história não passa de implicância da filha com a madrasta e, aparentemente, não a leva a sério.

Ao sair do banco com o dinheiro guardado em uma mala, como sugerido por Carminha, Genésio é roubado por dois homens em uma moto. Só que, para a surpresa de todos, ele tinha enchido a mala com papéis picados e deixado o dinheiro no banco. Depois do assalto, volta à agência e esconde o dinheiro em casa, já certo de que convive com uma traidora. Para manter Carminha sob controle, mente para ela, dizendo ter sido assaltado. A mulher, uma atriz nata, finge estar muito triste com o episódio, mas celebra o que acredita ser sua vitória.

Mais tarde, depois de prometer à filha que se livraria de Carminha, Genésio a segue e flagra uma discussão dela com Max. Assim que o comparsa vai embora, Genésio briga com Carminha e acaba se ferindo. Desnorteado, perambula pela Avenida Brasil, onde é atropelado e morre no local. O motorista é Jorge Tufão (Murilo Benício), craque do Flamengo e revelado pelo Divino Futebol Clube, um time do subúrbio do Rio de Janeiro. Antes de morrer, a vítima sussurra para o jogador o nome completo de sua esposa: Carmen Lúcia Moreira de Souza. No fundo, Genésio queria denunciá-la, mas Tufão acha o contrário, que a vítima está lhe pedindo para cuidar dela. O jogador chama socorro, mas foge do local com medo de que o ocorrido atrapalhe sua carreira em ascensão.

Ao receber a notícia da morte do marido, Carminha finge a dor da viuvez, mas logo comemora o ocorrido ao lado de Max. Só resta pressionar Rita e descobrir o paradeiro do dinheiro. A menina não se retrai diante da madrasta e a enfrenta sem medo. Mas Carmen Lúcia e Max são mais espertos: enrolam Rita e conseguem pegar o dinheiro. Com a grana na mão, a vilã decide se livrar da enteada, mandando Max abandoná-la em um lixão aos cuidados de Nilo (José de Abreu). A partir de então, começa a saga de Rita, que, de 1999 a 2012, quando a novela se passa, só pensa em vingança.

Enquanto a menina enfrenta maus bocados no lixão, Carminha continua a se dar bem. Sentindo-se muito culpado pela morte de Genésio, Tufão procura a viúva. O jogador, ovacionado pela torcida e pela mídia por ter garantido o título carioca ao Flamengo, 
apresenta-se como um grande amigo do falecido e oferece ajuda a Carminha. Ela, muito esperta, logo percebe que é mentira, porque Tufão mostra insegurança ao falar de Genésio. Os dois nunca se conheceram, e Tufão só se aproximou de Carminha por se sentir responsável pela morte do marido dela. Sabendo que o jogador é rico, ela finge desespero, aproveita o fato de Tufão estar se sentido culpado e tenta seduzi-lo. Tufão cai na armadilha e, para ficar com Carminha, desmancha o noivado com a cabeleireira paraibana Monalisa (Heloísa Périssé), que sempre o incentivou na carreira.

Até conseguir ficar com Tufão, Carminha "joga pesado". Diz que vai se matar e que está esperando um filho de Genésio, sabendo que a criança é de Max. Fragilizado, o jogador se deixa levar pelas histórias da viúva, e chega a dormir com ela, enquanto ainda estava noivo de Monalisa. A paraibana, então, decide voltar para sua terra natal, sem revelar que está grávida do jogador. Ela, porém, sofre um acidente de ônibus e perde o bebê. Em seguida, adota um menino, Iran (Bruno Gissoni), e só volta ao Rio de Janeiro depois do casamento de Tufão com Carminha e do nascimento da filha dela, Ágata (Ana Karolina). Monalisa diz que não quer nada além de manter a sociedade que tem com Tufão no salão de beleza Monalisa Coiffeur, um sucesso por conta da fórmula de alisamento criada por ela. Só que, no fundo, ela é apaixonada pelo ex-noivo.

Quem acompanha a ascensão de Carminha é Max. Para manter o amante por perto, a vilã arma para que ele se case com Ivana (Letícia Isnard), irmã de Tufão. Fingindo-se meiga e prestativa, Carminha conquista toda a família do jogador, especialmente a mãe dele, Muricy (Eliane Giardini).

A verdadeira história de Carminha vai sendo revelada no decorrer da trama, mas uma pista é dada logo no começo da novela: Batata (Bernardo Simões), o primeiro filho de Carminha e Max, foi abandonado no mesmo lixão em que Rita está. Só que o destino prega uma peça nos vilões: Rita e Batata se apaixonam e prometem amor eterno um ao outro.

\subsubsection{Considerações sobre a trilha sonora}

João Emanuel Carneiro começou a escrever telenovelas para TV Globo no começo dos anos 2000. Em 2008, o autor marcou sua estreia no horário nobre da emissora com $A$ Favorita. A telenovela ganhou a atenção do público, em grande parte, devido ao mistério 
criado em torno da identidade da vilã da história. A revelação aconteceu somente após as primeiras semanas da telenovela.

Quatro anos mais tarde, a repercussão de Avenida Brasil foi ainda maior. A telenovela foi o programa mais visto em 2012, o último capítulo registrou 52 pontos de audiência, um dos maiores índices das últimas décadas ${ }^{38}$. Avenida Brasil também se destacou pela convergência entre televisão e internet, fomentando diversas discussões e comentários nas redes sociais, como o Facebook e Twitter. Os usuários se apropriaram do conteúdo da telenovela, criando uma comunidade virtual de fãs, que se dedicava diariamente a cultivar assuntos em torno do universo da telenovela.

Parte do sucesso de Avenida Brasil pode ser atribuída à sua temática. A telenovela teve como pano de fundo a nova classe média brasileira, o que proporcionou uma forte identificação com o público. A maior parte da história foi ambientada em Divino, um bairro fictício situado na periferia do Rio de Janeiro. A telenovela também procurou criar um contraponto por meio de um núcleo de personagens que pertenciam às camadas mais abastadas da sociedade carioca.

No primeiro capítulo, o bairro Divino é apresentado logo na primeira cena da telenovela. A sequência começa com a vista área da Avenida Brasil, cercada por conjuntos habitacionais. A inserção de um letreiro informa o local e o período da história: "Rio de Janeiro, 1999". Nesse trecho, ouvimos as primeiras notas da canção Meu lugar ${ }^{39}$, samba interpretado por Arlindo Cruz. Um solo de violão faz a introdução da canção e acompanha o movimento da imagem sobre o subúrbio carioca. Logo em seguida, começa o primeiro verso da canção e a letra cantada por Arlindo Cruz passa a narrar as imagens do bairro Divino:

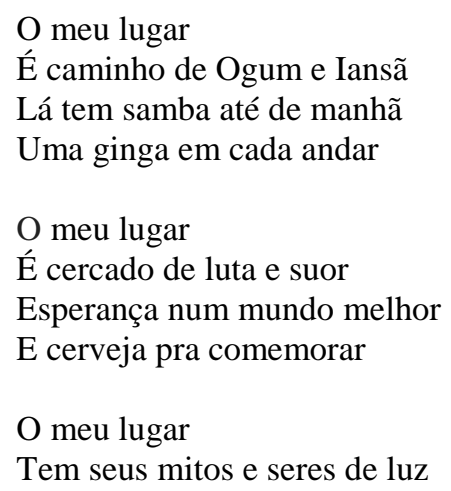

\footnotetext{
${ }^{38}$ TELEDRAMATRUGIA. Disponível em: <http://www.teledramaturgia.com.br/avenida-brasil/>. Acesso em: 18 abr. 2017.

${ }^{39}$ A versão original da canção faz referência ao bairro Madureira, que foi alterado para Divino na versão da telenovela.
} 
É bem perto de Osvaldo Cruz,

Cascadura, Vaz Lobo e Irajá

O meu lugar

É sorriso é paz e prazer

O seu nome é doce dizer

É Divino, lá laiá, é Divino, lá laiá

A primeira estrofe é composta apenas pela voz de Arlindo Cruz acompanhada por um arranjo de violão. A montagem das imagens segue o andamento lento da canção. Vemos crianças jogando bola, soltando pipa e brincando em volta de um campo de areia. $\mathrm{O}$ uso do efeito câmera lenta reforça a relação entre o ritmo do som e da imagem. A partir da segunda estrofe, novos elementos musicais são adicionados à canção. O samba se faz mais presente através do arranjo de pandeiro, tamborim e cuíca. Os cortes rápidos dos planos de imagem aceleram o ritmo da montagem, que passa a mostrar fragmentos da rotina de vida em Divino.

Ao longo da sequência, ao passo que o estilo musical da canção ajuda a construir a ambientação no subúrbio carioca, a letra cantada por Arlindo Cruz transmite os sentimentos das pessoas que vivem naquele espaço. A associação direta entre imagem e canção introduz o bairro Divino na telenovela. Ao final da sequência, enquanto vemos uma placa de sinalização de trânsito no canteiro da Avenida Brasil que indica a direção do bairro Divino, ouvimos o último verso cantado em várias vozes: "É Divino, lá laia, é Divino, lá laiá”.

A transição para a cena subsequente acontece por meio das vozes de uma torcida, que grita o nome do jogador de futebol Tufão. A canção Meu lugar é atenuada e o canto se encerra. O tema prossegue de forma instrumental, mantendo a relação da cena com o espaço do bairro Divino. Então, vemos a fachada da sede do Divino Futebol Clube. Há uma grande quantidade de pessoas aglomeradas em frente ao prédio. Uma equipe de televisão realiza uma reportagem no local e a repórter fala direto para a câmara: "Nós estamos aqui no Divino, bairro do subúrbio do Rio de Janeiro, onde o artilheiro do Campeonato Carioca desse ano, Jorge Tufão, nasceu e foi criado". A fala da repórter reitera verbalmente a apresentação do bairro Divino e introduz o personagem Tufão na narrativa. A repórter entrevista Diógenes, que conta a história de Tufão nos tempos em que ele jogava no Divino Futebol Clube. A partir desse ponto, as reportagens da televisão passam a conectar os diferentes espaços.

A primeira dessas transições ocorre durante a fala de Seu Juca, quando passamos a acompanhar a entrevista através do aparelho de televisão na casa de Tufão. A mudança da fachada do Divino Futebol Clube para o interior da casa de Tufão é auxiliada pelo encerramento da variação instrumental da canção Meu lugar. O cessar da música transfere o foco narrativo do bairro Divino para o personagem Tufão. Vemos Tufão sentado em frente à 
televisão, assistindo a entrevista de Seu Juca. Inconformado com as mentiras ditas por Juca, Tufão desliga o aparelho. A interrupção do som da televisão cria a transição para o início do diálogo entre Tufão e seus familiares. Durante o diálogo, temos a inserção de um samba. $\mathrm{O}$ ritmo agitado do cavaquinho, somado às frases de cuíca e trompete, gera um clima descontraído para a cena, colaborando com o tom de humor presente no núcleo narrativo de Tufão.

Após o diálogo, Tufão se dirige para o lado de fora da casa, onde uma multidão o aguarda. Uma equipe de televisão se aproxima e entrevista Tufão. Durante a fala do personagem, temos outra transição de cena, para o salão de beleza de Monalisa. Então, passamos a ver Tufão através de um aparelho de televisão fixado na parede do salão de beleza. A voz do personagem transita do primeiro plano para um segundo plano sonoro, passando a atuar como ruído ambiente no espaço do salão. A continuidade da fala de Tufão cria a simultaneidade temporal entre as duas cenas. A permanência da música após a transição de cena preserva o tom de humor, mesmo com a troca dos espaços.

Monalisa assiste atentamente à entrevista de Tufão, que anuncia publicamente a data do casamento. Monalisa é namorada de Tufão e fica surpresa com a notícia. Como ela não foi informada do casamento, desconfia que o jogador a esteja traindo. A cena termina com a reclamação de uma cliente - que interrompe a divagação de Monalisa - dizendo que o produto químico que foi aplicado na cabeça dela está "formigando". A situação cômica é reforçada pela música instrumental, que encerra a cena com uma variação decrescente de uma nota executada por um instrumento de sopro.

A cena seguinte acontece no interior da casa onde moram Genésio, Carminha e Rita. Enquanto Rita brinca com um carrinho de bombeiro e uma boneca, vemos em uma televisão, ao fundo, o repórter encerrando a reportagem sobre Tufão. Na troca de cena, a música instrumental é interrompida e o som proveniente da televisão é atenuado gradativamente. Essa transição sonora cria a passagem do núcleo narrativo de Tufão para o de Genésio, Carminha e Rita. A voz de Rita predomina no início da cena. A menina produz com a boca a sirene do carrinho de bombeiro e o som emitido por ela ecoa pelos cômodos, compondo o ambiente da casa. Carminha fica irritada com o barulho gerado pela menina e, abruptamente, solta um grito que interrompe o ruído produzido pela menina. Logo em seguida, a inserção de uma música, composta por arranjos orquestrais, acrescenta tensão à cena e marca a deflagração do conflito entre as duas personagens.

A partir desse ponto, a música começa a pontuar a ação das personagens. Conforme a discussão entre Carminha e Rita evolui, novos elementos musicais são inseridos na cena. $\mathrm{O}$ 
primeiro momento ocorre quando Rita joga uma peça de vidro no chão e a dinâmica dos instrumentos aumenta a intensidade da música. Rita arremessa outra peça de vidro no chão e, dessa vez, um efeito sonoro grave é inserido junto com o ruído proveniente do vidro quebrando. A música realiza um movimento crescente, evidenciando o agravamento da briga entre Carminha e Rita.

Em seguida, a música volta aos arranjos inicias, mas com o acréscimo de um violino que sustenta uma nota aguda. Carminha reage à ação de Rita rasgando a boneca da menina. A menina começa a gritar e a chorar. Carminha fica ainda mais irritada, segura Rita pelo braço e a joga no chão. A música realiza um acento por meio dos ataques dos instrumentos de corda e das batidas dos instrumentos percussivos. Rita cai no chão, levanta-se e arremessa comida no rosto de Carminha. Nesse instante, temos novamente um acento da música que, a partir desse ponto, fica mais agitada com a cadência dos instrumentos de cordas. A tensão da cena aumenta e Carminha ameaça bater em Rita, mas é interrompida com a chegada de Genésio em casa. O ruído da porta abrindo é reforçado por um novo acento da música. Com a entrada de Genésio em cena a música retorna à forma inicial. A diminuição da dinâmica dos instrumentos também acompanha a mudança de comportamento de Carminha que, na frente de Genésio, finge ser a vítima de toda a situação.

Ao longo do primeiro capítulo, a trama de Genésio, Carminha e Rita é regida pelos temas orquestrais. A inserção das músicas colabora com a tensão proveniente do conflito entre o bem e o mal, presente nas relações entre os personagens. Carminha é a vilã da história e planeja roubar o dinheiro de Genésio. Rita, filha de Genésio, desde o início da história, convive com as maldades de Carminha. Rapidamente, a menina descobre que a madrasta quer roubar o dinheiro da família. Até a metade do capítulo, Genésio não percebe as reais intenções de Carminha e os temas orquestrais se restringem à relação entre Rita e Carminha.

A inserção de Genésio nos conflitos travados entre Rita e Carminha acontece após o personagem realizar a venda da casa. Na saída do banco, Genésio é assaltado e tem a confirmação de que está convivendo com uma criminosa. A constatação de Genésio é regida por um tema orquestral, que conduz o andar desolado do personagem de volta para a casa. Nesse trecho, temos uma música meta-diegética que transmite o estado psicológico de Genésio, o qual está abalado com a traição de Carminha. Quando Genésio entra em casa, Carminha se assusta com sua presença. A execução de um acorde dissonante pontua a ação e marca o momento em que Genésio se coloca em oposição à Carminha. A partir desse ponto, os temas orquestrais passam a reger a relação de Genésio com Carminha. 
Ainda no âmbito da trilha musical, também observamos no primeiro capítulo de Avenida Brasil a utilização de duas canções associadas aos personagens: Estória de nós dois, interpretada por José Augusto, tema de Tufão e Monalisa; e a canção Reza, interpretada por Rita Lee, tema de Cadinho.

A primeira inserção da canção Estória de nós dois ocorre em uma das cenas no salão de beleza de Monalisa. Os ruídos provenientes dos secadores de cabelo constroem o ambiente do salão. Monalisa penteia o cabelo de uma cliente, enquanto dialoga com uma amiga de trabalho. A personagem procura ignorar o anúncio do casamento de Tufão na televisão, mas não resiste e começa a chorar. Nesse momento, ouvimos os primeiros acordes de Estória de nós dois e Monalisa desabafa sobre seus sentimentos em relação a Tufão. A execução da introdução da canção marca na narrativa o início da relação amorosa entre Tufão e Monalisa.

Em seguida, o clima romântico é interrompido por uma voz off, que solicita a atenção de todas as pessoas que estão naquele local. O timbre da voz está alterado, remetendo ao som proveniente de um dispositivo eletroacústico. O tema Estória de nós dois cessa. Monalisa e sua amiga interrompem o diálogo e passam a prestar atenção na voz. Do lado de fora do salão de beleza, vemos Silas em cima de um caminhão de som que passa pela rua. A voz do personagem transita do espaço off para on e descobrimos que a fonte sonora é o alto-falante do caminhão. A inserção de uma música instrumental auxilia a transição das cenas. $\mathrm{O}$ arranjo de pandeiro e surdo marca o ritmo do samba e as frases musicais executadas pelos instrumentos de sopro colaboram com o tom de humor presente nas falas de Silas. Ele anuncia o nome de Monalisa e transmite o pedido de casamento de Tufão para ela. Nesse instante, temos uma transição para o interior do salão e a voz de Silas volta para o espaço off. A continuidade da fala do personagem e da música conecta os dois espaços. Monalisa fica inconformada com o que está ouvindo e vai para o lado de fora do salão acompanhada da amiga. Do lado de fora, há uma grande quantidade de pessoas que recebem Monalisa com aplausos e gritos. Em cima do Caminhão, Silas insiste com o pedido de casamento de Tufão. Monalisa não está compreendendo a situação e fica irritada por achar que as pessoas estão fazendo piada com ela. A confusão termina com a chegada de Tufão, que pessoalmente pede Monalisa em casamento. Sem ainda entender o que está acontecendo, Monalisa fica desconfiada. Tufão esclarece o mal entendido e diz que não há outra pessoa em sua vida além dela. A inserção do tema do casal retoma o clima romântico e concretiza a união entre as personagens. Dessa vez, a canção é executada na versão original e ouvimos os três primeiros versos cantados por José Augusto. 
O nosso amor conhece bem a gente,

Nem igual nem diferente

Não é antes nem depois

O nosso amor é o que a gente sente.

Nem culpado ou inocente nessa estória de nós dois.

O nosso amor não é obra do acaso.

E um plano desenhado coisa simples de entender

Enquanto Tufão refaz o pedido de casamento para Monalisa, a letra da canção transmite os sentimentos do personagem. A cena termina com um beijo do casal. A intensidade da canção aumenta e ouvimos as pessoas ao redor ovacionando a união entre Tufão e Monalisa.

A inserção da canção Reza ocorre na introdução de Cadinho na telenovela. O personagem faz parte do núcleo rico da história e a sequência que o introduz na narrativa começa com imagens aéreas de bairros nobres do Rio de Janeiro. Enquanto vemos as construções de alto padrão em meio às paisagens naturais da cidade, ouvimos o rock cantando por Rita Lee, marcado por notas distorcidas de guitarra e pelo ritmo mais acelerado conduzido pela bateria. No interior de um quarto luxuoso, vemos Cadinho acordando. A história do personagem também está permeada pelo humor. Os elementos sonoros são utilizados para reforçar as situações cômicas vividas pelo personagem. Por exemplo, na cena em que ele está negociando a venda da empresa com um grupo de empresários. Cadinho planeja vender a empresa por 20 milhões. Mas durante as negociações o grupo de empresários oferece 25 milhões. A surpresa do personagem diante do valor acima do esperado é acentuada por um efeito sonoro de caixa registradora. A construção sonora rompe com a sensação de verossimilhança e o ruído acentua a ação de forma caricata. Cadinho é ambicioso, diz que o valor está aquém do esperado e oferece a empresa por 40 milhões. Nesse momento, um novo efeito sonoro sublinha o valor proposto pelo personagem. O movimento decrescente das frequências do efeito sonoro gera um som semelhante ao de instrumento musical desafinando, remetendo à sonoridade de desenhos animados. Assim, os ruídos reforçam o tom cômico que permeia a narrativa de Cadinho.

A utilização dos ruídos para acentuar as ações dos personagens também pode ser observada na cena em que Genésio desmascara Carminha. Após Genésio descobrir que Carminha planejava roubá-lo, ele a segue até o ponto de encontro com Max. O percurso é regido por ruídos de sala e música, não há diálogos. A perseguição é embalada pela pulsação das batidas graves da música e a dinâmica crescente dos instrumentos fornece o suspense da cena. Ao longo do trajeto, os ruídos de sala reforçam os movimentos da imagem e pontuam a 
ação das personagens. Carminha chega à laje do Jaci, onde Max a espera. A pulsação da música repousa em uma nota grave criando a transição para o início do diálogo entre os dois. A sustentação da nota grave mantém o clima de tensão e suspense na cena.

Genésio permanece escondido atrás de uma grade e ouve toda a conversa entre Carminha e Max. Carminha faz menção a Genésio e revela seu desprezo pelo personagem. Nesse instante, a inserção de uma música orquestral reitera o tema do conflito entre Genésio, Carminha e Rita. Max vai embora, Genésio aparece e surpreende Carminha. Os dois discutem e acabam partindo para a briga. O ruído do primeiro golpe de Carminha em Genésio é o ponto de transição para o aumento da intensidade da música orquestral. Após dar um chute em Genésio, Carminha tenta fugir. Genésio a agarra na beira da escada e Carminha aplica outro golpe nele. Genésio cai escada abaixo. Quando ele atinge o último degrau, vemos Carminha imponente no topo da escada através de um ângulo baixo de câmera. Nesse momento, ouvimos um trovão e a música diminui de intensidade. Carminha se aproxima lentamente de Genésio e a música sustenta uma nota aguda. Ela passa por ele e diz: "Vai para o inferno!". Após a fala da personagem, ouvimos outro trovão e começa a chover. Além de o ruído antecipar um evento narrativo, a chuva, ele também atua em função das ações de Carminha. Enquanto vemos as atitudes perversas da personagem, o som grave do trovão reforça o poder da personagem.

Ao final do capítulo, os ruídos assumem o centro da narrativa na construção da cena da morte de Genésio. Após sofrer as agressões de Carminha, o personagem caminha por uma rua da cidade sob a água da chuva. Devido à queda da escada, ele anda cambaleando e não aparenta estar bem fisicamente. Paralelamente, vemos Tufão andando de carro e, no rádio do automóvel, toca a canção Verdade, interpreta por Zeca Pagodinho. Tufão dirige sob a chuva intensa, cantando euforicamente a canção. Quando o personagem realiza um movimento para desligar o rádio, repentinamente ouvimos um ruído grave de batida, que é acompanhado pelo som de pneus derrapando no asfalto. Após os ruídos abruptos, ouvimos apenas o som da água da chuva caindo sobre o carro e o deslizar dos limpadores de para-brisa. A imagem do parabrisa mostra uma grande quantidade de sangue misturada à água da chuva. Enquanto o líquido escorre pelo vidro, temos a inserção de uma música. O longo ataque dos instrumentos de corda insere lentamente o suspense na cena. Continuamos ouvindo a pulsação proveniente do movimento dos limpadores de para-brisa. A imagem se desloca para o retrovisor do veículo e vemos Genésio estirado no meio da rua. Tufão desce do carro, caminha em direção a Genésio e o ruído da chuva se faz mais presente. Tufão se abaixa ao lado de Genésio e tenta conversar com ele. Genésio está severamente machucado e tenta falar sobre Carminha para Tufão. No 
entanto, a única coisa que Genésio consegue articular é o nome completo de Carminha. Ao tentar completar a frase, Genésio morre repentinamente. Após o último suspiro do personagem, ouvimos o estrondo de um trovão. O ruído retoma a figura de Carminha na cena e simboliza a vitória da personagem diante da morte de Genésio.

Os ruídos também são elementos fundamentais na construção da narrativa da cena inicial do capítulo 100 de Avenida Brasil. A sequência começa com Rita escondida em um sótão. O ruído dos grilos compõe o espaço da cena e fornece a sensação do ambiente noturno e tranquilo que cerca a casa. Através da fresta de uma entrada de ar localizada no teto da sala, Rita espia e fotografa o encontro amoroso entre Carminha e Max. A cada foto tirada por Rita, ouvimos o ruído da câmera fotográfica registrando os beijos e os abraços do casal. O clima de suspense é intensificado por uma música instrumental que fornece tensão à cena por meio da harmonia executada pelos instrumentos. Além disso, a pulsação das batidas graves da percussão acentua a situação de perigo que Rita enfrenta diante da possibilidade de ser descoberta por Carminha e Max.

Após tirar as fotos, Rita sai do sótão pelo lado de fora da casa, mas ao pisar no telhado derruba uma telha que está solta. O ruído gerado pela telha batendo no chão é ouvido no interior da casa por Carminha e Max. Ao perceber que o barulho pode denunciar sua presença, Rita desce rapidamente do telhado e foge correndo. Carminha fica desconfiada e convence Max a sair da casa com ela para conferir o que está acontecendo. Do lado de fora, eles não encontram ninguém. Max procura acalmar Carminha, que permanece desconfiada e insiste em dizer que havia outra pessoa na casa. Ouvimos um ruído em off de um automóvel. Após a partida do motor do veículo a intensidade do ruído diminui gradativamente até cessar por completo. O movimento do som do automóvel constrói a fuga de Rita fora do quadro da imagem, criando sonoramente o deslocamento da personagem para longe do espaço da casa. Ao ouvir o ruído, Carminha insiste em acreditar que havia outra pessoa na casa. No entanto, Max diz que o som do automóvel provém da estrada que passa próxima ao local. Por fim, Carminha acaba se conformando e volta para dentro da casa acompanhada de Max.

No âmbito das músicas, a estrutura do capítulo 100 é semelhante à desenvolvida ao longo do capítulo 1. A trama em torno de Carminha e Rita, por exemplo, prossegue regida pelos temas orquestrais, que geram a tensão para o conflito travado entre elas. Em alguns momentos, os ataques dos instrumentos acentuam as ações das personagens, tal como nas sequências do capítulo 1 descritas anteriormente. Já a história de Tufão continua marcada pelo ritmo do samba, que auxilia na criação do tom de humor que permeia o núcleo narrativo do personagem. Cadinho, por sua vez, segue associado à canção Reza, de Rita Lee. A canção é 
utilizada em dois momentos no capítulo 100. O primeiro ocorre quando Cadinho e Alexia finalmente conseguem um momento a sós após uma longa discussão com Pilar, sogra de Cadinho. O casal vai para o quarto, Alexia se deita na cama e Cadinho vai em direção a ela. Ele beija e abraça a esposa, mas acaba dormindo repentinamente. Alexia fica inconformada com a atitude do marido. A segunda inserção da canção Reza acontece quando Cadinho encontra Noêmia em uma exposição no museu. Os dois entram em uma instalação artística, onde acabam se beijando. A canção conecta os dois momentos da narrativa e reforça o adultério cometido por Cadinho, comportamento que marca o personagem ao longo da telenovela. 


\section{Considerações finais}

Por meio do panorama histórico apresentado no início desse trabalho mapeamos o desenvolvimento do aparato técnico sonoro televisivo, bem como as principais transformações ocorridas na produção da trilha sonora das telenovelas da TV Globo. O percurso traçado revelou a preocupação da emissora em modernizar seu processo produtivo, acompanhando as inovações que surgiram no mercado entre os anos de 1950 até o início do século XXI. Buscando constantemente aprimorar e renovar seus processos de criação e realização a TV Globo lançou mão de pesquisas e investimentos em tecnologias recémdesenvolvidas que, por diversas vezes, foram incorporadas pela emissora num curto espaço de tempo. Exemplo disso são os equipamentos portáteis, que surgiram no final da década de 1960 e foram colocados em uso na emissora ainda no começo dos anos 1970, ou as Digital Audio Workstation (DAW) que surgiram como ferramentas profissionais em meados dos anos 1980 e passaram a ser usadas na sonoplastia das telenovelas logo na década seguinte.

A implantação da primeira $D A W$ na TV Globo, o Audioframe, foi uma das marcas do início da digitalização do som das telenovelas. Esse processo, que começou ainda nos anos 1990, consolidou-se no começo do século XXI quando a tecnologia digital atingiu a televisão como um todo: produção, transmissão e recepção. Nesse período, a TV Globo reestruturou seu parque tecnológico, desencadeando uma profunda transformação do aparato técnico sonoro. Destacamos, sobretudo, a implantação de gravadores digitais de som multipista na captação do som direto; a adoção de DAW mais modernas, como o Pro Tools; e a adequação à TV Digital e à legislação de Loudness, que demandou um amplo estudo e investimento da emissora, resultando na reformulação da concepção, processamento e transmissão do áudio dos programas.

Essa renovação tecnológica foi acompanhada por uma ampliação do departamento de som da emissora. Os processos da produção sonora se expandiram e houve um aumento no quadro de profissionais. Na finalização do som, a quantidade de pessoas atuando em uma mesma telenovela praticamente dobrou, passando de duas para até quatro. Assim, ocorreu uma especialização das etapas e o processo passou a contar com profissionais dedicados em cada área: editor de áudio, sonoplasta de efeitos, sonoplasta de foley e técnico de mixagem.

Destacamos, também, a criação do produtor de áudio que, aos moldes do sound designer no cinema, passou a acompanhar todo o processo de produção da telenovela, atuando no planejamento, realização e finalização do som. Além de realizar a conexão entre as etapas 
da produção sonora, esse profissional dialoga com as outras áreas da realização, fomentando as discussões sobre o som nos processos criativos da telenovela.

Esse investimento em profissionais tem sido a postura da TV Globo desde a sua inauguração. Na década de 1960, por exemplo, a contratação de Geraldo José representou essa procura da emissora por mão de obra especializada. Geraldo José levou toda a sua experiência adquirida no rádio e no cinema para dentro da TV Globo, montando um setor especializado na produção de ruídos. Cerca de vinte anos depois, a emissora investiu novamente nessa área criando um departamento dedicado à produção da banda internacional de som.

Toda essa evolução do aparato técnico e expansão dos processos da produção sonora caminharam, lado a lado, com a incessante busca da TV Globo em renovar esteticamente suas telenovelas. Ao longo das décadas, com a inovação das narrativas e o aperfeiçoamento das construções audiovisuais, os desenhos sonoros foram ganhando traços e contornos cada vez mais apurados. Assim, as telenovelas foram incorporando novas sonoridades e apresentando formas mais elaboradas de utilizar as vozes, ruídos e músicas para desenvolver as histórias e articular as propostas de cada obra.

Essas funções desempenhadas pelos elementos sonoros foram detalhadas por meio da análise do capítulo 1 e do capítulo 100 de Pecado Capital, Roque Santeiro, Renascer, Senhora do Destino e Avenida Brasil. Inicialmente, discutimos as diferenças entre o capítulo 1 e o capítulo 100, que revelaram produtos televisivos com linguagens distintas. No capítulo 100 das cinco telenovelas, a voz é o elemento sonoro que predomina na narrativa, desenvolvendo a história por meio das falas das personagens. Com as vozes assumindo a centralidade, ruídos e músicas passam a ocupar um segundo plano da trilha sonora. Essa estrutura vococêntrica ecoa, na verdade, uma característica própria da linguagem televisiva, que nasceu a partir das experiências de meios "falantes", como o teatro e o rádio. De acordo com Salinas:

\footnotetext{
A fala é o som por excelência na televisão, tudo fala, tudo é falado e fala-se muito. A programação televisiva está superpovoada de programas falantes: entrevistas, debates, telejornais, documentários, esportes e até os programas (e emissoras) musicais preferem as músicas cantadas. A telenovela não foge desse padrão "falatório", pois em forma de diálogos tudo pode ser falado e contado em histórias. (SALINAS, 1994, p. 80)
}

O vococentrismo é, então, o próprio recurso da comunicação televisiva, que, por estar envolta nos afazeres cotidianos dos telespectadores, recorre ao discurso racional, lógico e 
direto das palavras faladas. Para Chion, essa característica faz da televisão uma espécie de "rádio ilustrado":

\footnotetext{
Dizer da televisão - sem, aliás, intenção pejorativa - que é um rádio ilustrado [...] é lembrar que o som, principalmente o som da fala, está nela sempre em primeiro plano, nunca está fora de campo e está sempre lá, no seu lugar, não tendo necessidade da imagem para ser localizado. (CHION, 2011, p. 125)
}

Nessa relação entre o verbal e o visual, a concretude trazida pelo significado das palavras dá ao som da voz autonomia em relação à imagem, permitindo que o dito possa ser compreendido sem ser visto. "Na televisão, nada é mais normal do que as conversas entre pessoas, sem que esta conversação se refira obrigatoriamente àquilo que se passa em simultâneo no ecrã [...] O televisivo é um acréscimo de imagem”. (CHION, 2011, p. 126)

No caso específico das telenovelas, no entanto, há outras questões que precisam ser consideradas, sobretudo, as peculiaridades do processo de produção. Retomando o capítulo 100, é importante ressaltar que, por ser um capítulo intermediário, ele é produzido no ritmo acelerado da produção diária da telenovela. Consequentemente, as etapas de criação precisam ser otimizadas, de modo que as possibilidades de uma maior elaboração das construções audiovisuais são sensivelmente reduzidas. No âmbito da finalização de som, por exemplo, o prazo médio para finalizar um capítulo é de apenas um dia de trabalho.

Por outro lado, o capítulo 1 é produzido com maior antecedência, dispondo de mais tempo de planejamento, realização e finalização, o que aumenta a viabilidade da criação de formas audiovisuais mais complexas. Dessa forma, de Pecado Capital à Avenida Brasil, o capítulo 1 fez transparecer a preocupação e a busca dos realizadores em propor narrativas que transbordam o discurso verbal da linguagem vococentrada. Os desenhos sonoros presentes nesses capítulos exploram outras potencialidades do som, principalmente, sua dimensão mais subjetiva. As vozes, ruídos e músicas passam a atuar com maior intensidade no sensorial, empático, afetivo, aquilo que, muitas das vezes, extrapola o domínio da razão. As imagens, por sua vez, deixam de se concentrar apenas nas talking heads e procuram desbravar outros ângulos, planos e movimentos que compõem uma poética visual.

Conforme demonstramos, no capítulo 1 das cinco telenovelas, som e imagem estabelecem uma imbricada relação, um entrelaçamento que torna o sonoro e o imagético indissociáveis. Através dessa linguagem a telenovela aprofunda a experiência audiovisual, requerendo uma maior interação do telespectador - isso é, uma participação ativa e conjunta da audição e da visão. Tal como a "audiovisão" defendida por Chion, em que o ver influencia 
o ouvir e vice-versa. De acordo com ele, "no contrato audiovisual, uma percepção influencia a outra e a transforma: não vemos a mesma coisa quando ouvimos; não ouvimos a mesma coisa quando vemos". (CHION, 2011, p. 7, grifo do autor)

Nessa relação entre som e imagem não existe uma hierarquia, ambos os elementos são igualmente imprescindíveis para a experiência audiovisual. De acordo com Rodríguez:

\footnotetext{
No contexto da linguagem audiovisual, o som não enriquece imagens, mas modifica a percepção global do receptor. $O$ áudio não atua em função da imagem $e$ dependendo dela; atua como ela e ao mesmo tempo que ela, fornecendo informações que o receptor processará de modo complementar em função de sua tendência natural à coerência perceptiva. (RODRÍGUEZ, 2006, p. 276-77)
}

Dessa forma, a trilha sonora da telenovela não se restringe apenas às falas, ao discurso racional, lógico e direto das palavras. Na verdade, os elementos sonoros também compõem a dimensão não verbal da telenovela, o estímulo sensorial que aciona a subjetividade do telespectador, encontra sentido no seu imaginário e o envolve no universo narrativo.

Para este pesquisador, o estudo da trilha sonora da telenovela representou a incursão em um universo pouco conhecido. Até então, a minha relação com as telenovelas vinha apenas da experiência de telespectador, daqueles momentos em que eu sentava no sofá ao lado da minha família para acompanhar o desenrolar das tramas. Assim, ao adotar a telenovela como objeto de estudo, essa posição confortável começou a dar lugar às inquietações que movem um investigador.

Ao longo do percurso, surgiram também as incertezas, principalmente devido à ausência de uma vasta bibliografia sobre as poéticas e as técnicas do som na telenovela, o que me levou também a questionar se as telenovelas viabilizariam um estudo amplo das formas criativas do uso do som na televisão. Assombrado pelas dúvidas, segui em frente e debruceime sobre o material das telenovelas selecionadas em busca de respostas. Para minha surpresa, elas vieram logo no início das análises, quando me deparei com Pecado Capital. Fiquei entusiasmado com a forma como os ruídos protagonizavam a narrativa, construindo sequências inteiras, articulando a temática da telenovela. Tal constatação fez minhas incertezas repousarem na esperança de que o caminho a ser percorrido com as telenovelas seria extremamente produtivo. O que se confirmou ao final da pesquisa, com a observação da riqueza de formas de utilização das vozes, ruídos e músicas de Pecado Capital à Avenida Brasil, não pairando dúvidas sobre o uso criativo do som nas telenovelas.

Por fim, a dimensão sonora da televisão demonstrou ser um vasto campo a ser estudado, mas que permanece pouco explorado, demandando um maior envolvimento dos 
pesquisadores para ser melhor compreendido e sistematizado. Espero que essa pesquisa venha a contribuir com os estudantes, profissionais e pesquisadores que se proponham a traçar novos caminhos dentro dessa área do conhecimento. 


\section{REFERÊNCIAS}

\section{Bibliografia}

ALKIN, Glyn. Operações de som em televisão. Lisboa: Presença, 1980.

ALVES, Bernardo Marquez. Os estudos do som no cinema: evolução quantitativa, tendências temáticas e o perfil da pesquisa brasileira contemporânea sobre o som cinematográfico. São Paulo, 2013. Dissertação Mestrado em Ciências da Comunicação Escola de Comunicação e Artes da Universidade de São Paulo.

BALAN, Willians Cerozzi. Um Breve Olhar pela Evolução da TV no Brasil: parte 1 do início a cor. São Paulo: Revista Produção Profissional, Editora Bolina, 2012.

BAPTISTA, André. Funções da música no cinema: contribuições para a elaboração de estratégias composicionais. Belo Horizonte, 2007. Dissertação de Mestrado em Música Escola de Música da Universidade Federal de Minas Gerais.

BELLI, Zenilda Poci Banks Leite. Radionovela: análise comparativa na radiodifusão na década de 40. São Paulo, 1980. Dissertação Mestrado em Ciência da Comunicação Departamento de Relações Públicas e Propaganda da Escola de Comunicação e Artes da Universidade de São Paulo.

BORDWELL, David; THOMPSON, Kristin. Film art: an introduction. 2.ed. Nem York: McGraw-Hill, 1986.

BRANDÃO, Cristina. O grande teatro tupi do Rio de Janeiro: o teleteatro e suas múltiplas faces. 1.ed. Rio de janeiro: Editora UFJF, 2005.

BRYAN Guilherme, VILLARI, Vincent. Teletema: volume I 1964 a 1989. A história da música popular através da teledramaturgia brasileira. 1.ed. São Paulo: Dash, 2014.

BUTCHER, Pedro. A dona da história: origens da Globo Filmes e seu impacto no audiovisual brasileiro. Rio de Janeiro, 2006. Dissertação Mestrado em Comunicação Escola de Comunicação, Universidade Federal do Rio de Janeiro.

CHION, Michel. A audiovisão: som e imagem no cinema. Tradução de Pedro Elói Duarte. 1.ed. Rio de Janeiro: Edições texto \& grafia: 2011. 
FILHO, Daniel. O circo eletrônico: fazendo TV no Brasil. 1.ed. Rio de Janeiro: Jorge Zahar, 2001.

FLÔRES, Virginia. O cinema: uma arte sonora. São Paulo: Annablume, 2013

GORBMAN, Claudia. Unheard melodies: narrative film music. London: BFI, 1987.

KROPF, Maria Helena. Contribuição da voz e da fala ao ator da telenovela. São Paulo, 1990. Dissertação Mestrado em Ciências da Comunicação - Escola de Comunicação e Artes da Universidade de São Paulo.

MACHADO, Arlindo. A televisão levada a sério. 5.ed. São Paulo: Senac, 2009.

MATTOS, Sérgio Augusto Soares. História da televisão brasileira: uma visão econômica, social e política. 2. ed., Rio de Janeiro: Editora Vozes, 2002.

MOURA, Fernando. Rede Globo adapta sua programação a nova lei do Loudness. Revista SET n⿳10135, 2013. Disponível em: http://www.set.org.br/revista-da-set/rede-globo-adapta-suaprogramacao-a-nova-lei-de-loudness/ Acesso em: 5 Dez. 2016.

REGHINI, Rafael Roso. A trilha sonora da telenovela brasileira: da criação à finalização. São Paulo, 2001. Tese de Doutorado em Ciências da Comunicação - Escola de Comunicação e Artes da Universidade de São Paulo.

RIBEIRO, Ana Paula Goulart; SACRAMENTO, Igor; ROXO; Marco, (orgs.). História da Televisão no Brasil. São Paulo: Contexto, 2010.

RODRÍGUEZ, Ángel. A dimensão sonora da linguagem audiovisual. Tradução de Rosângela Dantas; Revisão técnica de Simone Alcantara Freitas. São Paulo: Editora Senac São Paulo, 2006.

SÁ, Simone Pereira de; COSTA, Fernando Morais da, (orgs.). Som + imagem. Rio de Janeiro: 7Letras, 2012.

SALINAS, Fernando de J.G. Da "dupla-dinâmica" som-imagem: uma aproximação teórica ao som na televisão - análise do som em nove programas da televisão brasileira. São Paulo, 1988. Dissertação de Mestrado em Ciências da Comunicação - Escola de Comunicação e Artes da Universidade de São Paulo. 
SALINAS, Fernando de J.G. O som na telenovela: articulações som e receptor. São Paulo, 1994. Tese de Doutorado em Ciências da Comunicação - Escola de Comunicação e Artes da Universidade de São Paulo.

SALVADOR, Roberto. A era do radioteatro: o registro da história de um gênero que emocionou o Brasil. 1.ed. Rio de Janeiro: Gramma, 2010.

SEDEK, José Roberto. Telenovela: um olhar do cinema. São Paulo: Summus, 2008.

SILVA, Flávio Luiz Porto e. O teleteatro paulista nas décadas de 50 e 60. São Paulo: Idart, 1981.

SOUZA, Cláudio Mello e. 15 anos de história. Rio de Janeiro: Rede Globo, 1984.

SOUZA, João Baptista Godoy de. Procedimentos de trabalho na captação de som direto nos longas-metragens brasileiros Contra todos e Antônia: a técnica e o espaço criativo. São Paulo, 2010. Tese de Doutorado em Ciências da Comunicação - Escola de Comunicação e Artes, Universidade de São Paulo.

\section{Sites}

ARTESÃOS DO SOM. Disponível em: <http://www.artesaosdosom.org>. Acesso em: 10 de out. 2015.

BAND. Disponível em: <http://www.band.uol.com.br/> . Acesso em: 03 de outubro de 2017.

COMPÓS. Disponível em: <http://www.compos.org.br/>. Acesso em: 10 out. 2015.

EXPERIMENTAL TELEVISION CENTER. Disponível em: <http://www.experimentaltvcenter.org/>. Acesso em: 14 mai. 2017.

FUNDAÇÃO ARMANDO ALVARES PENTEADO. Acervo Biblioteca FAAP. Disponível em: <http://www.faap.br/biblioteca>. Acesso em: 10 out. 2015.

GEARSLUTZ. Disponível em: 〈https://www.gearslutz.com〉. Acesso em: 14 mai. 2017.

INTERCOM. Disponível em: <http://www.portalintercom.org.br/>. Acesso em: 10 out. 2015. 
PONTIFÍCIA UNIVERSIDADE CATÓLICA DE SÃO PAULO. LUMEN: Acervo das bibliotecas PUC-SP. Disponível em: <http://www.pucsp.br/biblioteca>. Acesso em: 10 out. 2015.

LABGUYSWORLD. Disponível em: 〈http://www.labguysworld.com>. Acesso em: 14 mai. 2017.

MEMÓRIA GLOBO. Disponível em: <http://memoriaglobo.globo.com>. Acesso em: 05 mai. 2017.

MEMÓRIA ROBERTO MARINHO. Disponível em: 〈http://www.robertomarinho.com.br〉. Acesso em 14 mai. 2017.

SOCINE. Disponível em: <http://www2.socine.org.br/> . Acesso em: 10 out. 2015.

UNIVERSIDADE DE SÃO PAULO. Sistema Integrado de Bibliotecas. DEDALUS: banco de dados bibliográficos da USP. Disponível em: <http://dedalus.usp.br>. Acesso em: 10 out. 2015.

UNIVERSIDADE ESTADUAL PAULISTA. ATHENA: banco de dados bibliográficos da UNESP. Disponível em: <https://www.athena.biblioteca.unesp.br/>. Acesso em: 10 out. 2015.

UNIVERSIDADE DE CAMPINAS. Sistema de Bibliotecas da Unicamp. SBU: banco de teses e dissertações da UNICAMP. Campinas. Disponível em: <http://www.bibliotecadigital.unicamp.br/>. Acesso em: 10 out. 2015.

UNIVERSIDADE FEDERAL DE SÃO CARLOS. Repositório Institucional UFSCar. Disponível em: <https://repositorio.ufscar.br/>. Acesso em: 10 out. 2015.

UNIVERSIDADE FEDERAL DE PERNANBUCO. Sistema Integrado de Bibliotecas. RI: Repositório Institucional da UFPE. Disponível em: < http://repositorio.ufpe.br/>. Acesso em: 10 out. 2015.

UNIVERSIDADE FEDERAL DO RIO GRANDE DO SUL. Sistema de Bibliotecas da Universidade Federal do Rio Grande do Sul. SBUFRGS. Disponível em: <https://www.ufrgs.br/bibliotecas/>. Acesso em: 10 out. 2015.

UNIVERSIDADE FEDERAL DO RIO DE JANEIRO. Sistema de Bibliotecas e Informação. SIBI. Disponível em: <http://www.sibi.ufrj.br/>. Acesso em: 10 out. 2015. 
UNIVERSIDADE FEDERAL DE MINAS GERAIS. Biblioteca Digital de Teses e Dissertações da UFMG. Disponível em: <http://www.bibliotecadigital.ufmg.br/>. Acesso em: 10 out. 2015.

\section{Videografia}

AVENIDA BRASIL. Autoria: João Emanuel Carneiro. Direção-Geral: Amora Mautner; José Luiz Villamarim. Direção: Gustavo Fernandez; Joana Jabace; Paulo Silvestrini; Thiago Teitelroit; Andre Camara. Rio de Janeiro: TV Globo, 2012. Suporte Digital. Som, cor, 179 capítulos.

PECADO CAPITAL. Autoria: Janete Clair. Direção: Daniel Filho. Rio de Janeiro: TV Globo, 1975. Betacam SP. Som, cor, 167 capítulos.

RENASCER. Autoria: Benedito Ruy Barbosa. Direção: Luiz Fernando Carvalho; Emílio di Biasi; Mauro Mendonça Filho. Rio de Janeiro: TV Globo, 1993. Betacam SP. Som, cor, 213 capítulos.

ROQUE SANTEIRO. Autoria: Dias Gomes. Coautoria: Aguinaldo Silva. Colaboração: Marcílio Moraes; Joaquim Assis. Supervisão: Daniel Filho. Direção: Paulo Ubiratan; Jayme Monjardim; Gonzaga Blota; Marcos Paulo. Direção-geral: Paulo Ubiratan. Rio de Janeiro: TV Globo, 1985. Betacam SP. Som, cor, 209 capítulos.

SENHORA DO DESTINO. Autoria: Agnaldo Silva. Direção: Luciano Sabino; Marco Rodrigo; Cláudio Boeckel. Direção-geral: Wolf Maya. Rio de Janeiro: TV Globo, 2004. Betacam Digital. Som, cor, 220 capítulos

\section{Entrevistas}

BARROS, Aroldo. Entrevista concedida ao autor. São Paulo, 03 de agosto de 2016. (A entrevista encontra-se transcrita no apêndice B)

CHALITA, Thanus. Entrevista concedida ao autor. São Paulo, 15 de dezembro de 2016. (A entrevista encontra-se transcrita no apêndice B)

FILHO, Guerra Peixe. Entrevista concedida ao autor. São Paulo, 16 de dezembro de 2016. (A entrevista encontra-se transcrita no apêndice B) 
MEIRELLES, Rodrigo. Entrevista concedida ao autor. São Paulo, 30 de junho de 2016. (A entrevista encontra-se transcrita no apêndice B)

RONCONI, Carlos. Entrevista concedida ao autor. São Paulo, 16 de agosto de 2016. (A entrevista encontra-se transcrita no apêndice B) 
APÊNDICE A - Tabela pesquisas sobre o som na televisão

\begin{tabular}{|c|c|c|c|c|}
\hline ANO & TÍTULO & AUTOR & TIPO & ORIGEM \\
\hline 2014 & $\begin{array}{l}\text { Análise da trilha musical da } \\
\text { minissérie A Casa das Setes Mulheres }\end{array}$ & $\begin{array}{l}\text { Jefferson Tiago } \\
\text { de Souza } \\
\text { Mendes da Silva }\end{array}$ & Dissertação & UFMG \\
\hline 2013 & $\begin{array}{l}\text { Música, telenovela e periferia: o caso } \\
\text { da trilha sonora de Avenida Brasil }\end{array}$ & Felipe Trotta & Artigo & INTERCOM \\
\hline 2012 & $\begin{array}{c}\text { A música da minissérie brasileira no } \\
\text { exemplo de Anos Rebeldes }\end{array}$ & $\begin{array}{l}\text { Andre Checchia } \\
\text { Antonietti }\end{array}$ & Dissertação & UNICAMP \\
\hline 2012 & $\begin{array}{c}\text { Trilha sonora: da tv ao Youtube, } \\
\text { mediações narrativas na telenovela } \\
\text { Passione }\end{array}$ & $\begin{array}{l}\text { João Paulo } \\
\text { Fagundes Ledo }\end{array}$ & Dissertação & PUC-SP \\
\hline 2011 & $\begin{array}{l}\text { Na trilha das hierarquizações do } \\
\text { mercado musica: as relações entre as } \\
\text { telenovelas Globais e a indústria } \\
\text { fonográfica para a longevidade e } \\
\text { legitimação artística }\end{array}$ & $\begin{array}{l}\text { Heitor da Luz } \\
\text { Silva }\end{array}$ & Artigo & INTERCOM \\
\hline 2010 & $\begin{array}{c}\text { Som Livre: } \text { trilhas sonoras das } \\
\text { telenovelas e o processo de difusão da } \\
\text { música }\end{array}$ & $\begin{array}{l}\text { Heloísa Maria } \\
\text { dos Santos } \\
\text { Toledo }\end{array}$ & Tese & UNESP \\
\hline 2009 & $\begin{array}{c}\text { Trilha Sonora: o papel da música na } \\
\text { telenovela brasileira }\end{array}$ & $\begin{array}{l}\text { Debora Cristina } \\
\text { Lopez }\end{array}$ & Artigo & INTERCOM \\
\hline 2009 & $\begin{array}{l}\text { O som das desigualdades: reflexões } \\
\text { sobre a trilha sonora de Vidas Opostas }\end{array}$ & $\begin{array}{l}\text { Mariane Harumi } \\
\text { Murakami }\end{array}$ & Artigo & INTERCOM \\
\hline 2008 & $\begin{array}{l}\text { O estado de sizígio de televisão: por } \\
\text { uma metodologia de pesquisa do som } \\
\text { no audiovisual }\end{array}$ & Magda Rosi & Dissertação & UNISINOS \\
\hline 2005 & $\begin{array}{l}\text { A voz humana nas mídias sonoras: } \\
\text { uma análise da escuta e da emissão } \\
\text { vocal midiática }\end{array}$ & $\begin{array}{l}\text { Marcus Júlio } \\
\text { Sergl }\end{array}$ & Artigo & INTERCOM \\
\hline 2001 & $\begin{array}{l}\text { A trilha sonora da telenovela } \\
\text { brasileira : da criação à finalização. }\end{array}$ & $\begin{array}{l}\text { Rafael Roso } \\
\text { Righini }\end{array}$ & Tese & USP \\
\hline
\end{tabular}




\begin{tabular}{|c|c|c|c|c|}
\hline ANO & TÍTULO & AUTOR & TIPO & ORIGEM \\
\hline 1994 & $\begin{array}{c}\text { Som na telenovela : articulações som } \\
\text { e receptor. }\end{array}$ & $\begin{array}{c}\text { Fernando de } \\
\text { Jesus Giraldo- } \\
\text { Salinas }\end{array}$ & Tese & USP \\
\hline 1992 & $\begin{array}{c}\text { Propaganda : o dominio através do } \\
\text { Som: estudo da influência do som nos } \\
\text { comerciais de televisão. }\end{array}$ & $\begin{array}{c}\text { Marco Antonio } \\
\text { Batan }\end{array}$ & Tese & USP \\
\hline 1990 & $\begin{array}{c}\text { Contribuições da voz e da fala ao ator } \\
\text { de telenovela. }\end{array}$ & $\begin{array}{c}\text { Maria Helena } \\
\text { Kropf }\end{array}$ & Tese & USP \\
\hline 1988 & $\begin{array}{c}\text { Da dupla-dinâmica som-imagem uma } \\
\text { aproximação teórica ao som na } \\
\text { televisão }\end{array}$ & $\begin{array}{c}\text { Fernando de } \\
\text { Jesus Giraldo- } \\
\text { Salinas }\end{array}$ & Dissertação & USP \\
\hline
\end{tabular}




\section{APÊNDICE B - Entrevistas transcritas}

\section{Transcrição da entrevista realizada com Aroldo Barros, no dia 03 de agosto de 2016.}

\section{- Como foi sua passagem do rádio para a televisão?}

Entrei para a Rádio Tupi em 1973 e fui para a TV Globo em 1980. Convivi com a turma do radioteatro, mas não tive a honra de participar disso. Na Rádio Nacional, onde entrei em 1975 e fiquei até 1985, tive a honra de trabalhar com grandes nomes do rádio como Cesar de Alencar. Lá fui promovido de operador de áudio para sonoplasta. Dentre os inúmeros programas em que trabalhei, sem dúvida, o mais importante foi o Cidinha Livre, apresentado por Cidinha Campos. Mas não cheguei a trabalhar nas radionovelas.

- Como era o trabalho do sonoplasta no rádio e quais foram as mudanças quando você foi para a televisão?

Como já disse, na Rádio Nacional fui promovido a sonoplasta e isso acabou me projetando para a TV Globo através de um grande amigo que me convidou pra ir para lá. Na verdade, o que mudou foi que o que eu fazia no Rádio sem imagem, passei a fazer na TV com imagem. O trabalho em si, era o mesmo, com a diferença que agora eu estava trabalhando numa emissora que hoje é a $3^{\text {a }}$ maior do mundo e tudo que eu fiz lá foi pra mais de 160 países.

- Você poderia fornecer mais detalhes sobre o seu trabalho como sonoplasta nas telenovelas da TV Globo?

O sonoplasta sempre foi o responsável pelo produto final, sonorização e mixagem. Eu sou do tempo que o capítulo da telenovela saía da mão do sonoplasta e ia direto para o ar. Hoje em dia as coisas mudaram bastante. Quando comecei na TV Globo, no dia 02 de junho de 1980, não se falava em computador. Ninguém tinha nem em casa. Nós trabalhávamos mais ou menos assim: a telenovela era gravada, depois era editada e 
posteriormente ia para a sonorização. Quando chegava em minhas mãos, vinha somente com os diálogos, sem músicas e ruídos como, por exemplo, carro, cavalos, trovões, tiros e etc. Ou seja, tudo era adicionado na sonorização. Nessa época, nós utilizávamos discos de vinil (LP) e fitas de rolo. Para sonorizar um tiroteio, por exemplo, era um caos: imagina uma cena com vinte pessoas em uma troca de tiros. Inclusive, com alguns atirando ao mesmo tempo. A gente tinha que sincronizar aquilo já que o tiro que vinha da gravação da cena era de festim, às vezes nem isso. Dessa forma, nós criávamos mecanismos para fazer o sincronismo. Por exemplo, quando o determinado personagem piscar o olho nós soltamos o som do tiro que vai cair exatamente no tiro. Fazíamos coisas desse tipo assim e o pior é que funcionava. Quando chegou lá o primeiro computador eu sinceramente achava que aquilo ia me morder. (risadas) Naquela época era tudo feito muito artesanalmente. Hoje com a tecnologia as coisas mudaram muito e acabou um pouco da emoção. Basta apertar botões e a coisa vai fluindo.

- Existia um editor de diálogos, ou era o próprio editor de imagem que editava as vozes?

O editor não fazia isso e sim o sonoplasta. Na verdade, dávamos uma equalizada melhorando o que podia, na medida do possível, e de acordo com o pouco tempo que tínhamos para entregar o capítulo pronto para exibição!

- Você deu o exemplo da cena do tiroteio e a "loucura" que era sonorizar e sincronizar os sons. Hoje em dia, com nas plataformas digitais - como, por exemplo, o Pro Tools - você não tem limites de pistas e tem a possibilidade de colocar uma grande quantidade de sons ao mesmo tempo. Como era naquela época?

Muitas restrições! No lugar do Pro tools tínhamos uma máquina de rolo com oito canais, que na verdade podíamos usar seis, já que no oitavo era gravado o time code para sincronismo da máquina com o VT. Tudo que se gravava no canal sete era inutilizado pelo "zumbido" desse mesmo time code. Portanto, o canal sete não era utilizado. Dos seis canais restantes, dois eram destinados a captura do áudio que vinha do VT. Como era mono vinha o diálogo principal em um canal e no outro os áudios adicionais que o editor por alguma razão não podia mandar no principal. Sendo assim sobravam quatro canais pra gente brincar como se dizia na época, colocar ruídos e músicas. Ai entrava em cena a criatividade de cada um, 
vamos voltar ao tiroteio: fazíamos uma base com os principais tiros e quando os canais já estavam esgotados reduzíamos tudo para um determinado canal e liberávamos os restantes pra começar de novo. Depois fazíamos o mesmo processo até ficar pronto. Terminado o ruído tínhamos que colocar as músicas. Havia casos de se passar tudo que estava pronto para o VT e depois voltar pra fita novamente ocupando menos canais para ter como colocar as músicas. Enfim, “um verdadeiro samba do criolo doido!?. Temos até uma página no facebook com o título: Nós fizemos acontecer. É claro que fazer isso devia perder qualidade, com tantas cópias pra lá e pra cá, mas era o que tínhamos no momento.

\section{- Nessa época o sonoplasta trabalhava sozinho?}

Nós sempre trabalhávamos em dois: um sonoplasta de mixagem final, que era o meu caso; e outro de efeitos sonoros, que naquela época era chamado de "ruideiro". Ele era peça fundamental no auxílio da sonorização. Hoje é "um mundo" de pessoas envolvidas nesse mesmo trabalho que fazíamos em dois. Uma coisa que é usada até hoje é o que se usava nas radionovelas: um estúdio onde tem algumas caixas encravadas no piso contendo areia, pedra, mato e etc. Para que isso? Quando um personagem está cavalgando com duas metades de uma casca de coco se faz o som da pata do cavalo. Isso não tem tecnologia que de jeito. Vai ser sempre assim!

- Quanto tempo em média você tinha para fazer um capítulo de telenovela?

Não tinha um tempo estipulado, dependia muito da hora em que o editor entregava o capítulo para o sonoplasta. Muitas vezes tínhamos que sonorizar a "toque de caixa" para dar tempo de ser exibido. Fiz uma minissérie, Os Maias, que era sonorizada em blocos separados. Enquanto um bloco estava sendo exibido eu estava sonorizando outro. Quando eu terminava de sonorizar o último bloco, tinha um helicóptero com o motor ligado esperando no Projac para levar a fita para o Jardim Botânico para ser exibida. Isso aconteceu em todos os capítulos com raríssimas exceções. 
- Como eram os equipamentos de áudio na década de 1980 quando você entrou na TV Globo?

Os equipamentos eram muito arcaicos para os dias de hoje, mas muito modernos para aquela época. Nós usávamos gravadores de rolo e discos de vinil.

- Você comentou que hoje em dia as coisas mudaram muito. Você se refere à digitalização dos processos, o uso de computadores, softwares, entre outras coisas? Você se lembra de quando isso começou a acontecer? O que exatamente mudou no trabalho do sonoplasta?

Isso começou a acontecer com a chegada do primeiro computador, que citei na outra resposta que eu pensei que ia me morder. Foi no final dos anos 1990 se não me falha a memória e era o Audioframe, saudades! Acho que a tecnologia veio para ajudar e ajudou muito, mas também atrapalhou na medida em que hoje se cria tão pouco apenas apertando botões e fazendo tantas "firulas", que na maioria das vezes vira uma verdadeira "sopa de entulho". Ou seja, muita tecnologia e pouquíssima criatividade.

- Ainda no âmbito da tecnologia, quero lhe perguntar sobre a transição do som mono para o estéreo (em dois canais). Você se lembra de quando isso aconteceu nas telenovelas? Qual foi a primeira? Quais foram as mudanças que a transmissão em estéreo provocou no trabalho de sonoplastia?

Não me lembro a primeira e nem quando, porque fomos mudando muito gradativamente. Na minha opinião, o que mudou foi que passamos a ouvir um som muito mais claro e limpo uma sonoridade agradável aos ouvidos. Mas foi muito simples, apenas tivemos que adaptar músicas e ruídos de mono para estéreo e executar da melhor maneira possível. Foi muito bom, por exemplo, poder colocar a voz de um personagem que chama do lado direito do vídeo para que o personagem que está em cena olhe para a direita, ou um carro passando na cena literalmente passando se é que me faço entender?! O estéreo deu mais qualidade ao trabalho do sonoplasta, sem dúvida nenhuma. 
- No que diz respeito à produção dos ruídos na TV Globo, o Geraldo José foi uma figura central no desenvolvimento desse setor na emissora, correto?

Sim, o Geraldo José foi o professor de todos nós, principalmente em se tratando de ruídos. Sempre usei uma frase para tentar definir Geraldo José: É mais fácil perguntar ao Geraldo José qual o ruído que ele não tem, porque se perguntar qual ele tem, ele tem todos! Um verdadeiro "monstro sagrado" do rádio, teatro e televisão!

- Como funcionava o setor responsável pela criação da banda internacional da telenovela?

Como eles recebiam tudo mixado, eles refaziam tudo tentando manter a mesma linha criada por nós. As músicas, em sua grande maioria, eram substituídas devido à problemas com direitos autorais. Uma música do Elton John, por exemplo, que era exibida aqui no Brasil não poderia ser exibida nos 160 países. Então era trocada por outra ou gravada uma nova versão com algum outro artista. Creio que isso continua assim, apenas a maneira de fazer deve ter mudado um pouco já que com a tecnologia eles agora têm como receber tudo separadamente em cada canal de origem.

\section{Transcrição da entrevista realizada com Carlos Ronconi, no dia 16 de agosto de 2016.}

- Como eram os equipamentos e os processos da produção sonora da TV Globo na década de $1970 ?$

Na década de 1970 eu estava saindo do colégio, então eu não tinha experiência de televisão ainda. Eu comecei na TV Globo em 1988, então o que eu sei também é história, ou seja, vendo o que as pessoas faziam aqui, conversando com as pessoas que estavam aqui, vendo processos, analisando e comparando com produção lá fora. $\mathrm{O}$ áudio na televisão nasceu do rádio, ou seja, o rádio era uma coisa real no Brasil, existia e todo mundo conhecia. A televisão veio para preencher uma coisa de imagem, só que ninguém sabia como seria a imagem. Mas o áudio todo mundo já conhecia, já tinha uma estrutura de áudio que era do rádio. Então, a estrutura de áudio foi adaptada para trabalhar com televisão. Até hoje, a gente 
"sofre" com as funções dos cargos de áudio, são todos cargos que vieram do rádio. Por exemplo, ao invés de engenheiro de mixagem a gente tem sonoplasta, que é uma função de rádio. O sonoplasta é aquele "cara" que nas radionovelas colocava a trilha sonora, colocava os efeitos e tal. Fazia a sonoplastia, a "plastia" do som, a modelagem do som. A gente herdou inclusive a nomenclatura, veio tudo da rádio.

Então nas décadas de 1960 e 1970, no começo da televisão como indústria grande, você tinha essa adaptação vinda do rádio. As funções dos cargos eram bem parecidas, os equipamentos também eram bem parecidos. Com a diferença de que ao invés de você botar no ar direto, você gravava junto com a imagem. Então, você tinha um gravador de videotape, que nessa fase se chamava Quadruplex, que usava umas fitas grandes de 2 polegadas de largura. $\mathrm{O}$ áudio era gravado numa pista junto com isso, você tinha tudo numa mídia só. Ao contrário do cinema que você grava imagem na película e o som em outra mídia. Então, com isso alguns processo do cinema que eram benéficos para segurança foram esquecidos pela televisão, sincronismo por exemplo. Até agora que a gente tava no meio analógico, o sincronismo não era problema porque você gravava tudo na mesma fita. Ou seja, áudio e imagem estavam sempre juntos, não havia uma dissociação. Enquanto no cinema você tinha áudio gravado num gravador e a imagem gravada numa película, mesmo no meio digital esse processo ainda continua.

Por que eu digo que a gente perdeu alguma coisa? Porque, por exemplo, o processo de sincronismo que existe no cinema é muito mais eficiente se você considerar a rapidez de resposta, se comparado com a televisão. Preocupou-se em se fazer alguns procedimentos no cinema, por exemplo, a claquete para marcar um ponto de sincronismo na imagem e no som. Na televisão, não havia necessidade, porque já estava tudo junto. Então tecnicamente, um dos aspectos mais relevante de mudança que a gente teve é que o som e a imagem estavam sempre no mesmo componente, na mesma mídia, na fita. Isso perdurou toda a década de 1970, 80 e 90. Até o começou dos anos 2000 o VT era a principal mídia de armazenagem, então áudio e vídeo eram gravados juntos.

No caso da TV Globo, ela se aprimorou com relação às últimas décadas. A gente começou a ter um procedimento mais parecido com o cinema. Com a gravação de áudio separado do vídeo, você têm mais canais de áudio para poder trabalhar. Tudo isso evoluiu com a chegada do digital. Eu costumo dizer que a maior inovação que ocorreu em termos de áudio foi na década de 1970, com o desenvolvimento da amostragem do áudio digital. Você poder converter áudio analógico em bits. Isso eu acho que foi um grande passo no áudio. Não só na televisão, ou no cinema, mas no disco, na rádio, em tudo. Então, a grande virada do 
áudio aconteceu no meio da década de 1970 com a digitalização. Depois o resto foi consequência, o aprimoramento dos computadores, a amostragem 16 bits para 24 bits. Esse crescimento foi uma coisa que veio a reboque da digitalização, que foi a coisa mais importante que a gente teve.

Então década de 1970 e 1980 não houve muita diferença porque se gravava direto no videotape. Ou se você está falando de estúdio, por exemplo, os seus microfones vinham direto em uma mesa de mixagem e essa mesa de mixagem mandava o áudio direto para o VT. Seja ele Quadruplex, 1 polegada que veio depois, ou mesmo no formato Betacam e U-matic. Qualquer formato de fita que tenha acontecido, a gente pode considerar que tudo andava junto, imagem e som na mesma mídia. Então problemas de sincronismo raramente existiam. Salvo quando você fazia um broadcast ao vivo via satélite, que você podia ter sinais e caminhos separados via satélite, ou via terrestre, ai você podia ter problema de sincronia. Mas até então, sincronismo nunca foi uma questão muito grave para a dramaturgia, para a novela. Tudo era gravado numa mídia só.

Com relação aos equipamentos, no começo o que se usava em rádio foi aproveitado em televisão. Então as mesas de broadcasting vieram do rádio para a televisão. Aos poucos elas foram se modernizando para trabalhar com televisão. Como tudo era analógico não havia necessidade de você sincronizar nada, as mesas de som do rádio funcionaram bem na televisão até muito pouco tempo atrás. Com a necessidade de se ter mais recursos equalização, compressão, coisa que na mesa de rádio não é muito necessário - algumas mesas mais dedicadas que vieram dos estúdios de gravação de música foram sendo adaptadas para trabalhar com a televisão. Em televisão, você usa poucas entradas, um estúdio de gravação de telenovela, por exemplo, você trabalha no máximo com quatro a seis microfones. Considerando década de 1970 e 1980, você tinha dois ou três microfones no máximo que, normalmente, eram boom. Hoje em dia não, porque a gente trabalha num formato bem parecido com o cinema, com microfones de lapela individuais para cada artista e mais o boom para pegar o geral da cena. Isso requer que você grave mais canais do que antigamente. Então quando a gente fala de década de 1970 e 1980, a gente fala em um ou dois canais de som na fita. Hoje a gente fala acima de oito canais gravados em uma mídia separada, uma mídia digital separada. Essa foi a grande mudança.

Os microfones não mudaram muito. Hoje em dia se você pegar um microfone mono direcional - que é o que a gente usa para gravar novela - ele têm basicamente o mesmo desenho da década de 1970 e 1980. Claro, o que melhorou foi a eletrônica em si, mas o conceito é o mesmo: microfone direcional capacitivo de longo alcance. O peso foi 
diminuindo, o que ajuda o operador de áudio a carregar aquele "negócio" lá em cima. Então o que houve foi uma evolução do mesmo princípio, nenhum salto mirabolante com relação à captação.

Quando a gente começa a falar em captação em estéreo - por volta da década de 1990 quando o Brasil começou a entrar em estéreo - o diálogo não muda muito. A gente continua captando em mono, porque a referência é o centro da tela, o diálogo é em mono. Mas a sua ambientação começa a mudar, você começa a captar efeitos e ambientes em estéreo. Por exemplo, você vai gravar em um supermercado ou em uma praça, você capta os ambientes da praça em estéreo ou em 5.1. Na TV Globo, hoje em dia todas nas novelas a gente faz em 5.1, com o ambiente em surround. Então, você tem toda essa captação não simultânea, ou seja, não na mesma hora que eu estou gravando a cena eu estou gravando ambiente, porque tem interferência. Normalmente a gente volta no mesmo lugar e grava o ambiente daquele lugar separado no outro dia, mais ou menos nas mesmas condições para gente criar aquela atmosfera, o room tone, aquela ambientação toda.

Na década de 1970, não se tinha muito tempo para fazer isso, até porque não havia um aprimoramento de pós-produção. Então em termos de captação quase nada mudou, no sentido do procedimento, mudou obviamente a qualidade dos equipamentos. $\mathrm{O}$ tipo de equipamentos que são usados, o tamanho e a portabilidade. Se você pensar que na década de 1970 uma câmera era quase que impossível sair do estúdio pelo tamanho, na década de 1950, 60 e 70 você tem pouca cena de externa. Você tem cena de externa rodada com câmera de cinema, rodada com 35mm, ou 16mm. Como o jornalismo foi por um bom tempo. Só no começo da década de 1970 que o jornalismo passou a usar câmeras portáteis para fazer matérias e tudo mais.

\section{- Como era a captação de som em ambientes externos e nas cidades cenográficas?}

Elas eram todas gravadas com unidade móvel, ou seja, era um ônibus com as câmeras todas juntas. Você não tinha uma unidade portátil de gravação como você tem hoje câmeras portáteis. Você tinha uma unidade móvel, que era um ônibus que se deslocava para os lugares, estacionava, ligava o gerador e dentro você tinha uma pequena central técnica com as câmeras todas ligadas por cabos. Como se fosse um estúdio móvel. As cenas externas eram gravadas assim. Raramente você tinha uma cena gravada em película, que depois era telecinado com a 
imagem editada junto. Quando você precisava de um sistema extremamente portátil você apelava para isso.

Assim, em termos de captação a evolução que houve foi a evolução de equipamentos, uma evolução de tecnologia simplesmente. Os procedimentos ficaram basicamente padrões até aproximadamente a década de 1990. Quando você começa a trabalhar em estéreo a captação continua mono, porque o diálogo a referência é sempre o centro da tela. Então justifica você captar um diálogo estéreo?! Não, porque você não sabe como o editor vai trabalhar com aquilo. Então se você estiver captando um diálogo estéreo, na perspectiva da câmera, um cara na esquerda e um na direita, você pode fazer outro take depois com um enquadramento central, por exemplo: abre a cena com um personagem de cada lado, ai fecha na fala de um personagem, se você continuar captando estéreo aquilo vai ficar esquisito, porque vou ver o personagem no centro e o som dele saindo de um lado. Então é sempre preferível captar tudo em mono e na pós-produção a gente constrói se precisar. Se você considerar que a maioria das televisões ainda é analógica, ou formato 4:3, é muito pouco provável que você brinque muito com essa coisa de separação na tela. Porque a perspectiva de ponto de vista do telespectador, ou seja, a distância que ele senta da tela, a abertura do estéreo para ele na televisão não justifica você brincar assim. Muito mais central (os diálogos). A não ser que seja para um público que tenha um maior poder aquisitivo que tenha uma flat screen, uma TV HD e tudo mais, ai você vê que aproveita melhor o panorama estéreo. Não falo nem do 5.1, porque acho que a porcentagem (de pessoas) que hoje em dia senta na frente da televisão para assistir alguma coisa em 5.1 - que não seja DVD e tal -, novela ou qualquer outra coisa, é muito pequena. Mas mesmo assim a gente faz, porque a gente acredita que há um mercado bom para isso, fora do Brasil também. E é um exercício para a gente, fazer toda essa dramaturgia complicada em 5.1, é um exercício bom.

- Atualmente há tempo para fazer duas mixagens: estéreo em dois canais e em 5.1?

Depende muito do "approach", normalmente para uma minissérie a gente faz dois mix. Uma novela normalmente você faz um downmix. Na minissérie você tem tempo, então você consegue fazer uma mixagem em estéreo (em dois canais) e outra 5.1 e comparar as duas. No downmix muitas vezes você consegue ter uma percepção boa do estéreo, normalmente você não tem cenas mirabolantes em novelas, cenas que existam uma "pirueta" de áudio. Então você tem basicamente uma ambientação no 5.1, você tem uma cena gravada numa praça, ou 
numa floresta, então você tem o ambiente no 5.1 e alguns ruídos pertinentes. Você sabe que têm uma casa, um vozerio atrás se você está de costas para alguém, então você pode colocar isso atrás. Mas quando você faz o downmix isso não prejudica tanto. Então depende muito do sonoplasta e o tempo que o cara tem para fazer. Mas praticamente todas as novelas da TV Globo são feitas em 5.1. Mas isso na pós-produção tá, quer dizer, a gente sai da captação para ir para a pós-produção, toda essa parte de multicanal ele é feita na pós-produção.

Existia um padrão de transmissão de áudio para a televisão aberta antes da implantação da legislação de Loudness?

Não, antes da lei cada um usava o seu "approach”. A TV Globo ela sempre foi crítica com relação a isso e a gente sempre tentou seguir alguma recomendação da $L B U$, ou da $I P U$. Com relação a níveis nunca houve nada regulamentado, tanto que toda a televisão teve que se adaptar para o formato do Loudness. Mas a gente sempre trabalhou com uma margem de pico dentro do que era aceitável. Porque você tem que considerar vários aspectos quando a gente fala disso daí. Você tem uma programação variada, então você têm vários tipos de programas durante o dia. Você tem de manhã lá um programa de entrevista que tem uma variação dinâmica $X$, você tem lá no meio do dia o jornalismo, que basicamente é informação falada texto falado que é a compreensão da fala do que está sendo dito ali - e você tem no final do dia os shows, o prime time, os programas de maior qualidade. Cada um tem o seu range dinâmico, a preocupação com o jornalismo é você priorizar a voz. A voz tem um range dinâmico muito pequeno, então você não precisa deixar muito headroom para cima para trabalhar, você coloca um compressor e "crava" aquilo ali na faixa que as pessoas possam entender sem ter que ficar mexendo no volume. Ou seja, tudo que acontecer, tem que acontecer em volta da voz. Quando você vai para a novela, por exemplo, você tem um range dinâmico um pouco maior, porque você tem músicas e efeitos. Então, a tua voz continua ali e você têm que abrir um pouco mais o range dinâmico para que as pessoas consigam perceber as diferenças entre sussurro, grito, um carro passando, o "cara" gritando, um tiro acontecendo, coisas desse tipo. A medida que você avança na noite o que acontece?! Você tem que começar a controlar esse range dinâmico, se você colocar uma explosão muito mais alta que é o nível de voz - que na realidade é o que acontece - você vai obrigar o cara a ficar mudando no controle o volume sempre para baixo, ou seja, o cara entrou numa boate tá a música tocando lá num nível legal, ai o cara começa a falar muito baixo, então você têm que 
aumentar o volume para entender o que o cara tá falando. Essa variação é prejudicial, porque o telespectador não vai ficar mudando o volume. Isso é igual a um engarrafamento que você fica mudando a marcha, muita gente colaca primeira e fica, porque é um "saco" ficar colocando segunda, depois volta para a primeira, depois volta para a segunda... Então com o volume eu comparo que é mais ou menos assim. As pessoas de repente começam a reclamar que está muito baixa a voz, por que?! Porque elas têm que ficar aumentando e abaixando para compensar o resto. Então o ideal é que para esses programas que vão tarde da noite que você comece a trabalhar com o range dinâmico menor, porque é o que acontece na vida real, você está num ambiente mais silencioso, no próprio ambiente da sua casa, você está numa posição mais calma de maneira que a variação dinâmica é bem menor. Se a televisão estiver ali perturbando você vai começar a reclamar, porque você vai sentar para ouvir a fala e de repente vem uma música alta e você abaixa, ai quando o "cara" volta a falar, a fala está baixa e você aumenta de novo. Então, hoje a gente sempre tenta trabalhar nesses programas depois do prime time - 23 horas, meia noite - com uma variação de range dinâmico menor. Se você pegar qualquer receiver de som 5.1 têm lá o night mode, ou compress mode, cada um funciona de um jeito, mas é exatamente para diminuir o range dinâmico para você continuar percebendo tudo sem ter que ficar aumentando e baixando volume.

As transmissões das telenovelas via internet seguem os mesmos parâmetros de áudio da TV Digital?

Basicamente segue o mesmo parâmetro. Na realidade, a gente tem até um meio mais “perdoável”, vamos dizer assim, do que a própria legislação de Loudness, você poderia usar um range maior. $\mathrm{O}$ que você tem que levar em consideração é o seguinte, nem todo mundo houve num dispositivo - computador ou dispositivo móvel - de uma maneira ideal. O que seria ideal? "Ah eu vou ouvir no meu tablet com o meu fone!" Assim você vai escutar com as limitações do áudio comprimido que, normalmente, é um $A A C$ comprimido assim como é para a televisão. O $A A C$ você tem compressão sem perda, então você têm qualidade. Mas se o "cara" for ouvir direto na caixinha do computador, ou no próprio alto-falante do telefone ou tablet, ele não tem a mesma qualidade. São coisas que não foram feita para ouvir assim, servem apenas como referência. Então o ideal é que o "cara" ouça em um fone de ouvido, se for ouvir com o fone não tem problema nenhum, ele vai ter a mesma sensação que ele vai ter 
ouvindo na TV aberta. Os softwares que a gente utiliza, os codecs de internet, eles fazem com que o áudio passe transparente.

\section{Transcrição da entrevista realizada com Guerra Peixe Filho, no dia 16 de dezembro de 2016.}

- Como era a captação de som direto nas décadas de 1960 e 1970?

Geralmente eles gravam direto com um microfone operado pelo boom man. Hoje em dia está bem melhor, os microfones estão bem melhores, mas naquele tempo já tinha um microfone "pontiagudo" que captava o som direto. Agora quando acontecia alguma coisa, quando gravava no mar, aquele barulho do mar e a voz do ator não saia legal, ai recorria à dublagem. Mas na maioria das vezes na externa e estúdio era sempre som direto.

- Nessa época utilizava-se microfone de lapela?

Não, não tinha. Às vezes tinha, mas era tudo com fio. Naquela época, não tinha nenhum microfone sem fio, era tudo com fio. Nos jornais, o apresentador Luís Jatobá tinha um microfone que ficava em uma "mesinha" e tinha um cordão, ou então colocava uma fita e prendia na gravata. Os outros que ficavam em uma bancada, com bancos, era um boom no alto e o operador já sabia mais ou menos quem ia falar. Então levava para aquele, trazia para o primeiro, corria com aquele boom. Só tinha dois microfones, o Luís Jatobá, que era o principal, e os outros era um boom que corria de acordo com quem estava falando. Mas hoje em dia é quase tudo sem fio, hoje em dia quase todo mundo usa aquele "aparelhinho" nas costas e fica com o sem fio.

- Mas e nas telenovelas era comum o uso de microfones de lapela?

Muito difícil usar o lapela. Inclusive, às vezes escondia os microfones atrás de um abajur, quando tinha um diálogo mais longo, ou tinha um ator muito perto do outro. Colocava 
um microfone escondido atrás de um abajur ou alguma coisa assim e o outro com o boom man.

- Citando o depoimento de Daniel Filho sobre a inserção das músicas e ruídos no momento da realização da cena na época de Irmãos Coragem.

Muito difícil, só se não tivesse diálogo. Se tivesse diálogo não tinha como colocar a música direta no estúdio. A música é sempre colocada depois. Era muito difícil, só se fosse uma dança que ninguém ia falar, podia botar o som no estúdio. Mas às vezes servia só de guia, que depois tirava e colocava outra. Porque o som do estúdio não é igual ao som que você coloca depois, colocar o som no estúdio vai sair na caixa de som.

- Como era o processo de sonoplastia nas décadas de 1960 e 1970?

Você pegava a fita de VT e passava aquele áudio "todinho" para um canal, só tinha dois canais, passava para o canal de baixo já acrescentando música e ruído, depois voltava tudo para o canal de cima de novo já completando com o que estivesse faltando. Porque às vezes não dá para você emendar uma música na outra. Então passava para o canal debaixo e colocava algumas músicas, quando voltava para o canal de cima acrescentava outras músicas e ruídos. Naquele tempo era assim, hoje em dia não. Hoje em dia, a gente já tinha essa Studer de oito canais, tudo mais moderno. Antigamente, para a gente acertar um tiro você levava 2 horas, o tiro estava em uma fita você ficava apertando o botão e não acertava o tiro de jeito nenhum. Hoje em dia não, hoje em dia o "cara" marca lá aos 2 minutos, 30 segundos e 2 frames e colocar lá o tiro que vai sair certinho. Antigamente, você tinha que fazer isso tudo no dedo. Era fita de áudio com o tiro gravado e para você acertar o tiro na hora certa você ficava até nervoso, pedia até para outra pessoa fazer, porque você não acertava. Quando era tiroteio era coisa de maluco. 
- Então não havia gravador de som externo na década de 1960?

Na década de 1960, quando começou, não tinha gravador (de som) de dois canais não. A própria fita do VT tinham dois canais. A gente usava o canal um, então você passava do canal um para a pista de cue. Naquele tempo não era canal dois, Cue era onde você marcava para trocar de cena. Então, a gente passava o áudio, que era o principal, do canal um para a pista de cue, acrescentando algumas músicas e ruídos. Depois voltava a pista de cue toda de volta para o canal um, que era o canal que valia, acrescentando o resto que ficou faltando quando você passou a primeira vez. Era na própria fita de VT, depois é que apareceram os gravadores externos, que tinham quatro ou oito pistas. Ai já é no final de 1980, eu não lembro bem.

\section{- Como era o armazenamento das músicas e ruídos?}

Tinha cartucho, que foi a primeira coisa que apareceu em rádio sem ser o gravador de rolo. O resto tudo era na base do disco. Naquele tempo se gravava o próprio disco. Era o acetato, você gravava, por exemplo, tem um tiro então você passava para o acetato, se não toda hora você tinha que pegar um revolver para dar um tiro. Então gravava tudo no acetato, que é igual ao LP, só que você grava ali tudo o que vai usar durante as novelas, os ruídos. Depois que veio a fita de áudio.

\section{- Você trabalhou com Geraldo José na TV Globo?}

Ele já vinha comigo, eu trabalhei com ele desde a Rádio Tupi. Ele foi fundador lá na Globo, ele entrou lá em 1965, quando a TV Globo foi fundada.

- Qual a importância dele para o desenvolvimento do setor de ruídos dentro da TV Globo?

Ele era o "rei do ruído". Hoje em dia está tudo mais moderno, né?! Você tem CD’s com todos os tipos de ruído, naquele tempo não era tão fácil assim, muita coisa você tinha que fazer. Hoje em dia não, tem CD's que vêm de fora que tem todo tipo de tiro, ruído de 
pássaros, cachorros, gatos, tudo o que você possa imaginar tem nesses CD’s. Eu mesmo deixei lá TV Globo quando eu sai, porque naquele tempo não tinha celular, então eu gravei aqueles tons todos de celular. Não pode usar aquela voz da mulher no ar, igual no aeroporto, porque cobram diretos autorais. Então eu gravava só os toques do celular.

- Sobre o processo que Geraldo José usava.

Ele tinha tudo em fita, ele mesmo fazia. Ele tinha um gravador Nagra portátil que ele levava para onde ele queria, ele mesmo gravava os ruídos dele. Ele ia na mata, no mar, ele tinha um repertório tremendo de ruídos.

- Sobre a banda internacional para as telenovelas, você poderia fornecer detalhes desse processo?

Era feito todo o trabalho, tinha que fazer tudo, os ruídos todos, até os passos. Porque tirava a voz toda, neh!? (...) Então, fazia uma trilha só de ruídos e outra só de música. Para eles colocarem a voz.

- O trabalho com os ruídos e as músicas das trilhas internacionais é diferente do que é realizado para a trilha original que é transmitida no Brasil?

Tinha que fazer tudo de novo. Porque no momento que eles iam colocar a voz, acabavam todos os ruídos que estavam "embaixo". Então no momento que eles iam colocar a voz lá - em francês, italiano, etc - tinha que ter a parte de ruído todinha junto e as músicas também.

- Então a trilha sonora exportada é diferente da trilha sonora nacional?

Sim, não é nenhum de nós que faz isso. Têm lá o Departamento Internacional que têm os sonoplastas próprios, é tudo separado. Eles pegam a novela e tem que fazer tudo de novo, 
os ruídos... Mas não é nenhum de nós. Inclusive o Departamento Internacional fica no Jardim Botânico e o nosso no Projac.

\section{Transcrição da entrevista realizada com Rodrigo Meirelles, no dia 30 de junho de 2016.}

\section{- Você poderia fornecer um panorama da evolução da produção sonora na TV Globo?}

Uma coisa que eu vejo bem clara de construção sonora em televisão é que ela vem de um legado bem diferente do cinema. A TV tem uma história bem peculiar na construção de som, vêm da questão do sonoplasta. Hoje você não encontra muitos sonoplastas no mercado de cinema, não se fala em sonoplasta em cinema, no nacional mesmo. Então você tem o artista de foley, você tem o editor de som, você fala muito em cinema na figura do editor de som. É o mesmo nome da escola hollywoodiana, cinema internacional como um todo. É a pessoa que edita o som e mixa também. Lá fora, você tem o re-recording engineering que é o engenheiro de regravação, que vai passar para mídia final todo o material mixado. Existem várias funções técnicas que em TV se fala muito do sonoplasta. Até hoje você tem, até por questões talvez de RH e sindicatos, a função do sonoplasta presente na televisão. É até um cargo que parece desatualizado, as pessoas que não estão muito por dentro de como se dão os cargos em televisão falam: "Pô, vocês ainda tem sonoplastas?!" Não é ainda, sempre foi o nome do cargo do profissional que trabalha com som em finalização e no ao vivo também. Mas cinema não, você não vê um sonoplasta em cinema. Pode ver um cara que foi sonoplasta em televisão indo trabalhar em cinema e se intitulando sonoplasta, mas como cargo dificilmente você tem o sonoplasta em cinema. Embora, hoje em dia, eles façam a mesma coisa na prática e trabalhem com as mesmas ferramentas tecnológicas, como o Pro Tools, etc.

Mas por que isso? A televisão vem de uma época que o papel do sonoplasta era apoiar a edição de imagem colocando música, então por muito tempo o trabalho principal do sonoplasta foi colocar música. Uma pessoa ou duas ali envolvidas no projeto em que o grande desafio - até porque a tecnologia limitava muito o processo criativo - era conseguir colocar em sincronismo uma música no melhor ponto. Então, o sonoplasta habilidoso e reconhecido artisticamente era aquele que conseguia com aquelas ferramentas do meio analógico colocar uma música para ela caber na cena, conseguir que o final daquela música com o final da cena, e que no início casasse direito. Coisa que hoje em dia com um ou dois cortes em um software 
você consegue resolver rápido. Até o montador, editor de imagem consegue fazer isso, no processo atual. Era o grande desafio do sonoplasta! Depois é claro, toda a parte de ambientação começou aparecer e como a mídia final não nos dava recurso, digamos assim como telespectador, para perceber nuances de áudio - transmissão analógica tinha muito chiado, os próprios aparelhos - era basicamente diálogo e música que você conseguia fazer para aquela mídia final. Diálogo e música e um pouquinho de ambiente. E as referências em cinema também eram bem ruidosas, o distanciamento da qualidade de som do cinema internacional e nacional era muito "gigante". Em televisão era aquele segundo nível ali de qualidade. Assim: "têm o som de cinema e o som de TV". Completamente diferentes em termos de qualidade, sendo o cinema melhor que a TV. Então o papel do sonoplasta era colocar música, ambientes em geral bem superficialmente. Tratamento de diálogos, não se falava nisso! Não existia ferramenta para isso! O som do diálogo era o que era captado, colocava música em cima e vai pro ar. Volume no máximo era o que se fazia em termos de mixagem. Um trabalho tecnicamente muito limitado por causa das ferramentas e artisticamente muito rico, porque com o pouco que você tinha conseguir fazer desenhos de som era incrível!

Eu uso muito como exemplo o caso de Roque Santeiro, que é do sonoplasta Aroldo Barros, que foi da minha equipe e eu até brincava com ele que era um dos primeiros sound designers em televisão, no sentido da palavra mesmo de desenho de som. Porque a pulseira em Roque Santeiro, aquelas acentuações que iam além de colocar uma música no fundo, ele começou com isso, ou pelo menos ele que começou a ser reconhecido por isso. Então é um trabalho de desenho de som, você colocar uma cascavel na hora que o "cara" vira a pulseira. Com aquilo que a gente tinha na época era o que dava pra fazer e ele fazia primorosamente. Porque marcava o telespectador, o som ajudando na narrativa, de forma limitada tecnicamente, mas de forma muito rica artisticamente.

No desenvolver da tecnologia com os sistemas não lineares, com o computador, a gente teve duas viradas muito grandes tecnológicas: a primeira você sair da fita analógica pra sistemas com apoio de computador, sistemas não lineares. O "primeirão" mais da minha geração - porque eu não peguei os anos 1970 e 1980 - foi o Solutions, que é um software que você tem a possibilidade de editar não linearmente o áudio, então mudou já. A gente conseguia nessa época editar diálogos, tirar ruídos. Caso viesse um ruído na captação você conseguia limpar, então esse tipo de coisa começou a aparecer, um trabalho bem técnico, muito mais técnico do que artístico. E depois o Pro Tools, o Pro Tools veio no mercado de pós-produção como uma virada tecnológica até para Hollywood. Não me lembro de qual foi o 
nome, mas ele ganhou o Oscar técnico por mudar o mercado de cinema, o mercado de som e cinema. A Digidesign que era a empresa fabricante de Pro Tools na época. Então, com esse acontecimento, o que o Pro Tools fez? Ele foi capaz de ser uma estação não linear que não só o som fosse "editável" e reproduzido em disco rígido, mas também que o processamento acontecesse em tempo real, ou seja, não era mais preciso você ter mesas de som, ou consoles digitais caríssimos e milionários para conseguir fazer um som, você precisa de uma placa de áudio e um bom computador.

Então o Pro Tools foi essa grande virada tecnológica, que na televisão teve um impacto muito grande. Aqui na TV Globo também! Porque você sai de pouquíssimos canais que você conseguia trabalhar para vários canais, isso mexeu em processos também. A gente passou de 2000 e pouco para cá a trabalhar com três, quatro pessoas envolvidas em um único projeto de dramaturgia, na pós-produção, ou seja, então não era mais uma pessoa pra fazer tudo, é uma pessoa pra fazer diálogos, outra para fazer efeito de ambientes e outra só para fazer música e a mixagem final, e o artista de foley. Normalmente, são quatro pessoas envolvidas num projeto. Por quê? Integração em rede, o mesmo sistema, todo mundo usando o Pro Tools, cada um podendo compartilhar arquivos: um fazendo uma sessão com 32 canais de efeito, que na mixagem final se junta com os canais de música. Então esse mundo digital de workstation, no caso do Pro Tools, viabilizou processos aumentados. Em cinema já era assim, você tinha que ter um cara dedicado para cada área, então os fluxos de trabalho ficaram muito próximos, tanto cinema quanto televisão.

- Antes do processo de digitalização como era a da pós-produção de som?

O trabalho de sonoplastia era esse: você incluía música, colocava um efeito, colocava uma acentuação, esse desenho sonoro era feito em pós-produção. Foi com próprio processo de pós-produção que a gente conseguiu fazer coisas que não dava pra gente fazer antes. Então começou a se aproximar da narrativa cinematográfica. Quando você pensa num projeto hoje de produção que você tem uma pessoa envolvida desde o inicio, que é o caso da minha equipe nova, por exemplo, hoje eu cuido dos produtores de áudio - que é um cargo meio que exclusivo aqui, que não tem em muitos lugares - que é uma pessoa que acompanha desde a pré-produção até o final. Então hoje você é capaz de pensar não só em captação, mas você consegue pensar no desenho sonoro meses de antecedência ao dia da gravação. Que não adiantaria nada há muito tempo atrás, porque você não ia conseguir inserir isso de forma 
inelegível para o telespectador. Hoje, a gente planeja, por exemplo: “ah, vai fazer a gravação na Amazônia”. Então a gente vai com uma equipe só pra fazer captação de ambientes, para serem aqueles ambientes específicos. "Ah, hoje a gente tem uma cena de computação gráfica" Então a gente vê a cena como ela vai ser e planeja as gravações reais que seriam daquele ambiente. A gente faz planejamento de sound designer, então a gente também tem estúdio de foley que a gente pode gravar em sincronismo com a imagem, sons específicos daquela cena, em vários canais para serem mixados depois. A gente pode identificar num processo de gravação que uma cena não valeu e pedir para substituir os sons na pós-produção. Ou, até mesmo, ver o material bruto dessa cena numa mídia que eu possa abrir em qualquer lugar, uma HD, ou um sistema em rede e identificar que naquela cena eu posso usar determinada ferramenta, determinado software, plugins para salvar. Prever isso antes da cena ser montada, então a tecnologia ajudou muito para a gente antever determinados problemas. Principalmente antever artisticamente o que a gente pode fazer de desenho sonoro. Então por isso que faz sentido hoje ter uma pessoa dedicada só para criação de efeitos. Por mim, se for pensar não só artisticamente, mas, sem pensar na questão de verba, poderia ter: uma pessoa fazendo só efeito, uma pessoa fazendo só ambientes, uma pessoa só editando o foley, uma editando os diálogos e outra gravando foley e outra realizando foley, uma pessoa só editando música e uma pessoa só mixando, às vezes uma pessoa fazendo a versão 5.1 e outra fazendo a versão em estéreo. Então você vai aumentando a quantidade de equipe, não é o caso ainda, mas a gente têm funções que hoje fazem sentido por causa da tecnologia, que antes não faziam sentido existir.

- Você poderia dar mais detalhes dos equipamentos analógicos utilizados na sonoplastia?

Nessa época não tinha recursos e nem tempo para fazer qualquer intervenção em pósprodução. Era basicamente colocar uma música e ver a questão de volume e nível técnico. Então até pelo tempo mesmo, a edição demorava mais porque você tinha mais trabalho, fitas, você não tinha tantos processos na pós-produção, capacidade e estrutura para fazer. O próprio trabalho que a gente fez na "As Cariocas", que é uma série do Daniel Filho, de ir para cada bairro do Rio de Janeiro e gravar os ambientes daqueles bairros - esse foi um trabalho bem preliminar, porque a gente tava começando com a questão do 5.1 - não seria possível em outros tempos. Porque onde a gente iria inserir isso!? Em quantos canais a gente iria inserir esse material!? A gente iria colocar isso no ar com uma "ruideira" no fundo dos chiados 
analógicos e o telespectador ia perceber essa ambientação dentro e fora dos lugares!? O cara que mora em determinado bairro ia reconhecer os sons do bairro, mesmo que subjetivamente, não conscientemente? Não, não faria sentido! Depois desse tempo, isso foi 2010, ai sim faria sentido! Então algumas coisas não aconteciam por não fazer sentido e não ter estrutura que fosse suficiente.

- Como era a captação do som direto no passado? Em externas eram usados equipamentos portáteis?

Equipamento portátil em externa sempre foi uma realidade. A questão é que o porte desses equipamentos obviamente era maior, eles eram em fitas, então era mais difícil de você fazer captação em externa. Em estúdios também, com a tecnologia analógica você ficava preso no processo linear de fita também. Mesmo ela sendo digital, o tempo de cópia é em tempo real que e diferente de um arquivo. Mas o que eu vejo como a grande virada de captação foi a gente passar a trabalhar com multicanal. Porque com o multicanal você consegue numa etapa de pós-produção trabalhar isoladamente lapelas, boom, microfones que você usou como "escória", que seria o microfone que o pessoal chama lá fora de planted mic, que é um microfone plantado em algum ponto do set, um lugar estratégico. Isso ajudou muito na qualidade, porque a mixagem que você faz no set de gravação, por melhor que ela seja, o operador está fazendo de fone e numa condição geralmente não muito adequada, pelo ruído externo e todos outros problemas que você têm que resolver ali no set de gravação. Então aquela mixagem dificilmente vai ser melhor do que receber todos aqueles microfones gravados separadamente e trabalhar numa ilha de pós-produção com calma.

Então independentemente da plataforma, eu acho que uma grande virada em termos de qualidade foi trabalhar com múltiplos canais. Isso realmente faz toda diferença. Por mais que você tivesse trabalhando com múltiplos canais, colocando lapelas em cada ator, boom e mais microfones espalhados pelo set, por mais que você tenha todos esses microfones, se você entrega para uma etapa de finalização só um canal, uma mixagem de todos esses microfones, fica preso a isso. Então a mixagem que você fez no set vai ser a mixagem até o final. Se um ator ficou baixo, ou você poderia ter valorizado o boom naquela cena ao invés de valorizar o lapela, coisas desse tipo, você não pode desfazer e refazer.

É claro que os gravadores evoluíram, os microfones evoluíram, os processos evoluíram. Hoje a gente tem a figura do produtor de áudio planejando as cenas, alguém fora 
dos sets, a gente dialoga muito mais hoje, assim nos últimos dois anos. Inclusive, a gente teve um projeto aqui chamado "Plano de áudio", ele internamente vem gerando várias mudanças, principalmente nos diretores artísticos, no ar a gente vêm tendo muito menos reclamações. Enfim, a gente dialogando mais com as outras áreas e tendo pessoas cuidando dos projetos sem necessariamente estar ali operando - transitando em diversas frentes, externa, estúdio, pós-produção, isso vêm ajudando muito! Então pensar o processo de áudio tem sido uma coisa que vêm impactando na melhoria de qualidade.

- Era comum utilizar lapelas e boom ao mesmo tempo como hoje em dia?

Possível era. Eu só não sei, porque eu não estava aqui na época, se era uma prática recorrente usar o lapela na gravação analógica. O que eu posso te dizer é que lapela sempre foi uma realidade, só que existem correntes de época em época. Tem época que vêm do próprio artístico: “Ah, vamos priorizar o boom!". Ou têm épocas que: "Não! Eu gosto de trabalhar só com o lapela!” Enfim, na minha opinião como profissional de áudio é que a gente tem que trabalhar com os dois. As ferramentas estão ai para serem usadas, ai na pós-produção a gente recorre a um ou outro dependendo do caso. Os microfones aéreos são a prioridade de quem trabalha com áudio, porque a gente sabe da característica do som deles: o quanto a gente consegue, dependendo do posicionamento, a sonoridade mais adequada; a gente tem o controle de acordo com o microfone que a gente escolhe para a cena, o quanto a gente vai captar de direcionalidade, a gente pode ter um microfone mais direcional ou menos direcional; a gente consegue ter mais daquele ambiente, mais perspectivas sonoras, espacialidades. Então o microfone aéreo é sempre o que a gente prioriza, mas isso não quer dizer que trabalhando com o boom a gente não vai usar o lapela. O lapela é uma grande ferramenta pra gente nos planos mais abertos, ou até mesmo para pegar o melhor som daquele ator quando a gente tem algum problema com o microfone aéreo.

- Perguntei se, de modo geral, então a preferência é pela utilização do boom.

Depende muito, mas priorizar o boom, porque geralmente é o que nos dá as perspectivas de áudio, que nos dá os planos sonoros que a gente quer nos sets: longe, perto, um pouco de espacialidade, a gente consegue gravar com um timbre mais natural. O lapela 
não! Não importa qual o movimento do ator (...) têm a questão do figurino, sempre vêm o risco de raspar (...) então o lapela está ai como nossa segurança e às vezes têm até o melhor som. Mas normalmente a gente prioriza o boom, essa é uma prática tanto em cinema quanto em televisão. A gente de som sempre espera que o melhor som venha do microfone aéreo. Mas tem cena que é impossível, então a gente sabe que o melhor som vai vir do lapela.

Hoje o tipo de produção de telenovela e de séries de televisão é muito próxima da discussão do cinema. Tecnicamente é a mesma discussão. Hoje eu tenho discussões, fóruns e debates com o pessoal de cinema e são os mesmos problemas. A gente vai até para encontros de áudio e discutimos exatamente os mesmo problemas, os mesmos equipamentos, as mesmas técnicas. A única coisa que muda é tempo, processos e a narrativa, que vai ser diferente em cada um. Mas assim, não tem diferença hoje em dia, tanto em pós-produção, quanto em captação. O que faz diferença é o orçamento. Assim como no cinema você tem produções de grande porte, tem produções de menor porte, em televisão é a mesma coisa. Mas a gente chegou num momento que produzir áudio para cinema e produzir áudio para a TV, quando se fala em dramaturgia - em séries principalmente e em algumas novelas - a gente está falando da mesma coisa! Em termos de produção, o que muda é a linguagem.

- Retomando a questão do tempo de produção, em média qual é o tempo disponível para a pós-produção de som de um capítulo de telenovela?

Na média um dia. Só que divido em três etapas, seriam pessoas fazendo paralelamente: diálogos, efeitos e mixagem. Claro que têm projetos que você tem uma semana para fazer um primeiro capítulo, às vezes séries você tem mais um tempo. Mas novela são seis dias por semana, então você faz diariamente um capítulo.

\section{- No primeiro capítulo existe mais tempo do que nos capítulos intermediários?}

Geralmente sim, mas é imprevisível, porque tem muita remontagem. O primeiro capítulo dar-se a ideia de que se têm muito mais tempo, por causa de toda a pré-produção que aconteceu antes e uma edição também com mais tempo, mas como é a primeira conceituação é comum remontar e fazer um monte de cena no dia ou no mesmo prazo de um programa que já estivesse no ar. Então não dá pra dizer que: “ah, temos muito tempo pra fazer o primeiro 
capítulo e fica lindo e os outros não". Então não é verdade, porque muita coisa foi preparada antes, até de desenho sonoro mesmo: ambientes já captados, etc. Hoje a gente tem uma pessoa dedicada a isso, uma equipe que só grava os ambientes e efeitos. Então já preparou o material todo para o sonoplasta, aquilo ali vai fazer diferença até no final do produto, não quer dizer que só no primeiro capítulo que aquilo seja diferente. Você já vai pelo texto e pelos ambientes, as paisagens que precisam ser gravadas.

- Esse é um trabalho de pré-produção de som?

Pré e durante também, porque aparecem algumas demandas durante. Uma novela isso que é diferente de cinema - uma novela é um projeto muito longo, então ele vai sendo escrito durante a edição, é uma obra aberta. Então aparecem coisas que não estavam escritas, a gente tem que ter alguém participando das leituras. Tem demandas que aparecem depois da estreia. O próprio sonoplasta que é quem edita os efeitos: “caramba, isso aqui vai ser legal!" Tipo um carro de época que vai ser legal. Então tem coisas que aparecem que não eram previstas. Então é muito feito na pré-produção, mas tem muitas coisas feitas durante o andamento do processo.

\section{- Quais os parâmetros atuais para mixagem e finalização do som?}

Desde alguns anos, de 2010 talvez, principalmente depois que foi sancionada a lei do Loudness, a gente trabalha olhando mais para Loudness do que para pico. Isso é uma mudança significativa. Porque ao invés do que parece ser, ao invés de limitar tecnicamente o trabalho, isso faz com que a gente tenha mais range para trabalhar. Porque ficar mirando em um pico em $-10 \mathrm{~dB}$, você mirava só tecnicamente no nível do sinal e que não queria dizer nada. Um pico em $-10 \mathrm{~dB}$ pode ser um som alto como pode ser um som baixo. Então você parar de olhar para pico - só garantir que não vai distorcer, ou seja, um pico em -3dBFS na escala True Peak que ai entra amostra e em termos de volume geral, de intensidade sonora percebida, trabalhar com a média do bloco de -23LFS, que é o padrão de Loudness - a gente pode ter variações que a gente não tinha antes. A gente pode se dar ao luxo de ter uma cena em que vai ter um pico em -3LFS, muito acima de -23LFS, um acidente alguma coisa, e depois ter uma cena mais baixinha, só diálogo. Antes não, você só tinha que garantir que não ia passar de $-10 \mathrm{~dB}$, 
seja a cena alta ou a cena baixa. Agora não, desde que a média seja -23LFS e que essa média não varie muito, que é outro parâmetro chamado Loudness Range que não pode passar de 8 , não pode variar muito, não pode ter um dinâmica de cinema. Isso não pode, porque senão de noite o cara vai estar com a televisão ligada ali numa cena baixa e depois quando tiver um acidente ou uma explosão vai acordar o vizinho, vão reclamar, vão pegar o controle remoto toda hora. Então tem um limite para isso, mas mesmo assim artisticamente você pode brincar com a dinâmica, pode ter uma cena alta e uma cena baixa. Porque com o loudness você tem um parâmetro que não indica só quantitativamente um som, indica quantitativamente uma percepção de intensidade sonora subjetiva. Então é o volume que você ouve que está sendo medido ali. Isso ajuda muito e está em todos os parâmetros de padrões de entrega para exibição da emissora, e artisticamente veio com essa contribuição.

\section{Transcrição da entrevista realizada com Thanus Chalita, no dia 15 de dezembro de 2016.}

- Quais foram os impactos da implantação da estereofonia (em dois canais) nas telenovelas?

As músicas, os ruídos, que "passam" do right para o left, ou do left para o right. Certas coisas que quando você está vendo, por exemplo, uma porta que está no lado esquerdo, ai você "puxa" no estéreo mais para o lado esquerdo, ou um carro que passa de um lado para o outro, você consegue fazer estéreo. E a música que é feita em estéreo.

- E as vozes?

Às vezes sim, dependendo de quando você está olhando o monitor se a pessoa der um grito do lado esquerdo, ou um grito do lado direito você consegue fazer isso. Ou murmuro de vozes, por exemplo, em um bar que tenha uma galera falando do lado esquerdo, ou do lado direito, você faz essa parte em estéreo. Agora cara a coisas é tão corrida que às vezes a gente nem tem tempo de fazer isso. O normal da voz é central. 
- Atualmente, as telenovelas são mixadas em 5.1?

O 5.1 é um 5.1 meio fake, porque a gente usa um plugin. Porque as músicas não são feitas em 5.1, os ruídos é muito pouco gravado em 5.1, a gente tem muita coisa pra desenvolver ainda para fazer um 5.1 bom, tipo cinema. Eu estou achando que a TV Globo vai até tirar o 5.1, porque é meio fake, não é uma coisa real. A música não é feita em 5.1. A gente coloca um plugin e faz um upmix de tudo e manda em 5.1. Mas é tão corrido que a gente não tem nem tempo de revisar em 5.1, no caso das novelas neh!? Quando você tem tempo, que a gente começa a sonorizar hoje e vai ao ar daqui duas semanas, ai a coisa é mais bem feita, é mais devagar, você presta mais atenção nos efeitos, nessas coisas todas, você tem um capricho para fazer. Mas é meio fake. A gente usa um plugin que se transforma em 5.1.

- Quanto tempo em média você tem para realizar a sonoplastia de um capítulo de telenovela?

A novela é muito corrida, a gente tem um capítulo de frente de um dia só, dependendo de como esteja a novela. Não é igual ao cinema, que a gente tem muito tempo para fazer, para revisar, para refazer. É muito difícil isso, é muito corrido. 